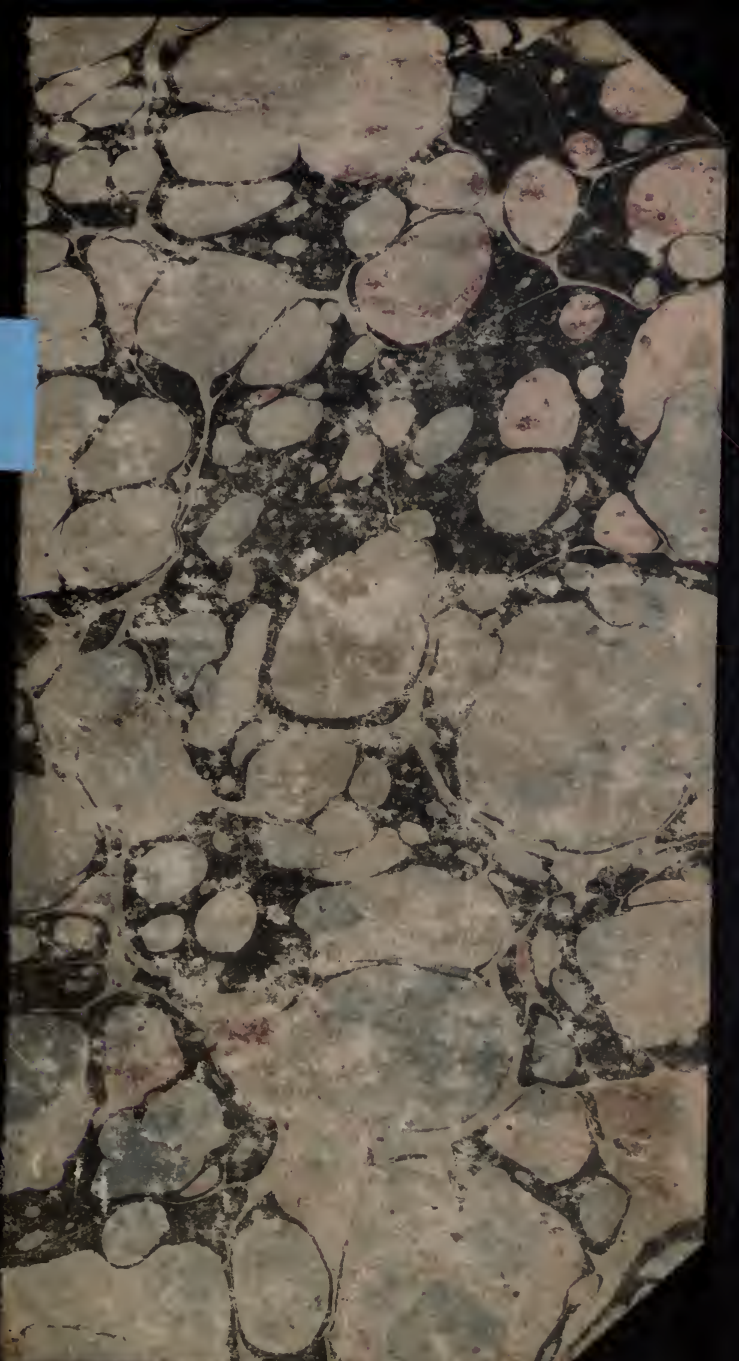




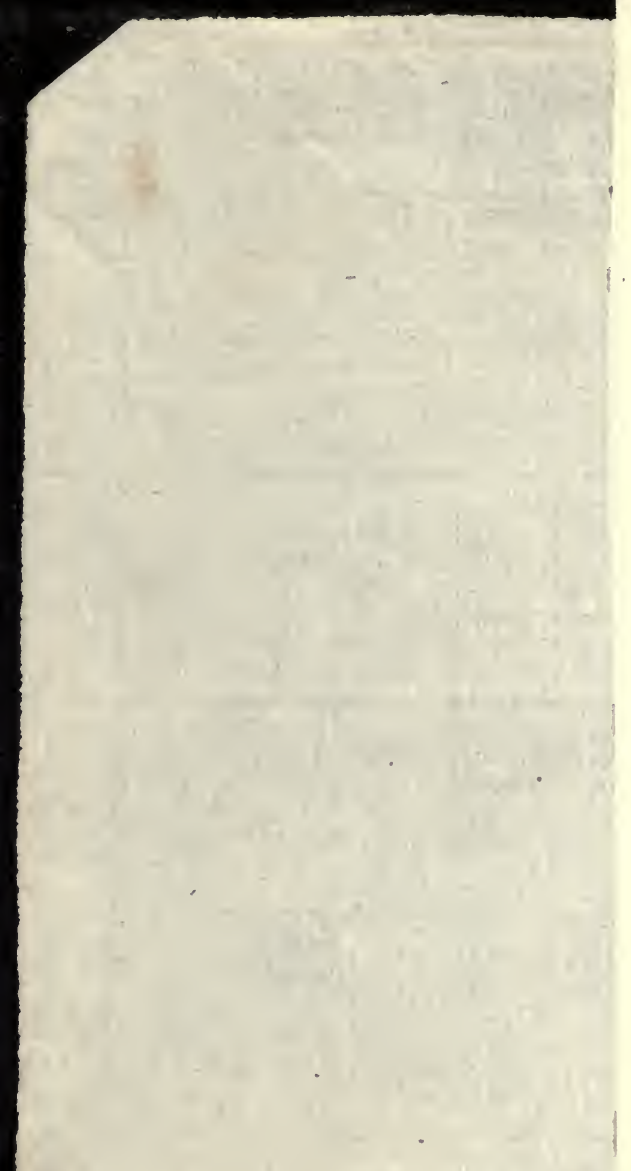




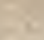

, 


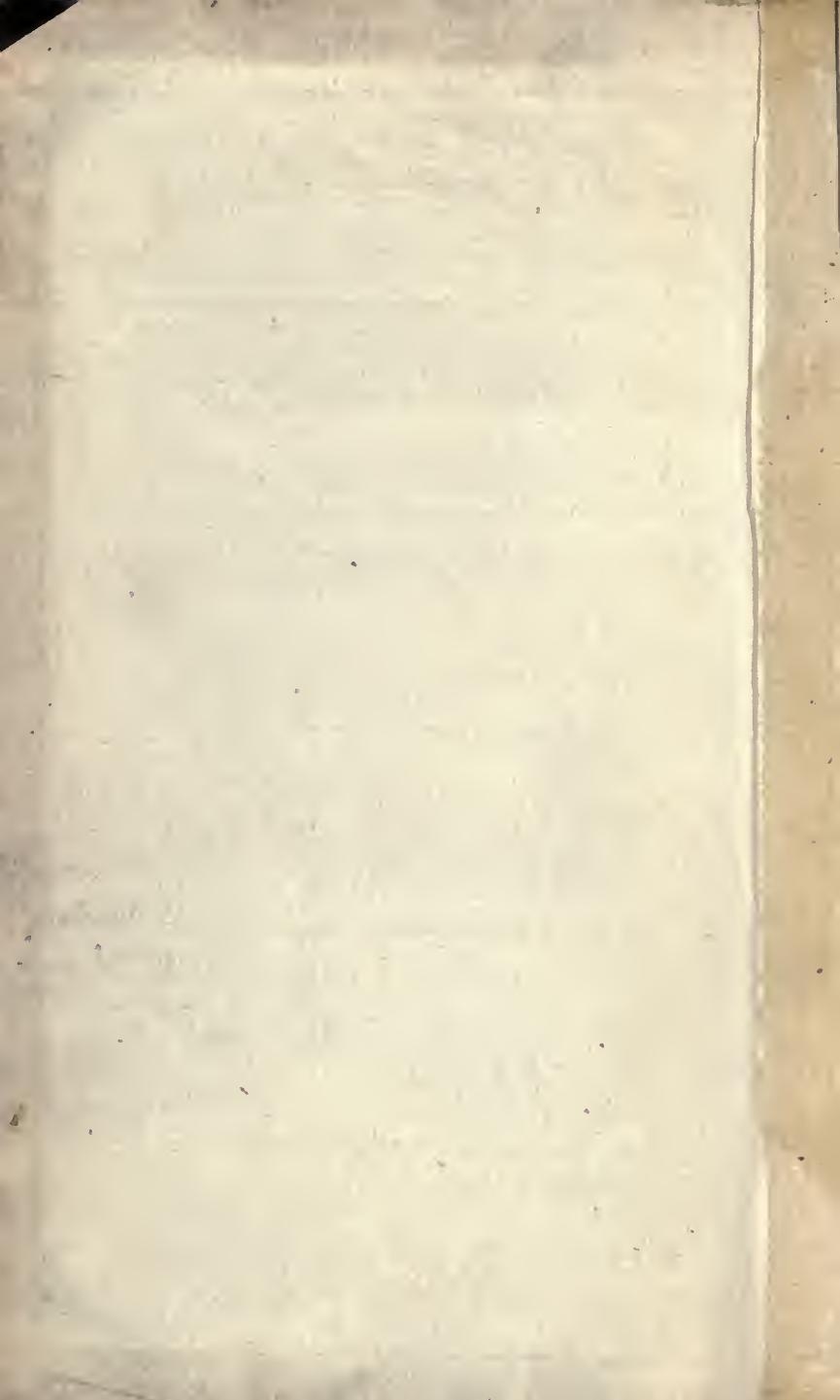




\title{
Aikin, John
}

THE

\section{WOODLAND COMPANION:}

OR

\author{
A BRIEF DESCRIPTION
}

OP

\section{BRITISH TREES.}

WITH SOME ACCOUNT OF THEIR USES.

\author{
ILLUSTRATED BY PLATES.
}

\section{COMPILED BY}
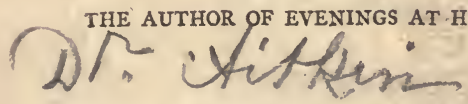

$3+a^{2}+2$

Welcome, ye thades! ye bowery thickets, hail $17760^{2}$

Ye lofty pines! ye venerable oaks!

Ye arhes wild, refounding o'er the fteep!

LONDON:

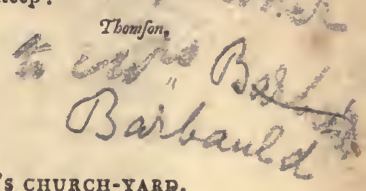

PRINTED FOR J. JOHNSON, ST. PAUL'S CHURCH-YARD,

BY TAYLOR AND WILKS, CHANCERYOLANE,

1802.

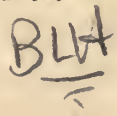




$$
\begin{aligned}
& \text { ATI }
\end{aligned}
$$

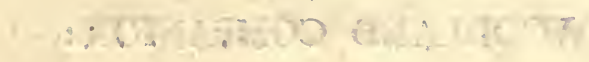

$$
\begin{aligned}
& -\quad-\infty
\end{aligned}
$$

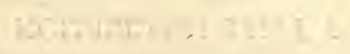

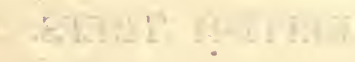

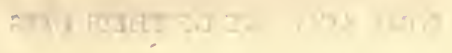

2

$15,+16$

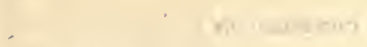

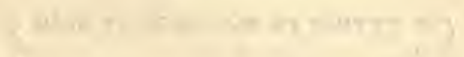

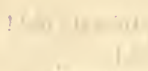

$\cdot+2+1$

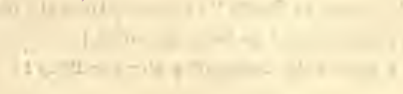




\section{ADVERTISEMENT.}

THE confined knowledge which young perfons, and even thofe of advanced age, are ufually found to poffefs of the noblest products of the vegetable creation, the trees which compofe our woods and decorate our parks and pleafure-grounds, fuggefted to the writer that a brief defcription of th $\mathrm{m}$, in the form of a pocket-companion of the rural walk, might be acceptable. - But as words alone would be inadequate to enable any one not an adept in botanical fcience to afcertain the feveral fpecies, he has added a fet of plates for illuftration, copied from the excellent figures fubjoined by Dr. Hunter to his valuable edition of Evelyn's Sylva. It will be feen that he has neglected thofe minute parts in the reprefentation which belong to the Linnæan Syfem, as it was his purpofe only to affift the common obferver in acquiring a vifual knowledge of each fubjęt. 


\section{CON'IENTS.}

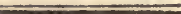

Page.

OAK, Pl. 1 .

Beech, Pl. 2.

Chesnut, $P l .3$.

Elm, Pl. 4.

Ash, Pl. 5.

Maple, Pl. 6.

Sycamore, $P l .7$.

Lime, $\mathrm{Pl} .8$.

Horse Chesnut, Pl. 9.

$-1$

Hornbeam, Pl. 10.

Hazel, Pl. 11.

Walnut, Pl. 12.

Wild Cherry, Pl. 13.

White-Beam, Pl. 14.

Wild Service, Pl. 15.

Hawthorn,

Quicken Tree, Pl. 16.

White Poplar, Pl. 17.

Black Poplar,

Asp or Aspen-Tree,

Oriental Plane, $P l .18$.

Occidental or Virginia Plane,

Birch, Pl. 19.

Alder, Pl. 20.

White Willow,

Crack Willow, Pl. 21

Weeping Willow,

Sallow,

Ozier,

Scotch Fir, Pl. 22.

Spruce Fir, Pl. 23.

Silver Fir, $P l .24$.

Weymouth Pine, Pl. 25.

Larch, Pl. 26.

Yew, Pl. 27.

Holly, Pl. 28.

Box,
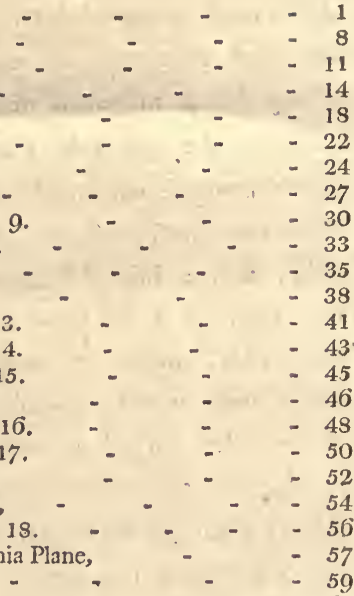

$-11$

$-14$

- 18

- 22

- 24

- 27

- 30

- 33

- 35

- 38

- 41

- 43.

- 45

- 46

- 48

- 50

- 52

- 54

- 56

-57
$-\quad 59$

- 59

- 62

- 64

- 66

- 67

- 69

- 71

- 73

- 78

$\begin{array}{r}-79 \\ \hline\end{array}$

- S1

- 83

- 55

- 88

- 91 


\section{THE}

\section{WOODLAND COMPANION.}

\section{THE OAK.}

\section{QUERCUS ROBUR.-Pl. 1.}

* Frucification. Barren flowers in a loofe catkin, each confifting of a bundle of chives, from 5 to 10 in the fame cup.

Fettile flowers in a bud on the fame tree, each having an oval feed-bud, which becomes an acorn.

Specific cbaracter. Leaves deciduous, oblong, broadeft towards the end, with tharp indentations and rather blunt angles.

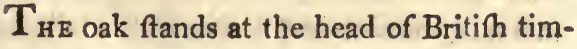
ber-trees, as well on account of its utility,

* In this, and all the future inftances, the fructification is defcriptive of the genus, or family, of the tree 
as of the grandeur and inajefty of its figure. It arrives at a bulk equal, if not fuperior, to that of any other tree of the foreft; and by the vaft arms which it throws out on every fide, it forms a mafs which fills the eye of the fpectator, and inpreffes him with gigantic ideas. Its rugged bark and jagged deep-green leaves add to its character of ruftic and mafculine frength.

The oak moft delights in a rich ftrong foil, in which it ftrikes its roots to a vaft depth. It loves hilly rather than boggy ground, and thrives beft in large plantations. 'It is injured by cropping; whence may be eftimated the mifchief annually done to this noble tree by the cuftom of cutting large branches for the celebration of the 29th of May. It forms the largeft head, and fpreads in the molt picturefque figure, when growing fingly, as in parks and ornamental grounds; but it rifes with a tall and

fraight

treated of, according to the Linnzan fyftem; the specific charader relates to the particular fpecies or kind which is the fubject of the article. 
ftraight trunk only in woods and clore plantations.

The ufes of the oak tree are very various, and comprehend almoft every part of it. The acorns (which, in common with the nuts of other timber-trees, bear the name of maft) are faid to have been one of the earlieft foods of mankind; and in lome of the warm climates they are ftill in ufe for that purpofe. - With us they are valued as the food of fwine, of which large droves are fent to fatten in the oak woods in this kingdom during fome weeks in autumn, when the ripe acorns begin to fall. Squirrels and other finall quadrupeds alfo partake of the repaft, and lay up acorns for their winter ftore.

Every part of the oak abounds in an aftringent juice, which is applied to various purpofes. The bark is particularly valuable on this account, which renders it the -chief material for tanning leather. Oaks growing in hedge-rows, which feldom arrive to the fize of timber-trees, owe great part of their

$$
\text { B } 2
$$

value 
value to their bark. Before it is ured, it is ground to powder; and the infufion of it in water is by the tanners termed ooze. The fmall twigs, and even the leaves of the oak may be applied to a fimilar purpofe. Galls, which are an excrefcence formed in the warm countries upon the leaves of a fpecies of oak, by means of an infect, are fome of the ftrongeft aftringents known, and are much ufed in dyeing, on account of their property of ftriking a deep black, with the addition of vitriol of iron. The oakapples, formed in the fame manner upon our trees, poffers a fimilar property, in a fmaller degree. Oak faw-duft is the principal material ufed in dyeing fuftians. It gives all the varieties of drab-colours and thades of brown, accordingly as it is managed and compounded.

But it is by the ufe of its wood that the oak has acquired its chief fame, and efpe. cially for the important purpofe of thip: building. This has made it fo peculiarly the favourite of England, to whore naval glory it is fuppofed materially to have contributed. 
tributed. Thus Pope, in his WindforForeft, fpeaking of vegetable treafures, fays,

Let India boaft her plants, nor envy we The weeping amber and the balmy tree, While by our oaks the precious loads are borne, And realms commanded which thofe trees adorn.

Oak-timber is fitted for this purpofe, by its ftrength and durability, and alfo by the property of not readily fplintering, a circumftance of much confequence fince the invention of cannon. Ships of war, therefore, if not entirely built of oak (which from the prefent fcarcity of that timber is feldom done) have always their fides planked with it. The crooked pieces of this wood procured from the bend of the branches are alfo ufed for the knees, by which the planks are held out and fupported. Oak-timber is likewife preferred for many other fervices of ftrength. In houfe-building it is ufed for door and window frames, and for wallplates. When more plentiful, floors and ftair-cafes were alfo made of it. In machinery, no other wood is equal to it where 
a great ftrefs is to be borne, as in mill-work, fteam engines, and the like. It is ufed for the bodies of carts and waggons, alfo for gates, pofts, and ladders. In the country it is a common material for furniture, fuch as tables, bedfteads, and chefts of drawers; its durability being thought a compenfation for the difficulty of working it. The coopers employ it for their largeft veffels, and for well-buckets and water-pails.

The oak may be termed not lers the poet's tree, than the artifan's. Some of the firft pocts, antient and modern, have chofen it as abject either of direct defcription, or of fimile; and that, not only in its flourifhing flate, but in its decay. Thus Lucan, in fome very fine lines, has made an aged oak the comparifon of Pompey the Great, at the time of his conteft for power with Cæfar, when, being little more than the Thadow of his former fame, he ftill excited awe by the remains of declining grandeur. Our Spenfer has given an original picture of the fame kind in the fable of the Oak 
and the Briar, in his Shepherd's Calendar, which, as being of true Englifh growth, I shall copy.

There grew an aged tree on the green,

A goodly oak fometime had it been,

With arms full ftrong and largely difplay'd,

But of their leaves they were difarray'd:

The body big and mightily pight,

Throughly rooted, and of wondrous height;

Whylom had been the king of the field, And mochel maft to the hurband did yield, And with his nuts larded many fwine; But now the gray mofs marred his rine, ? His bared boughs were beaten with ftorms, His top was bald and wafted with worms, His honour decay'd, his branches fere.

February.

A more exact vifible reprefentation of the fame object cannot be given, than by the figure of the old oak of Cowthorpe, Yorkfhire, which meafures fixteen yards in circumference within three feet of the ground, in Dr. Hunter's edition of Evelyn's Sylva. 


\section{(8)}

\section{THE BEECH.}

\section{Fagus Sylvatica. $-P l .2$.}

Fructification. Barren flowers in a kind of catkin, each confilting of about 12 chives in a cup. Fertile flowers on the fame tree, in a bud, changing into a hairy capfule with four valves and two feeds.

Specific cbaracter. Leaves oval, indiftinctly ferrated. Bark fmooth, white.

$T_{H E}$ beech is one of the moft ftately timber trees, and compofes large woods in fome parts of this country. It particularly delights in a chalky foil, where it will flourith and arrive at a great fize, though the land has all the appearance of barrennefs. When fanding fingly or at large diftances from other trees, it fpreads in a round form to a wide extent, and forms a deep mafs of

fhade; 
Thade; but when drawn up in clofe plantations, it rifes to a great height with fingular elegance ánd airiners. Its leaves are of a pleafant green, and many of them remain on the trees during winter, after turning brown. No verdure, however, will thrive beneath its made. The fmoothnefs of its bark has from antient times tempted the rural lover to carve the favourite name upon it; a cuftom recorded in various paftages of the poets; and the opcning of Virgil's firt Eclogue reprefents the mufing thepherd as reclining under the thade of a rpreading beech.

This is one of the glandiferous or maft. bearing trees. Its nuts, when caten raw, are apt to occafion giddinefs and head-ache, but, when thoroughly dried and powrlered, are faid to make wholefome bread. They are, however, chiefly the food of deer and fwine, and of fquirrels, dormice, and other fmall quadrupeds, which are numerous in the beechen woods. An oil expreffed from them is ufed in fome countries in place of buttcr. 
The wood of the beech is brittle, and apt to decay ; but, being eafily wrought, it is much ufed for various domeftic purpofes. The poets, who celebrate the fimplicity and frugality of the early ages, fpeak much of the beechen cups and bowls, fome of which received an extraordinary value from the hand of the carver. In our days, beech is a common material of the turner and cabinet-maker; the former ufing it for his larger ware; and the latter, for, common chairs and other articles of furniture. It is, indeed, almoft the only. Englifh wood employed by the London cabinet-makers. ' Its lightnefs caufes it to be chofen for the handles of tools; and it is fplit into thin fcales for band-boxes, fword-fcabbards, and the like. It is a common wood for fewel, and, in fome counties, is regularly grown in plantations for that purpofe. The dried lcaves of the beech make a very good ftuffing for mattreffes. 


\section{(II)}

\section{THE CHESNUT.}

\section{Fagus Castanea.-Pl. 3 .}

Fructification. As the beech.

Specific character. Leaves fpear-Phaped, with tharp ferratures; nakcd underneath.

$T_{\text {HIs tree is ufually called the Spanifb }}$ Cbefnut, as growing in the greateft perfection in Spain and others of the warm countries in Europe. Many, however, think it an original native of this inland; at leaft it arrives to the full bulk of a timber-tree in our woods and grovès. The appearance of an aged chefnut is ftriking and majeftic. It throws out arms equal in fize to thore of the oak, and they often fpring in an angular manner, and thwart each other, fo as to produce an uncommon effect. The deep furrows of the rugged trunk 
trunk fometimes form a kind of net-work by interlacing. The branches are richly clothed with long jagged leaves, of a pleafant green, and the head is maffy and fpreading. In autumn the leaves fade to a gold yellow, affording a very confpicuous variety of tinge in the woods. Few trees arrive at greater longevity. A chefnut at Tortworth, in Gloucefternhire, is proved to have ftood ever fince the year 1150 , and to have been then remarkable for its age and fize. The chefnut tree thrives in almoft all foils and fituations, though it fucceeds beft in rich loamy land. Nothing will grow beneath its thade.

Among the maft-bearing trees this may be reckoned the moft valuable, fince its nuts, by their fweet and farinaceous quality, are rendered good food for man, as well as for other animals. The chefnuts cultivated for their fruit are ufually grafted ones, called by the French marronier; and in many parts of the fouth of Europe they afford great part of the fuftenance of the poor, who make bread of their flour. They 
are alfo eaten as a delicacy at the beft tables, either roafted or ftewed. In this country the fruit of the chernut is fmall, and feldom comes to maturity ; it is therefore left to the hogs and fquirrels.

The wood of the chefnut is ftrong and durable, and is ufed for moft of the purpofes in which oak is employed. Some of the oldeft buildings in London are faid to be timbered with chefnut. The trunks, however, are often found decayed at the heart when they appear found externally; and the wood on working is apt to turn out brittle, and to feparate in roundifh maffes, which fault is termed being cup-foakey. It is preferable to any for making tubs and veffels to hold liquor, as not being liable to fhrink after being once feafoned. The principal ufe of chefnut wood among us is for hop-poles, of which it makes the ftraighteft, talleft, and moft durable. Being cut at an early age for this purpofe, it is rare to fee large chefnut trees in our woods; but they are frequent ornaments of our parks and pleafure-grounds. 


\section{(14)}

\section{THE ELM.}

\section{Ulmus Campestris.-Pl. 4 .}

Fructification. Flowers in clufters, each having about five chives, fucceeded by an oval bordered capfule, containing a fingle roundirh flattened feed.

Specific cbaracter. Leaves doubly ferrated, unequal at the bafe. Bark of the trunk cracked and wrinkled.

$T_{H E}$ common elm is a large timbertree of great beauty and ufe. It grows to a great height, and at the fame time, if permitted, throws out expanded arms, fo as to cover a large extent with its thade. Hence it is often planted fingly or a few to: gether in village greens, where it affords both a majeftic object, and a pleafant fummer thelter. The elm is however often feen trained to a vaft height with a fingle 
naked trunk, which mode of rearing deftroys its beauty, though it better fits it for a particular ufe. In this ftate it is very common in hedge-rows, efpecially in the neighbourhood of London. Elms are not frequent in woods or forefts, but are generally planted in avenues or in other artificial fituations. The diverfity in the form and fite of clms is agreeably iketched by Cowper, the poet, who, of all others, viewed natural objects with moft tafie and correctnefs. He firft mentions them as growing by the river's fide.

There, faft rooted in his bank

Stand, never overlooked, our favourite elms

That fcreen the herdfman's folitary hut.

Tafk, b. . .

Then they are feen encircling a cottage upon a hill.

'Tis perch'd upon the green-hill top, but clofe Environ'd with a ring of branching elms That overhang the thatch. Ib.

Next, they form a walk or avenue. The grove receives us next;

Between the upright thafts of whofe tall elms We may difcern the threfher at his tafk. 
- He alfo notices its hue, as of a deeper green than the anh.

The elm beft loves an open fituation and a black claycy foil. It bears tranfplantation well. It does not injure the grafs beneath it and its leaves are agreeable to cattle, and in fome countries conftitute a confiderable part of their food. The antients made great ufe of elms properly trimmed as props or fupports for their vines; and the poets frequently allude to the marriage of thefe diffimilar plants, and the aid derived to the weak and fruitful vine by twining round the ftrong ftem of her hufband elm.

The wood of the elm is hard and tough, and ufeful for a variety of purpores. It is particularly ferviceable for occafions which require its being kept conftantly wet; as in the keels and planking beneath the water-line of mips, mill-wheels and water works, and efpecially for water-pipes, the great demand for which is the caufe of its frequency about London, and of the prac- 
tice of training it without branches to a tall ftraight trunk, which may admit of boring in long pieces. It is likewife ufed for axle trees; naves, gate-pofts and rails, floors, dreffers, blocks, \&c. and it is very fit for the carved and ornamental works belonging to architecture.

There are feveral varieties of the elm, differing in the roughnefs and fmoothners of their leaves, and manner of growth. A dwarf kind is employed for making tall hedges or fcreens in gardens or nurfery, grounds.

A diftinct fpecies of elm, growing moftly in the North of England, and Scotland, is that called the Wych bazel (Ulmus montana) from the refemblance of its leaves to thofe of the hazel. It is fmaller and more branchy than the common elm; its boughs are more depending, and its leaves and feeds much bigger. 


\section{$(\cdot 18)$}

\section{THE ASH.}

Fraxinus Excelsior.-Pl. 5 .

Fructification. Flowers with chives and pointals upon fome trees, with pointals only upon others. Two chives in each flower. Seed-bud oval, compreffed, changing into a long $\mathrm{mem}-$ branaceous feed-veffel, containing a fingle feed.

Specific cbaracler. Leaves generally winged, confifting of four or five pair of finall ones, ferrated, with an odd one at the end.

$\mathrm{T}_{H E}$ an is a tall tree, having a light thin foliage, which gives it a graceful appearance, efpecially when contrafted with trees of greater mafs and depth of thade. It flourines moft in woods, but will alfo thrive well in good foils upon open ground. It runs its 
roots a great way near the furface; which quality, together with the deftructive property of its drippings, renders it injurious: to herbage, and ftill more to corn.". When growing-near water it fornetimes hangs down its boughs like the weeping willow. No tree is fo often met with in ruins and upon antient walls, probably on account of the readinefs with which its winged reeds are borne by the wind. It infinuates its roots far into the crevices of thefe old buildings, and thereby becomes an inftrument of the deftruction of what affords it fupport. In like manner it faftens upon loofe flaty rocks, and decorates them with its verdure. It is one of the lateft trees in coming into leaf, and lofes its leaves early in autumn. The bunches of long fkinny feeds, called keys, on the fertile trees, have a fingular appearance. It is obferved that while fome afh-trees bear great quantities of keys yearly, others feem never to bear any. The former, however, are naked of leaves and unfightly; whereas the latter abound in foliage, and are pleafing objects. The bark is fmooth c 2 
and light-coloured; the leaves dark green. A well-grown an is a bandfome and elegant object, though all may not agree with the Roman poet in giving it the prize of beauty above all the natives of the foreft. There are few which excel it in utility ; for its wood, next to that of the oak, is employed for the greateft variety of purpofes. Thus our Spenfer, mentioning the particular ufes of a number of trees; characterifes the afh as

\section{for nothing ill.}

It may be peculiarly termed the bufbandman's tree; for it is one of the principal materials in making ploughs, harrows, waggons, carts, and various other implements for ruftic ufe : hence a proportional number of afh-trees thould be planted in every farm. The toughners of its wood rendered it a favourite with the heroes of old for the thafts of their potent fpears; whence it is poetically termed "the martial afh." With us it is much employed in poles for various purpores, and alfo in fpokes 
fpokes of wheels, tool-handles, and the like. Dairy utenfils are moftly made of afh: - Its loppings make good fuel, and it has the quality of burning when frelh as well as dry, and alfo.with little fmoke. Its alhes afford good pot-anh. The bark of the an has an aftringent quality, and is ufed in tanning calf-1kin. Its leaves are eaten by cattle: 


\section{(22)}

\section{THE MAPLE.}

\section{ACER CAMPESTRE.-Pl. 6.}

Fructification. Flowers, fertile and barren upon the fame tree; the chives in both, eight in number. In the fertile, the feed-bud changes into two fapfules united at the bafe, and terminating above in large membranous wings, with a fingle feed in each. Specific character. Leaves lobed, blunt, notched.

$T$ He maple is a tree of no great figure, and with us chiefly grows in thickets and hedges as an underwood. It may, however, be trained to a confiderable height. Its wood is foft and fine-grained, and is cxcellent for the turner's ufe, who can bring it to an almoft tranfparent thinnefs. It excels beech for the purpofe of making ups, difhes, and the like; and is often mentioned 
mentioned by the poets as the material of thefe utenfils in ruftic and fimple life. The beautiful variegation of its knots, however, has given it value in ornamental works; and the antient Romans, for their luxury of curiouny-veined tables, prized the maple next to their famous citron-wood. Mufical infiruments are alfo frequently made of maple. This tree grows very full of branches, which, from the opportunity they give of the lodgment of the rain water, is probably the caufe of that difpofition to internal decay of which Spenfer accufes it ;

- the maple, feldom inward found.

Cowper defcribes it as

- glofly-leaved, and hining in the fun.

Its bark is furrowed and cork-like. 


\section{$(24)$}

\section{THE SYCAMORE.}

Acer Pseudo-Platanus. - Pl. $\%$

Fructification. As the Maple.

Specific cbaracter. Leaves with five lobes, unequally ferrated. Flowers in bunches.

THIs fpecies grows to a larger fize, and is more fightly than the common maple. The name Sycamore, (Wild Fig, ) is an improper one, and that of Greater or Broad-leaved Maple is more fuitable. The Latin appellation Pfeudo-Platanus (Falfe Plane) well expreffes its appearance. It is of quick growth, and flourifhes beft in open places and fandy ground. It is not uncommonly planted in ftreets, and before houfes, on account of its thade. It has alfo the property of being lefs injured by the neighbourhood 
bourhood of the fea, and the dalhing of the falt fpray, than almoft any other tree; and hence is often fet in rope-walks in maritime towns. It comes early into flower, and ufually bears a vaft profufion of pendent light-green bunches or catkins, which make a handfome fhow. The flowers fmell ftrong of honey, and afford much pafture to the bees. The foliage of the fycamore foon lofes its fpring verdure, and changes its hue. Cowper calls it

- capricious in attire,

Now green, now tawny, and, ere autumn yet

Have changed the woods, in fcarlet honours bright.

Its wood is foft and very white, and hence proper for the ufe of the turner, who makes from it bowls, trenchers, and other utenfils. From its lightnefs, it is alfo occafionally ufed for cart and plough timber.

If the fycamore is tapped in the fpring, it affords a fweetin watery liquor which may be ufed to fave malt in brewing, and will yield a fugar upon infpiffation. Moft 
of the fpecies of the maple, indeed, afford fweet juices; but none fo remarkably as the fugar-maple, which is a very common native tree in North America, and from which large quantities of coarfe fugar are made by the fettlers in the inland parts. 


\section{$(27)$}

\section{THE LIME.}

Tilia Europea.-Pl. 8.

Fructification. Flowers with five petals and many chives; the feed-bud turning to a dry berry, or capfule, having five cells with a fingle feed in each. Generally, only one feed comes to perfection, purhing afide the reft. Specific cbaracter. Flowers witbout a nectary, whitifh. Leaves heart-Thaped, ferrated. A floral leaf to each bunch of blofioms.

$T_{H E}$ lime or linden is one of the beauties among trees, and is rather cultivated on that account than for its utility. It grows ftraight and taper, with a finooth erect trunk, and a fine fpreading head inclined to a conical form. Its leaf is large, and its bark fmooth. In a good foil it arrives at a great height and fize, and 
becomes a ftately object. But it is feldom viewed fingle, and its chief glory arifes from fociety. No tree is fo much employed for avenues, and for bordering ftreets and roads: Some of the ftraight walks of antient limes, which modern tafte has hitherto fpared, are beautiful specimens of the pointed arch made by the interfection of branches, which has been fuppofed tobe imitated in the Gothic architecture of cathedrals. In viewing one of thefe noble works of nature difciplined by art, who will not exclaim with Cowper,

Ye fallen avenues! once more I mourn Your fate unmerited, once more rejoice That yet a remnant of your race furvives. How airy and how light the graceful arcl, Yet awfulas the confecrated roof Re-echoing pious anthems! while beneath The chequered earth feems reftlefs asa flood Brufhed by the wind.

Tafk, b. 1.

The lime comes early into leaf, and its verdure is one of the firft harbingers of fpring beheld in great towns, where it often decorates the fquares and public walks. Its flowers are highly fragrant, and are very 5. attractive 
attractive to the bees, which gather much honey from them. An infufion of them is faid to make a pleafant tea. The fap of the tree contains fugar. Lime wood is foft and light, and therefore only fit for ufes requiring little ftrength. It is ufed by thoemakers and leather-cutters to cut leather upon, as not being liable to turn the edge of their knives. The clofenefs of its grain, joined with foftnefs, and the property of not being readily attacked by the worm, has caufed it to be chofen by carvers for the rich ornamental work with which churches and palaces were formerly decorated. Mr. Evelyn mentions it as the material employed by the celebrated artift Gibbon for his beautiful feftoons and other fculptures. It makes good charcoal for defigners. Its inner, bark, foaked in water, yields a fibrous matter fit for ropes and fifhing-nets. The Rufia mats, and the bark fhoes of the peafants, are made of this material. 


\section{$\left(3^{\circ}\right)$}

\section{THE HORSE CHESNUT.}

Asculus Hippocastanum.-Pl.g.

Fructification. Flowers in a long fpike, each having five petals, feven chives, and one pointal : feed-bud changing into a fpinous capfule of three cells, with two feeds in each, fome of which are abortive.

Specific cbaracter. Leaves blunt - fpearthaped, ferrated, growing by fevens on one ftalk, the middle one largeft.

THIs tree, which is originally a native of the Eaft, has not very long been naturalized in England. Its introduction here has been folely owing to its beauty, in which, at the flowering feafon, if certainly excels every other tree of its bulk that bears our climate. In early fpring it puts forth large buds, which burft into verdure 
dure among the firft greens that enliven the year, ; and its ample palmated leaves have an appearance both uncommon and handfome. Not long after, it puts forth its long upright spikes of white and variegated flowers, generally in fuch number as to cover the whole tree, and give it the refemblance of one gigantic bouquet. No flowering thrub is rendered more gay by its bloffoms than this tall tree; hence it combines beauty with grandeur, in a . degree fuperior to any other vegretable of thefe climates. The head is alfo thapely and regular in its growth, and well adapted to the fymmetry required in walks and avenues. It has the defect of changing and lofing its leaves early in autumn, the natural confequence of its early fpring verdure. It is alfo accufed of not well refifting tempeftuous winds. The wood of the horfe chefnut is of little value; it is, however, of fome ufe to the turner. Its fruit or nuts are of a farinaceous quality, but fo bitter as to be unfit for human food. Deer are faid to be fond of them, and theep will eat them; and when boiled, they 
they have been ufed to fatten poultry. When left to decay they turn into a kind of gelly, which has been employed Jike foap in wathing linen. The bark has confiderable aftringency, and may be employed for tanning leather. 


\section{$\left(33^{3}\right)$}

\section{THE HORNBEAM.}

Carpinús Betulus. $-P l .10$.

Fructification. Barren and fertile flowers in catkins upon the fame tree. The barren, with from eight to fixteen chives in each : the fertile, with two feedbuds each, changing into nuts.

Specific cbaracier. Leaves oval, pointed, fharply ferrated. Bark fmooth, white.

THE hornbeam is not commonly found as a timber-tree, though it may be reared for this purpofe, and will grow to a great height, with a fine ftraight trunk. It thrives well upon a cold ftiff clay, on the fides of hills, bears lopping and tranfplanting, and is capable of refitting the wind. It is, however, principally cultivated as a fhrub and underwood, and is excellent for forming tall hedges or fcreens in nurfery-

$$
\text { D. }
$$$$
\text { grounds }
$$ 
grounds or ornamental gardens. It is of quick growth, and has a gloffy verdure which is very pleafing to the eye. It keeps its leaves long, and even all the winter when fheltered. The wood of the hornbeam is very white, tough, and ftrong. It is ufed for yokes, handles for tools, and cogs for mill-wheels, and is much valued by the turner. The wood is very inflammable, and will burn like a candle, for which purpofe it was antiently employed. The inner bark is much ufed in the North of Europe for dyeing yellow. 


\section{THE HAZEL.}

Corylus Avellana,-Pl. 11.

Fructification. Barren flowers in a long fcaly catkin, each flower of eight chives. Fertile flowers on the fame tree in buds, diftant, each flower with two fhafts, the feed-bud changing to a nut.

Specific cbaracter. Leaves oval, ferrated, wrinkled; props or ftipulæe oval, blunt.

Thovg H the hazel does not arrive at the bulk of a timber-tree, it is on feveral accounts worth notice among the natives of the foreft. Its male catkins, of a yellowinh green, are among the firft appearances in the year of vegetable expanfion, generally unfolding in the month of January. Its fruit-bearing buds make a beautiful thow 
in March, when they burft, and difclofe the bright crimfon of their Thafts. The hazel is met with native in almoft every part of this inland, forming hedges or coppices, and thickening the approaches of woods. If fuffered to attain their full growth, they fhoot into poles of twenty fect in length; but they are ufually cut down fooner, in order to form walkingfticks, finhing-rods, ftakes, hurdles, and the like, or for burning into charcoal. Hazel-charcoal is preferred to any other by painters and engravers ${ }_{2}$ for the freedom with which it draws, and the readiners with which its marks can be rubbed out.' The nuts of the hazel are a generally agreeable fruit. They abound in a mild oil, which may be extracted by expreffion, and is ufed by painters for mixing with their colours. Nuts, however, are difficult of digeftion, and, when eaten in large quantities, often prove hurtful. They ripen foon aftcr. harveft; and Thomfon gives an animated picture of the amufement of gathering them, ufually termed nutting. 
Ye fwains, now haften to the hazel-bank, Where, down yon dale, the wildly-winding brook Falls hoarfe from fteep to fteep. In clofe array, Fit for the thickets and the tangling thrub, Ye virgins, come. For you their lateft fong The woodlands raife; the cluftering nuts for you The lover finds amid the fecret thade; And, where they burnilh on the topmott bough, With active vigour cruthes down the tree, Or thakes them ripe fróm the refigning hufk.

Autumn.

They are a favourite food of fquirrels, which lay them up in their winter hoards, and always take care to pick out the beft. It is a common obfervation, that a plentiful year for nuts is the fame for wheat.

The filbert is a variety of the common nut, diftinguifhed by a longer fruit, and a thinner 1kin. It is cultivated in plantations in the Kentifh orchards, and yields a valuable product. 


\section{THE W.ALNUT. \\ Juglans Regia. - Pl. 12.}

Fructification. Barren flowers in an oblong catkin, each flower having many chives. Fertile flowers upon the fame tree, growing by twos or threes, each fucceeded by a large .round flefhy: capfule containing one nut.

Specific character. Leaves fmall, oval, fmooth, equal, fet in pairs, with an. odd one at the end.

$T_{H E}$ walnut, though not a native of our woods, is in many parts planted fo freely; and fo well perfećts its fruit and timber, that it may be confidered as fairly naturalized among us. It loves a rich loamy foil, but will grow well on ftony ground, if the ftaple be chalk : hence it is found to thrive on the chalky downs of Surrey, where 
where large plantations of it have been made. The tree arrives at a refpectable fize, and makes a good figure either fet in row's or growing fingly, though it has the defcet of getting its leaves very late, and Thedding them early.

As a timber-tree the walnut was formerly in greater requelt than at prefent; when its place is moftly fupplied by foreign woods. I las been much ufed by cabinet-makers for bedfteads, chairs, tables, and bureaus, for which purpofes it is one of the moft durable woods of Englih growth; alfo for wainfcots, and ftocks for guns. The wood near the root is often beautifully veined, and fit for inlaying and ornamental works. The black Virginia walnut, however, excels our own for thefe ufes. It is for the fake of the fruit that the walnut is chiefly cultivated among us. This is one of the molt grateful of the nut kind, and forms a welcome addition to derferts at all tables as long as it continues freth and moirt. It contains much orl, which, like that of the common nut, may be feparated 
rated by expreffion, and is ufed by painters and varnithers, and, in fome countries, alfo fo: food, inftead of butter. The unripe walnuts, with their green flefhy coat upon ther $h$, are commoniz ufed as a pickle. A fyrup made with them is a vuigar medicine againft worms; and decoctions of the hufks and leaves, wbich are ttrongly bitter and aromatic, are fornetimes poured upon walks and grafs plots in order to kill the earthworms and grubs.

Thofe fingular vagrants, called Gipfies, ftain their fkins of a tawny hue with the juice of green walnut hufks. 


\section{And $(4 \mathrm{I})$}

\section{THE WILD CHERRY.}

\section{Prunus Cerasus.-Pl. 13.}

Fructification. Flowers with five petals, from twenty to thirty chives, and one pointal : feed-bud changing to a pulpy fruit, containing one nut or ftone.

Specific cbaracter. Umbels of flowers on hort foot-ftalks : leaves oval-pointed, ferrated, fmooth, often doubled together.

Thovgr the wild black cherry is not a common tree in our woods, yet it may claim the rank of a native, fince it is met with in feveral counties, of a large fize, and propagates itfelf. Young plants of it are often found within the hollow trunks of old willows, into which the ftones have 
been dropt by birds. Its appearance in fpring, when covered with white bloffoms, is very beautiful : hence it makes a pleafing ornament in parks and pleafure-grounds, and forms an agreeable varicty among ther tall trees, few of which make any fhow with their flowers. It thrives well in light poor land, andparticularly loves a fandy foil and elevated fituation. The fruit, though fmall, is pleafant to the tafte, and gives a fine flavour-to fpirits. The wood is hard and tough : it is much valued for hoops of cakks; and is alfo ufed by the turner and cabinet-maker, and is ftained. fo as to refemble mahogany: It makes excellent focks for cngrafting the garden cherries upon; being, indeed, the original of all the cultivated forts, The gum which exudes from it is equal in its properties to gum-arabic. 


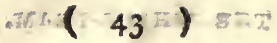

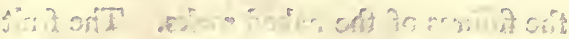

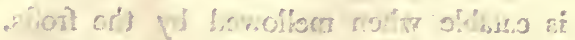

THE WHITE-BEAM.

Cratergus Aria.- $P l .14$.

Fructification. Flowers with five petals, about twenty chives, and two pointals, fucceeded by a round berry containing two or four feeds.

Specific cbaracter. Leaves oval, unequally or doubly ferrated, woolly on the under-fide.

THrs tree has a general whitenefs or mealinefs in its appearance, which has given it its name. It grows to a moderate fize, and loves dry and open fituations. It is found on the chalky hills of Kent, Surrey, and Suffex, and alfo in the mountainous parts of Derbymire, where it thoots from 
44 THE WHITE-BEAM。

the fiffures of the naked rocks. The fruit is eatable when mellowed by the frofts. The wood is tough, hard, and fmooth, and is fit for axles, wheels, walking-fticks, and tool-handles.

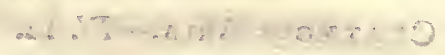




\section{( 45$)$}

\section{THE WILD SERVICE OF SORB.}

\section{Crategus Torminalis.- $P l .15$.}

Frucification. As the former.

Specific cbaracter. Leaveș with feven angles, the lowermoft lobes ftanding wide.

THis fpecies, alfo called the Maple-leaved Service, grows in various parts of England, chiefly upon ftrong foils. In Hertfordhire large trees of it are met with. Its fruit ripens late in autumn, and is then brown; and if kept till foft acquires an agreeable acid tafte, and is eaten; though from the Latin trivial name of torminalis, (griping,) it be concluded that it is not very favourable to the bowels. Few of the native fruits of this climate can boaft of a much fuperior quality. 


\section{$(46)$}

\section{THE HAWTHORN.}

\section{Crategus Oxyacantha.}

(MoNogyna of Withering.)

Of this well known fpecies, called alfo the White-thorn, it is unneceffary to fay. more by way of defcription, than that it is diftinguilhed from the reft by its trifid leaves, and by its flowers having but a fingle pointal. Its fruit, the haw, is like that of the two former kinds, but fmaller.

Although the hawthorn is rather a fhrub than a tree, it well deferves notice among our forefters. From the clofenefs of its growth, and its furniture of Tharp thorns, it is univerfally preferred for making live fences or quick hedges; and the pecufitar richnefs of the extenfive profpeets in England is much owing to the frequency of the enclofures made by this plant, which affords a de- 
a delightful verdure. Its flowers, likewife by the name of May, decorate that month particularly, with a profufion of beauty united with fragrance. Its fcarlet berries greatly contribute to enliven the winter. The hawthorn, planted fingly, acquires a refpectable fize, and is a fine object in the flowering feafon. Its wood is tough and ftrong, and is fit for axle-trees and toolhandles. 


\section{$\left(4^{8}\right)=1$}

\section{THE QUICKEN TREE.}

Sorbus Aucuparia. - Pl. ID.

Frucification. Flowers with five petals; about twenty chives; and three pointals; fucceeded by a round berry with three feeds.

Specific cbaracler. Leavès winged; feven or eight pair of fmall ones, fpearfhaped, ferrated, with an odd one at the end. Flowers white, in large bunches. Berries foft, red.

THrs tree is better known by the name of the Mountain $A / B$; and in the north of England by that of the Rowan-Tree. It is properly a fpecies of the fervice or forb. In the fouthern counties it is generally regarded as a fhrub or underwood; but in the north, where it is permitted to grow at pleafure, 
pleafure, it arrives at a confiderable fize. It is chiefly valued as an ornamental addition to plantations, on account of the elegant lightnefs of its foliage, and the beauty of its red berries, which remain on the tree during the whole winter. It will thrive in any good foil, but delights moft in a hilly fituation. The wood is tough and folid, and is valued by the whecl-wright and tool. maker. When bows were in ufe, it was regarded as next to the yew for making thofe weapons. The berries will make a fermented liquor, and are fometimes added to malt in brewing. When dried and powdered, they afford a kind of wholefome bread. Thrumes are exceedingly fond of them; and in hard winters refort in numbers to the quicken trees, from which they can fcarcely be driven away. When the fuperftitious belief in witchcraft prevailed, the wood of this tree was fuppofed to be a prefervative againft its effects. 


\section{$-150)$}

\section{THE WHITE POPLAR, or ABELE.}

\section{Populus Alba.-Pl. 17.}

Fructification. Male and female flowers upon feparate trees. The male in an oblong catkin, each flower without petals, and confifting of eight chives. The female, in a catkin, without petals, having a feed-bud changing into an uval capfule, which contains feveral fmall feathered feeds.

Specific cbaracter. Leaves rounded at the bafe, tapering to a point, angularly indented, blackifh green above, covered with a thick cottony down beneath.

Tuls tree, which grows in woods and hedge-rows, and efpecially in low moift fituations, is very confpicuous from the whiteners of its foliage. 
The poplar, that with filver lines his leaf.

It is a quick grower, and bears cropping well, but its thade is unfavourable to pafturage. The wood is foft and white, and is ufed for floors, laths, and packing-boxes. 


\section{THE BLACK POPLAR.}

\section{PopUlus NigRa.}

Frullification. As the former.

Specific cbaracter. Leaves trowel-hhaped, ferrated.

' $\Gamma_{H E}$ name of black feems given to this fpecies of poplar only in diftinction from the wbite; for its leaves are a pleafant green, and the tree has nothing dark in its appearance. The leaves are fmaller than thofe of the preceding, and more angular. The tree arrives at a greater fize, and is, indeed, one of the talleft and moft ftately to be feen, when arrived at full growth. It loves a rich foil in a moift fituation, as the banks of rivers and the borders of meadows. It is a frequent tree in Lancahire and Chehire, where the long rows of poplars 
almoft conceal from view the low-feated towns and villages. From its great fize, boards are fawn from it very fit for flooring, which have the ufeful property of fmothering rather than flaming, when a lighted coal falls upon them. The wood likewife is not apt to fplinter. The bark is light like cork, and ferves to buoy up filhermen's nets. Red fubftances like chetries are fometimes found on the leaves, which are occafioned by the puncture of an infect. 
a $\quad \operatorname{Ans}(-54-)=\cdots$

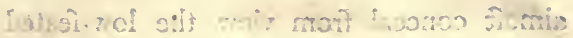

\section{THE ASP or ASPEN-TREE.}

\section{Populus TREMULA.}

Fructification. As the preceding. Specific cbaracter. Roundin leaves, angularly indented, and finooth on both fides.

TH $\mathrm{I}$ s fpecies is remarkable for the conftant tremulous motion of the leaves with the lighteft breeze, which is owing to the length and nendernefs of their foot-ftalks. The leaves are fmaller than thofe of the laft fpecies. The tree is large, and grows freely in all fituations. It is injurious to grafs; and its roots fpread fo near the ground, throwing out numerous thoots, that they fuffer nothing clfe to grow near it. The wood is extremely light, white and foft. Beavers are particularly fond of its bark and young thoots. 
Several foreign kinds of poplar flourifh well with us, and are introduced into plantations. The Po or Lombardy poplar has lately become a great favourite from its quick growth, and the eafe with which it is reared in all fituations. It is particularly planted in ftreets and roads for the purpofe of a fcreen; and on the borders of nurferygrounds, to fhelter other plants. It grows in a very regular tapering form, its numerous branches fpiring upwards into a cone. It makes a handfome figure in full foliage, but has too much of a broom-like appearance in the winter. 


$$
(56)
$$

\section{THE ORIENTAL PLANE.}

\section{Platanus Orientalis. $-P l .18$.}

Fruclification. Male flowers very minute, in globular catkins. Female flowers,

$\therefore \quad$ on the fame tree, in fimilar catkins, changing into balls of feeds, two or three often ftrung upon one ftalk, and hanging downwards.

Specific character. Leaves palmated. 


\section{$.058=(257)$}

\section{THE OCCIDENTAL or VIR- GINIA PLANE.}

Platanus Occidentalis.

Fruclification. As the former.

Specific character. Leaves lobed.

$T_{H E}$ plane trees, as might be inferred from their trivial names, are foreigners, and ftill rather the cultivated growth of our parks and gardens, than the fpontaneous product of our woods. They are chiefly valued for their beauty, and the luxuriance of their thade. The oriental kind, originally a native of the warm climates of Afia, was in prodigious eftimation with the antients, as affording in the highelt perfection that verdant canopy which is fo grateful to thofe who enjoy the open air in the heats of fummer. It was confecrated 
as well to the refrefhment of the philoropher in his academic groves, as to the pleafure of the bacchanalian, who held his revels under its Thade, and with appropriate gratitude fed its roots with wine. In thofe countries it grows to be one of the talleft and moft fpreading of trees. With us it feldom arrives at a capital fize, though the fmoothners of its trunk, and fullners of its large leaves, render it a ftriking and confpicuous object. The occidental plane is a native of North Ameriça, and is the moft common here of the two. Both fpecies delight in a moift fituation, and are quick growers. They greatly refemble each other, the difference being chiefly in the leaf, which in the oriental is palmated or fingered like the hand, in the occidental is divided into lobes... They have the property of annually throwing off their bark in fcales. 


\section{( $59=$}

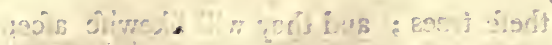

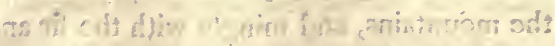
THE BIRCH.

Betula Alba.-Pl. 19.

Frucfification.: Barren flowers in a fcaly catkin, each containing four chives. Fertile flowers, on the fame tree, in a fcaly catkin, each fucceeded by a fingle feed.

Specific charadter. Leaves oval, tapering to a point, ferrated. Bark white.

$T_{\text {HIS }}$ is a tree of rather humble growth, but valuable for cloathing foils which are deferted by almoft all other trees. Thefe are the bogs and moffes, frequent in fome parts of this kingdom, and fill more in fome countries of the North, as Sweden, Norway, and Lapland. The watery parts of forcfts which fearcely produce any grafs, are often covered with a thick growth of

thefe 
thefe trees; and they will likewife afcend the mountains, and mingle with the fir and mountain-afh. A tourift in Wales fpeaks with much admiration of the light, airy, pendent birch, which occupies the higheft parts of the hills, and melters the cottages that dimly appear through its foliage. Its white bark contrafts with the black furface of the peat-mofes, and enlivens fcenes otherwife the moft gloomy and defolate in nature. The leaves are fmall and elegant; the boughs finely divided into flender twigs. They are fubject to a kind of difeafe, occafioning the branches to throw out a vaft number of fuckers, in one part, which intermix fo as to form a clofe refemblance of a rook's neft.

The wood of the birch is of little value, and, except for fuel, is fcarcely ufed but for hoops and women's thoe-heels. In the times of archery it was employed for arrows. "'The birch for fhafts," fays our Spenfer. On account of its lightnefs, it is much employed for fcaffoldings about London. Its finall branches or twigs are commonly ufed for 
for befoms. The bark is a very valuable fubftance to the northern people, who make various utenfils of it, and cover their houfes with it. It atfo makes good torches; for it abounds in a refinous quality, which likewife gives it firmners and durability.

The fap of the birch is an agreeablyflavoured, fweetifh liquor, well known as the bafis of one of our domeftic wines. It is, however, neceffary to add fugar or honey in order to bring it to ferment properly. This juice is extracted by boring holes in the tree almoit to the centre of the trunk, in the fpring, as foon as the fap begins to flow. The leaves of the birch pofferf an agrecable fragrance. 
2) $\quad(62=$

THE ALDER.

Betula Alnus.-Pl: 20.

Fructification. As the birch, except that the female catkin is rounder, like a fir-cone.

Specific cbaracter. Fruit-ftalks branched. Leaves nearly circular, ferrated, clammy.

$T_{H I S}$ tree is alfo a lover of moifture, and flourithes in boggy fituations, and by the fide of rivers. It may be reared to a large tree; in which ftate it muft have been, in order to have afforded the firft material for boats or canoes by its hollowed trunk, as mentioned by Virgil in his Georgics. With us it is more commonly planted for coppicewood, to be cut down every ninth or tenth year for poles. The wood is chiefly valuable 
luable for its property of remaining long found under water; whence it is ufed for water-pipes, and for piles to be driven into the ground in order to fupport buildings in boggy fituations. It is alfo employed for Thoe-heels, clogs, and turner's work. Every part of the alder has an aftringent quality. Its bark gives a brown dye, and is ufed by fifhermen to ftain their nets. With the addition of copperas it ftrikes a black. 


\section{$(64)$}

\section{THE WHITE WILLOW.}

\section{SALIX ALBA.}

Fruclification.-Barren flowers in a tiled catkin, each having. from two to five chives. Fertile flowers upon feparate trees, in a catkin, each fucceeded by a capfule of one cell, containing feveral feathered feeds.

Specific cbaracter. Leaves fpear-fhaped, marp-pointed, ferrated, downy on both fides, the lowermoft ferratures glandular.

$T_{H E}$ numerous willow tribe are for the moft part aquatics. They differ much as to fize; but are in general diftinguifhed by the length of their leaves, and flendernefs and flexibility of their branches. The white willow is one of thofe which arrive at it... 
the largeft bulk. It is common in moift woods and hedges, and on the fide of brooks and rivers, the courfe of which it often marks by its grey foliage, diftinguifhable at a diftance by the eye of the traveller. The wood of this tree is very white, and takes a fine polifh; whence it is in requelt for milkpails and other utenfils which require peculiar cleanlinefs. The bark of this and of fome other fpecies of willow is aftringent, and will tan leather. It has been ufed medicinally as a fubftitute for the Peruvian bark in the cure of agues; a property happily fuited to the fituations in which thefe trees principally delight. 


\section{THE CRACK WILLOW.}

\section{SaLix Fragilis. $-P l, 21$.}

Fructification. As the former.

Specific character: Leaves oval-lanceolate, ferrated, fmooth, with toothed, glandular foot-ftalks.

Thus fpecies alfo grows to a pretty tall tree. Its name is derived from the brittle. nefs of its branches, which, if ftruck with the finger, break off at the year's hoot. It grows quickly, and will thrive in moft foils. Its leaves are of a hining green on both fides, and of great length ; which give it an elegant appearance. 


\section{THE WEEPING WILLOW.}

\section{Salix Babylonica.}

Fructification. As the former.

Specific cbaracier. Leaves narrow-Spearfhaped, fmooth, ferrated; branches pendulous.

This fpecies is well known to the lovers of picturefque beauty, from that difpofition to hang down in long nender branches, which makes it an admirable accompaniment to a ftill retired piece of water, with the melancholy character of which it is perfectly in unifon. In mifty weather, drops of water are feen diftilling from the extremities of its branches ; which circumftance has given it a name, and wonderfully aids its effect. 'The weeping willow grows to a large fize, and attains a confiF 2 derable 
derable age. One has lately been cut down, planted in his own garden by the hand of Pope, and faid to have been one of the firf of its fpecies introduced into the kingdom. 


\section{$(69)$}

\section{THE SALLOW.}

\section{SALIX CAPREA.}

Fructification. As the former.

specific character. Leaves oval, wrinkled, downy beneath, waved, indented towards the upper end.

$T_{H 1 S}$ fpecies alfo grows to a confiderable fize. It delights in dryer foils than molt of the willow tribe, and will thrive on the tops of hills. Its branches are brittle, fmooth, and of a dark green. The catkins are very large and white, and much reforted to by bees early in the fpring. The flowering branches are gathered by children under the name of palms; and carried about on Palm-Sunday. The wood of the fallow is ufed for fuel, and makes excel- 
lent charcoal for gunpowder and drawingpencils. It is alfo employed by turners; and of the fmaller boughs hurdles are made. The bark is ufed by fome northern people in tanning. 


\section{$.71)$}

\section{THE OZIER.}

\section{Salix Viminalis.}

Fructification. As the former.

Specific cbarazler. Leaves very long, narrow; pointed, almoft entire, filky beneath; branches rod-like.

THIs fpecies is the principal example of the fhrub-willows, remarkable for their very long and flexible branches, which fit them for being woven into the different kinds of bafket-work. The ozier loves a moitt fituation, and is commonly planted by the fides of rivers and ponds. It covers many of the river-inlands of the Thames, and renders very profitable, fpots which would otherwife be left wafte. It has the further value of ftrengthening the banks of ftreams, and preventing them from being wathed away 
by the force of the current. It is of very rapid growth, and when properly managed will afford an annual crop of twigs for the bafket-maker. There are feveral kinds of ozier; and fome other forts of willow are trained and cropt for fimilar purpofes, according to the fize of twigs required for different works.

There are many other fpecies of willow befides thofe above enumerated, which however in properties all approach thein more or lefs. Some dwarf kinds are met with as far north as almort any vegetables will grow, and dwindle in; bulk till they become the very lowett of trees or thrubs. 


\section{$\because(73)$}

\section{THE SCOTCH FIR, or PINE.}

\section{Pinus Sylvestris.- $P l .22$.}

Fructification. Barren flowers in bunches, each with many chives united at the tips. Fertile flowers on the fame tree in a cone, compored of fcales, with two flowers in each; the feed-bud fucceeded by a nut having a winged membrane.

Specific cbaracter. Leaves growing in pairs out of one fheath; in their firft growth folitary and fmooth.

ThE pine tribe form a large and inportant family in trees, diftinguifhed by their ftiff, narrow, pointed leaves, generally evergreen, and of a dark hue, and their fcaly cones. Some of them affeet mountainous fituations; others, bogs and fwamps; 
fwamps ; and they often compore woods of vaft extent, cloathing barren and defolate regions unfit for human culture.

The fpecies of pine now under confideration is called with us the Scotch fir, becaure it grows naturally in fome parts of the Highlands of Scotland, perpetuating itfelf by the feedlings which come up from the fallen cones. It is, however, by no means peculiar to that country, but grows abundantly in the mountainous parts of Norway, Sweden; and Ruflia, covering the fides of the higheft hills, often out of the reach of man. It will thrive in any temperate climate, and delights molt in poor fandy foils. When growing, in a thick wood or grove, it is drawn up with a ftraight naked trunk; but in an open funny expofure it fpreads out with wide branches. As the terminating buds only fend forth hoots, it will not bear the leaft clipping. Vaft plantations of this tree have been made within the lat thirty or forty years in various parts of the inland, which will at leat anfwer the purpore of improving 
improving the landfcape in naked and fterile tracts, though it is furpected that the timber will never be fo valuable as that in the natural forefts. No wood is at prefent ufed among us in a quantity approaching that of the fir; which, under the name of deal, is the principal timber employed about buildings, for flooring, planks, beams, - rafters, and the like; alfo for the upperdeck works of men of war, and for various domeftic purpofes. It has the advantage of being cheap, light, and eafily worked ; but it fplits readily, and is extremely inflummable. Deals are red, yellow, or white, according to their growth, or the different fpecies of fir whence they are procured. Almoft the whole of our confumption comes from Norway, or the countries bordering the Baltic; the firs of our own growth being fit for little more than pofts and rails. Thofe in the native forefts of Scotland, indeed, are to be excepted, but thefe afford a fmall fupply.

Befides the value of their timber, the firs 
firs of various fpecies yield the important products of turpentine, tar, and pitch. They abound in a refinous juice, which, exuding from the tree in its natural ftate, is turpentine. The fame, when forced ont by a clofe fmothered fire, is tar; and this, thickened by boiling; becomes pitch. Rofin is the refiduum of turpentine from which the effential oil has been diftilled. From all thefe ufes, the fir may be called the failor's tree with as much propriety as the oak. Indeed, the earilieft veffels built for navigation were conftructed with this material, and in the antient poets the pine is conftantly employed as a metaphorical term for a ßBip. Even at prefent, the cheapnefs of fir timber in the north of Lurope and America caufes many veffels to be built of it alone, which have the advantage of fivimming light, though they foon decay.

The white inner rind of the Scotch fir is ground to powder and mixed with rye meal in order to make bread in feafons of fcarcity, 
fcarcity, by the poor inhabitants of Sweden and Norway.

Many other fpecies of pine are now become common in our plantations. Of thefe we Thall mention a few of the principal. 


\section{$\left(7^{8}\right)$}

\section{THE SPRUCE FIR,}

\section{Pinus Abies.-Pi. 23.}

Fruclification. As the former. Specific characler. Leaves folitary, awlfhaped, pointed, fmooth, turned two ways.

$-T_{\mathrm{HIS}}$ is a fine and large tree, growing plentifully in the mountain-woods of Norway, and valuable for its timber, which is faid to afford the white deal. From the green tops of this fpecies is made the fprucebeer, fo much efteemed in America as a remedy for fcorbutic diforders. 


\section{.$(79)$}

\section{THE SILVER FIR.}

\section{Pinus Picea.-Pl. 24.}

Fruclification. As the former.

Specific cbaracter. Solitary notched leaves: cones pointing upwards.

Thrs fpecies grows to a ftraight tall tree, and is one of the moft fightly of the kind. It receives its name from the hue of its leaves, which are of a full green in their upper furface, but, in the under, have two white lines running parallel to the midrib on each fide, which give it a filvery appearance as viewed from below. The leaves in their form and manner of growth refemble thofe of the yew, whence it has been named the yew-leaved fir. The Latin appellation, picea, is borrowed from 
its being that whence tar or pitch is chiefly extracted. It is a native of Norway, and is faid to yield the yellow deal. The cones grow to a great fize, and foon fhed their feeds. 


\section{$\therefore H(8 I)$}

\section{THE WEYMOUTH PINE.}

\section{Pinus Strobus.-Pl. 25.}

Fructification. As the former.

Specific character. Leaves, five growing out of each theath.

THIs fpecies, a native of North America, where it is called the white pine, grows to the greateft height of any of the tribe, often arriving to that of one hundred feet. It is therefore preferred to the reft for nafts of Thips; and our largeft men of war are furnifhed with them from trunks of this pine collected in the yards of Nova Scotia. They were firft cultivated in England by Lord Weymouth, whence they are generally known here by his name; 
name; and they are now common in our plantations.

This tree has a fmooth delicate bark, and its branches are well cloathed with leaves. Its long cones hang loofely down, and foon thed their feeds. 
$(83)$

\section{THE LARCH.}

Pinus Larix.-Pl. 26 .

Fructification. As the former. Specific cbaracter. Leaves long, narrow; in bundles fpreading like a brufh, deciduous.

This tree, a native of the Alps and Apennines, has become a favourite with us, and is now extremely common in our nurferies and plantations. In beauty of appearance; and durability of wood, it much furpaffes the Scotch fir, and will thrive in foils and fituations equally unpromifing. Its leaves fall in the winter, but not till they are almoft ready to be immediately fucceeded by frefh ones. Some larches make a beautiful thow in flowering-time with the bright purple tips of their female buds.

c 2

Their 
Their branches have a tendency to hang downwards; and the trees, when they have room to fpread, feather quite to the ground, forming an elegant cone of verdure. The wood is confidered as almoft unperifhable in the countries where it is employed for timber. The larch is very refinous, and yields the turpentine commonly called Venice. 


\section{$(85)$}

\section{THE YEW.}

\section{Taxus Baccata.-Pl. 27.}

Fructification. Barren flowers, without petals, confifting of many united chives. Fertile flowers, generally on a feparate tree, without petals, fucceeded by a berry, fucculent, globular, open at the end, containing one feed.

Specific character. Long, narrow, pointed leaves, growing near together. Bark reddifh. Berries red.

$T_{H E}$ yew is a native tree of this country, and is found in rocky and mountainous fituations, where, though of now growth, and moderate height, it fometimes arrives at great thicknefs of trunk. It is, however, more commonly feen in a planted . ftaie, particularly in church-yards, proG 3 bably 
bably on account of its being an evergreen, and furnifhing boughs for the decoration of churches at the feafon of Chritmas. This fituation, and the gloomy darknefs of its foliage, have caufed it to be named " the funereal yew." It is, however, more celebrated for the antient ufe of its wood in making the moft formidable weapon of our anceftors, the long bow. Its toughnefs and elafticity rendered it peculiarly fit for this purpofe: Thus Spenfer characterifes it as

'The eugh obedient to the bender's will.

\section{busnicy exerts?}

Much force was, however, required in. overcoming its refiftance, and the archer muft have had a ftrong arm

And almoft joined, the horns of the tough yew,

It was commonly planted near houfes, both on account of its utility, and its fitnefs for being cut into thofe artificial Thapes which were formerly thought highly curious and ornamental. Pyramids, obelifks, 
lifks, birds and beafts of yew decorated the court-yards of our country-houfes, and fupplied matter of admiration to the gaz. ing paffenger. A better ufe of its obedience to the thears was made in the tall and impenetrable yew hedges, which theltered and protected the antient gardens. The yew, however, has always lain under the inputation of poffeffing noxious qualities. It is thought prejudicial to bees, and horfes and cows have been killed by cating quantities, of its clippings. There are even inftances of a fmall dofe of the frefh leaves proving fatal to children to whom it was given as a remedy for the worms. The fiveet and vifcid berries are eaten without inconvenience. The wood is at prefent valued by cabinet-makers and inlayers on account of its beautiful red veins; and is alfo a good material for axles, cogs for mill-wheels, flood-gates for fithponds, and other works of ftrength and durability. 


\section{THE HOLLY.}

ILEX AQUifolium.-Pl. 28.

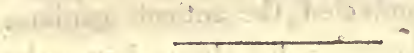

Fructification. Flowers generally with four chive's and four pointals on each, (but fometimes the barren and fertile feparate,) fucceeded by a berry with four cells and one feed in each.

Speciffic cbaralter. Leaves oval, pointed, thorny.

Tab holly grows native in woods to the height of twenty or thirty feet; but we more ufually fee it in gardens in the ftate of a hrub. It is an evergreen, and by its fhining leaves and red berries forms a principal decoration in the winter landfcape. Armed by, nature in its own defence with thorns projecting from the indentations of the leaves, it has been fe-

lected 
lected by man for the protection of his cultivated plants, and formed into hedges impenetrable to all the foes of the garden. Were it not for its now growth, no native of this climate would be preferred to the holly for this purpofe. Mr. Evelyn fpeaks with rapture upon this fubject. "Is there," fays he, "under heaven a more glorious and refrefhing object of the kind, than an impregnable hedge of about four hundred feet in length, nine feet high, and five in diameter, which I can fhow in my now ruined gardens at Say's Court, at any time of the year, glittering with its armed and varnithed leaves; the taller ftandards at orderly diffances, blußhing with their natural coral ? It mocks the rudeft affaults of the wcather, beafts, or hedgebreakers, Et illum nemo impune lace/3zt."

By the fkill of the gardener numerous varieties are derived from the common or wild holly, diffinguifhed by the variegations of their leaves, and difpofition of their prickles. Some of thefe are very curious and beautiful, and afford rich ornaments to

a Ahrub- 
a Thrubbery. The wood of the full-grown holly is valuable. It is the whiteft of all our hard woods, and therefore ufed by inlayers, and is fometimes ftained black to imitate ebony. It is alfo excellent for the ufes of the turner, carver, and mill-wright, being extremely firm and durable. Birdlime is made of the green bark of the holly, firt boiled, and then laid in a damp place to ferment, by which it is converted to a perfect mucilage or flime. 


\section{( $\left.9^{1}\right)$}

\section{THE BOX.}

\section{Buxus Sempervirens.}

Fructification. Barren flowers with two petals and four chives. Fertile flowers in the fame bud, with three petals and three thafts, fucceeded by a roundilh capfule with three bills and three cells, having two feeds.

Specific charailer. Leaves oval, thick, gloffy. Bloffoms greenifh white.

$\mathrm{T}_{\mathrm{HE}}$ box is another evergreen tree or fhrub, which is met with, though fparingly, in a wild ftate with us, but more commonly as planted in our gardens. Its rarenefs (probably owing to a foreign origin) may be inferred by its having given a name to thofe fpots where it is principally found; as Box-hill, in Sur- 
rey; Boxley, in Kent; and Boxwell in the Cotfivould in Gloucefterfhire. In all there places the box grows in woods or thickets; it is alfo plentiful upon the chalk hills near Dunftable. A ftony fhallow foil, of the lime-ftone kind, feems bet to fuit it. In old gardens it was much cultivated for the purpore of clipping into thofe artificial forms which were once to much adinired; and alfo for hedges. A dwarf kind is ftill one of the commoneft borderings of floser beds, and pleafes the eye by its perpetual verdure. The wood of the box is of a pale yellow colour; and being vèry hard, fmooth, and folid, is much valued for various purpores. The principal of there are the making of combs, mathematical rulers and other inftruments, flutes, thuttles, and turnery wares. It bears a high price, and may be cut about every thirty years.

FINIS. 
$\dot{ }$
$=$ 


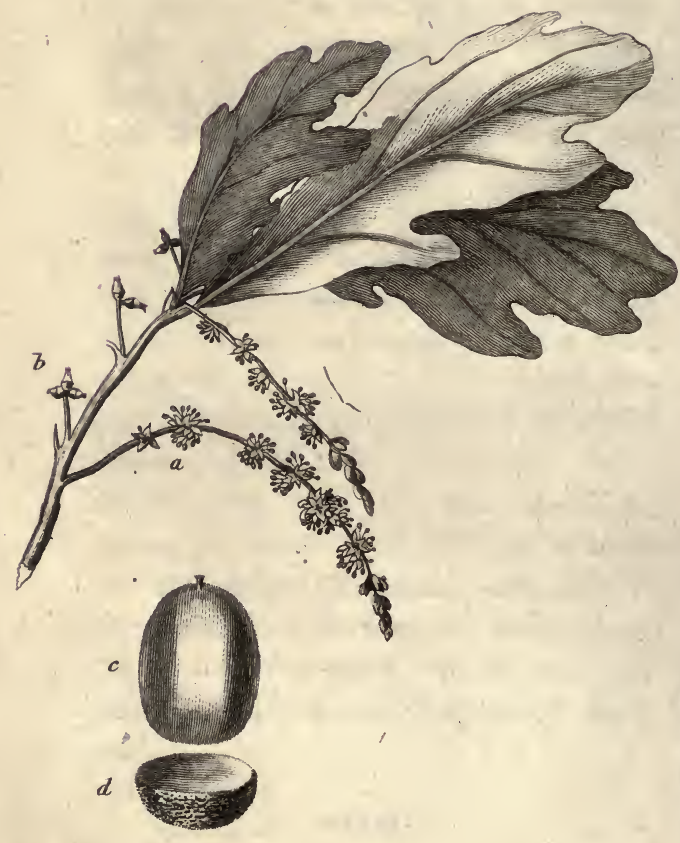
a. Male catkin.
b. Female flowers.
c The Nul.
d. The Cup.

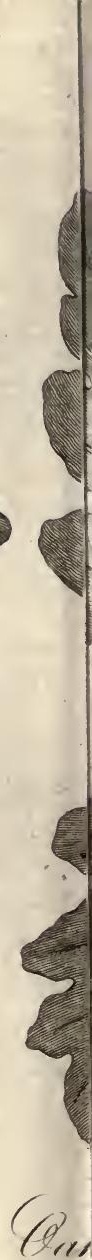


PI.I.

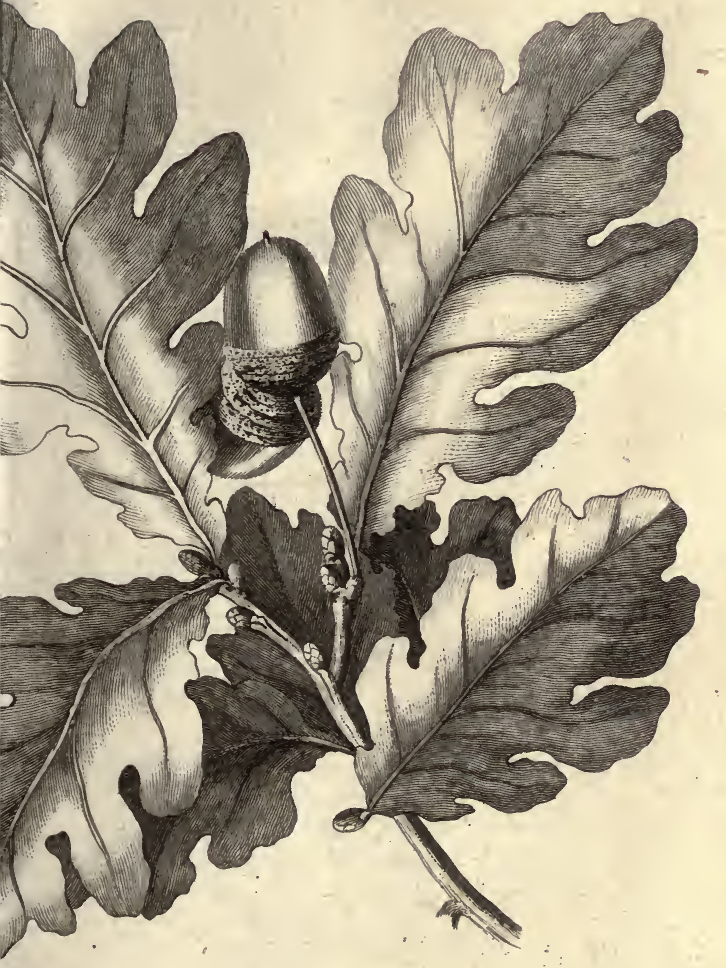




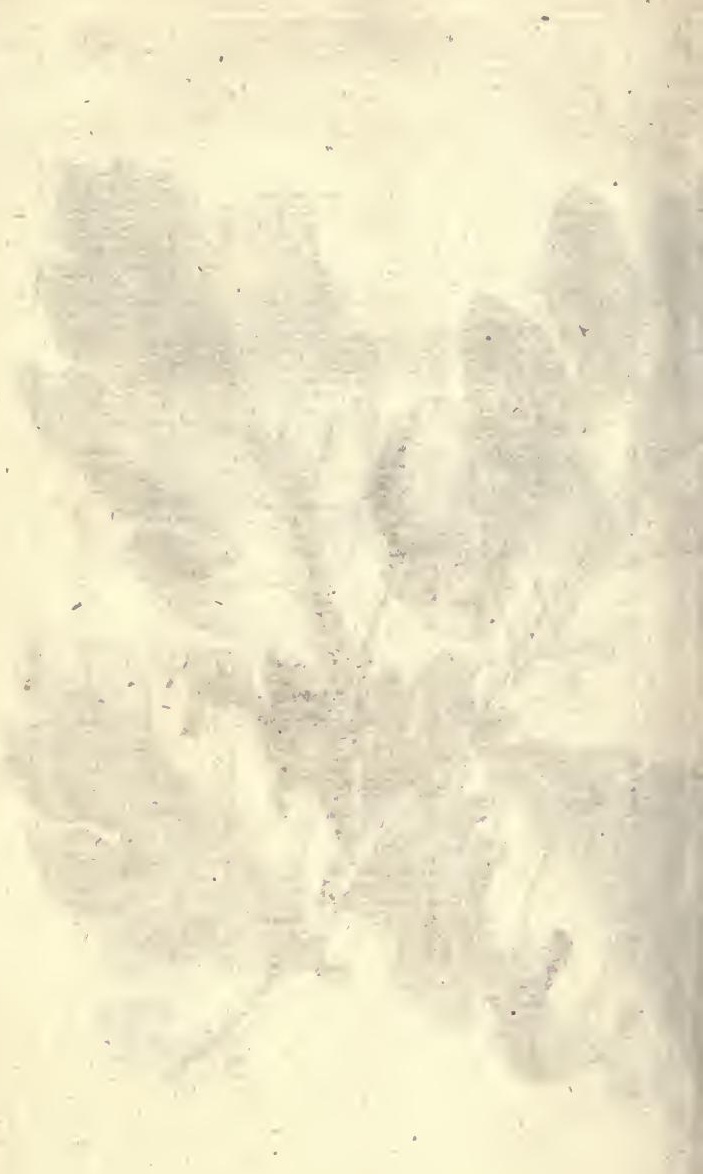


:

$+x+1+\infty$

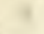

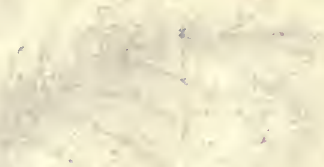

$x=$

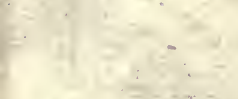

$\frac{i}{i}-\frac{i}{x}=$

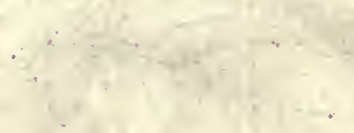

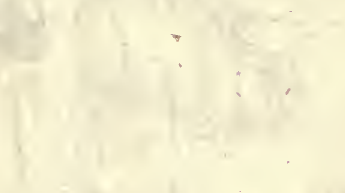




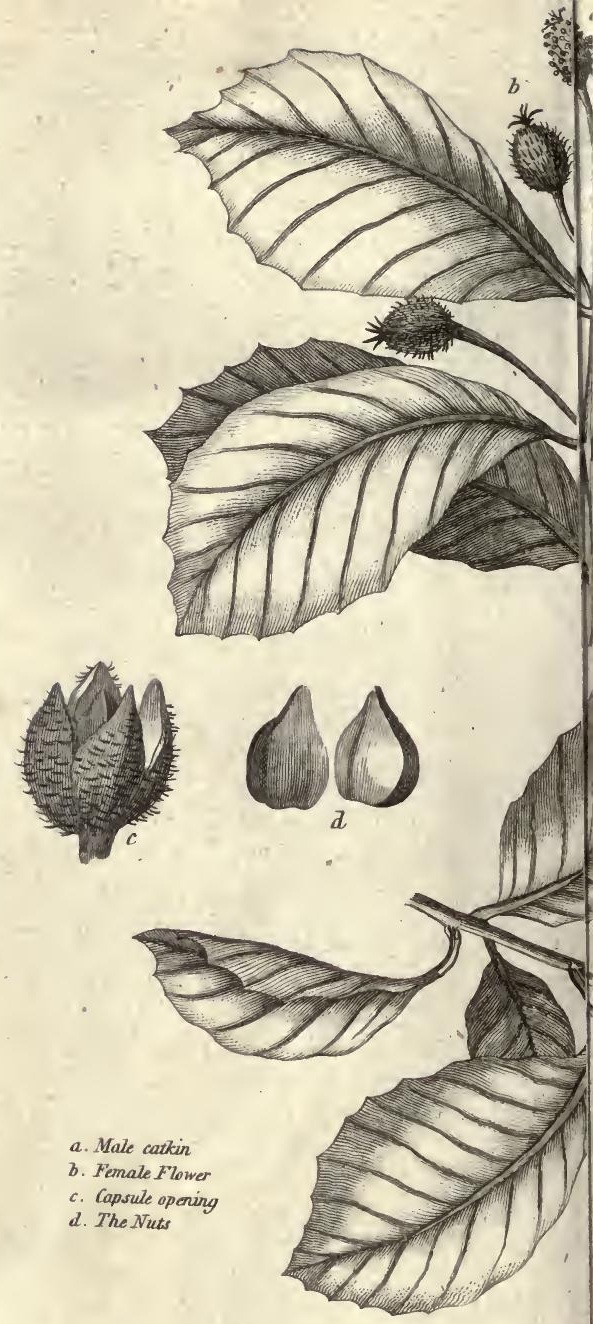




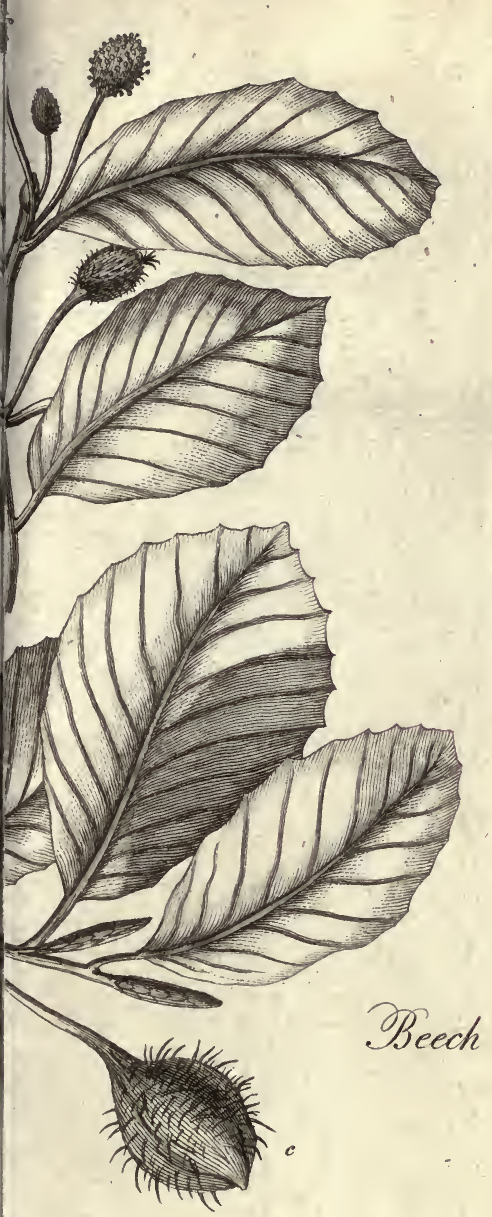





\section{4}

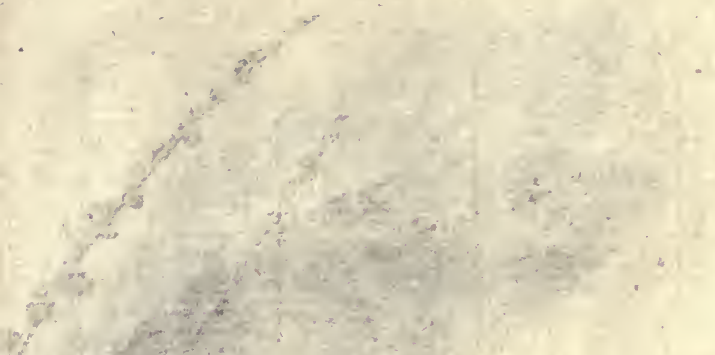

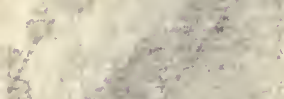

$2+\frac{1}{2}$

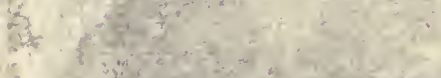

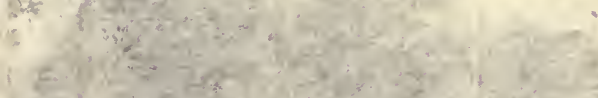

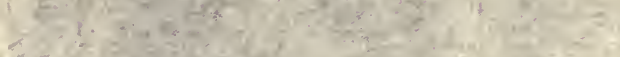

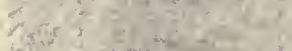

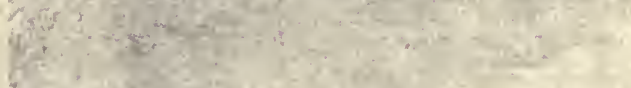

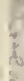

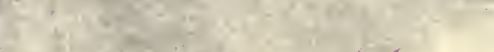
s. 2

1

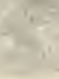

tivas

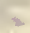
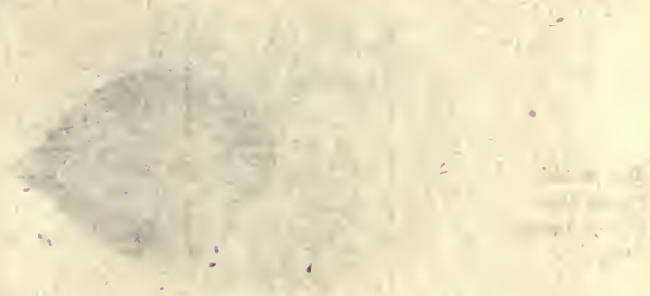


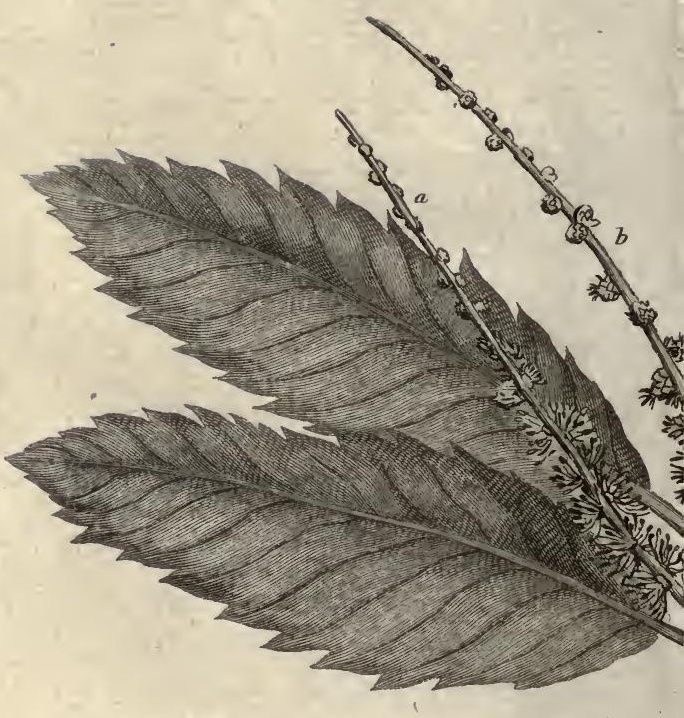

a. Male atkin.

b. Female Buds

c. Capoule opening.

d. Nut .
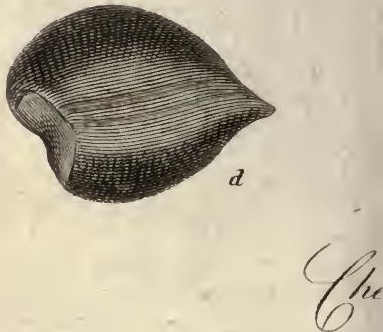



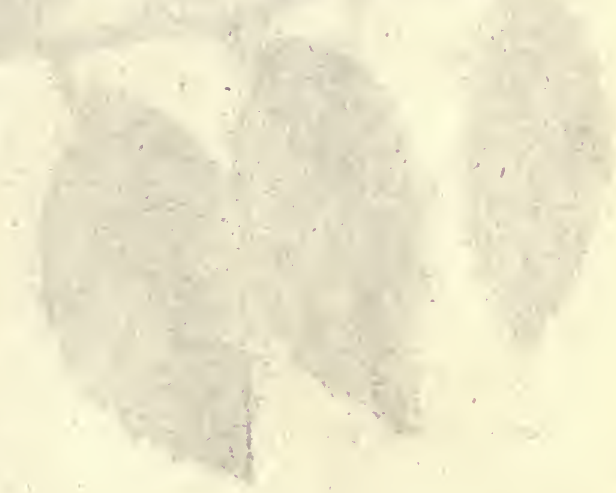




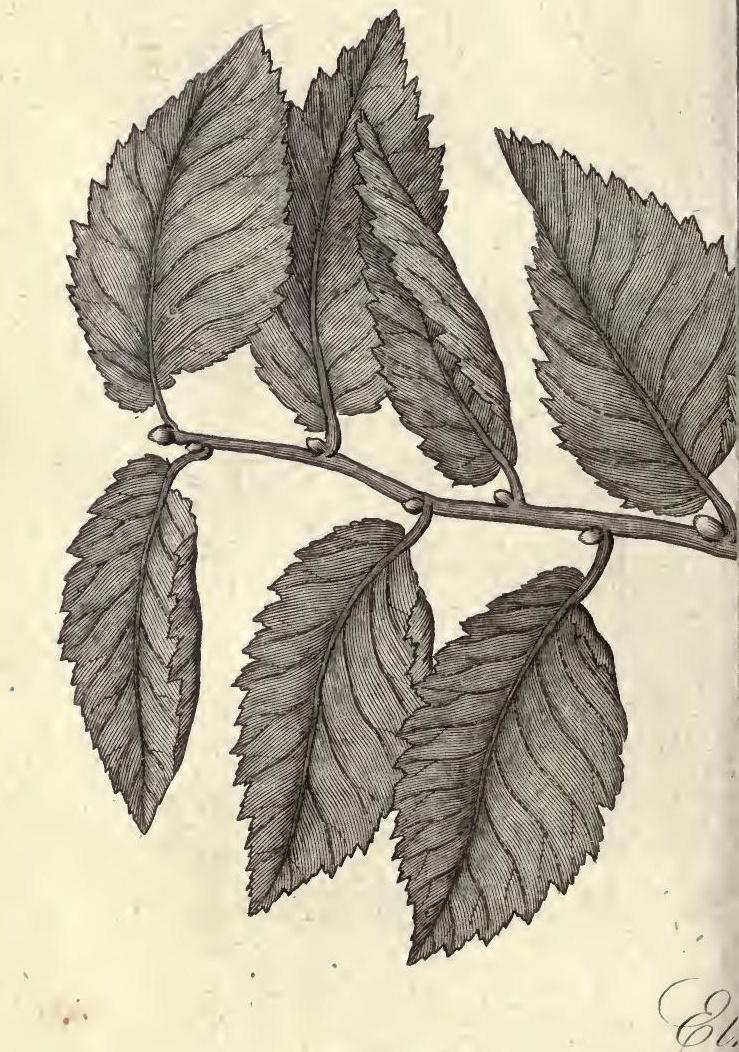




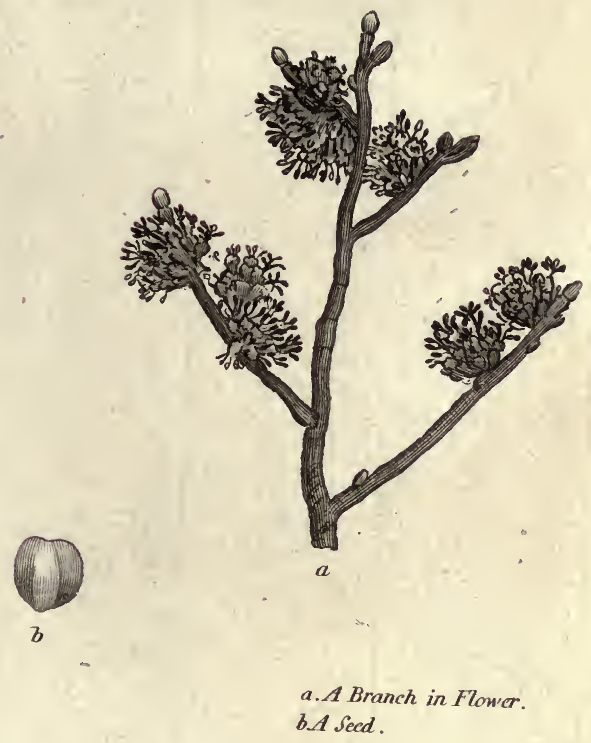




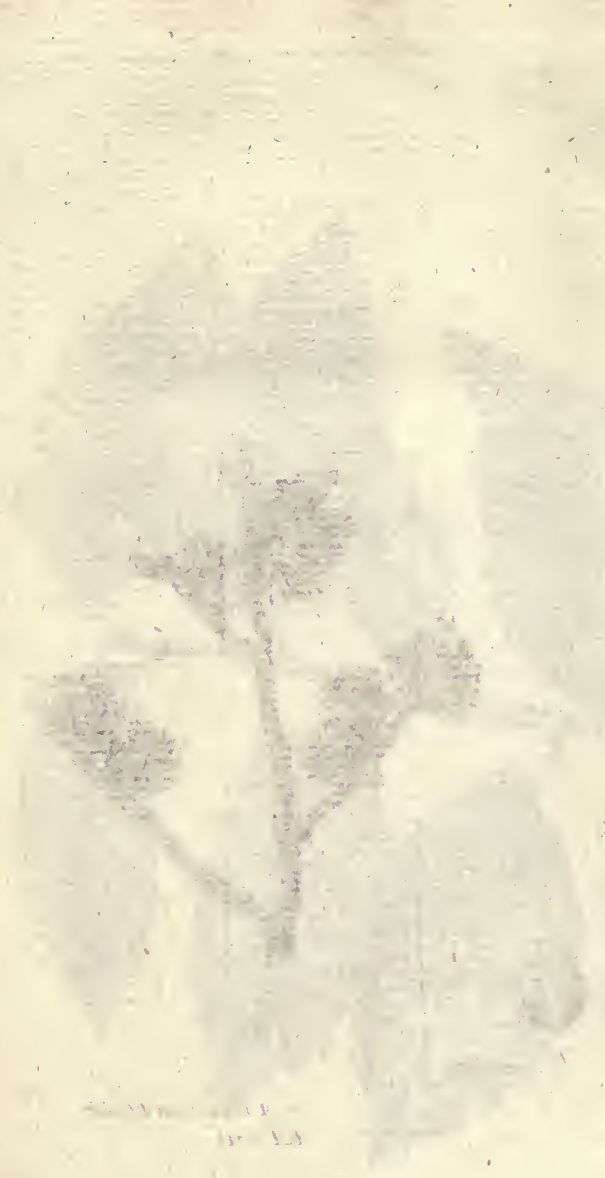




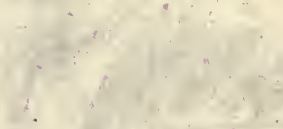

$=x_{x}-t$
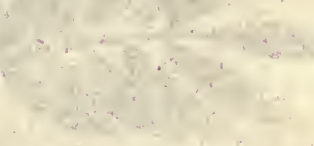


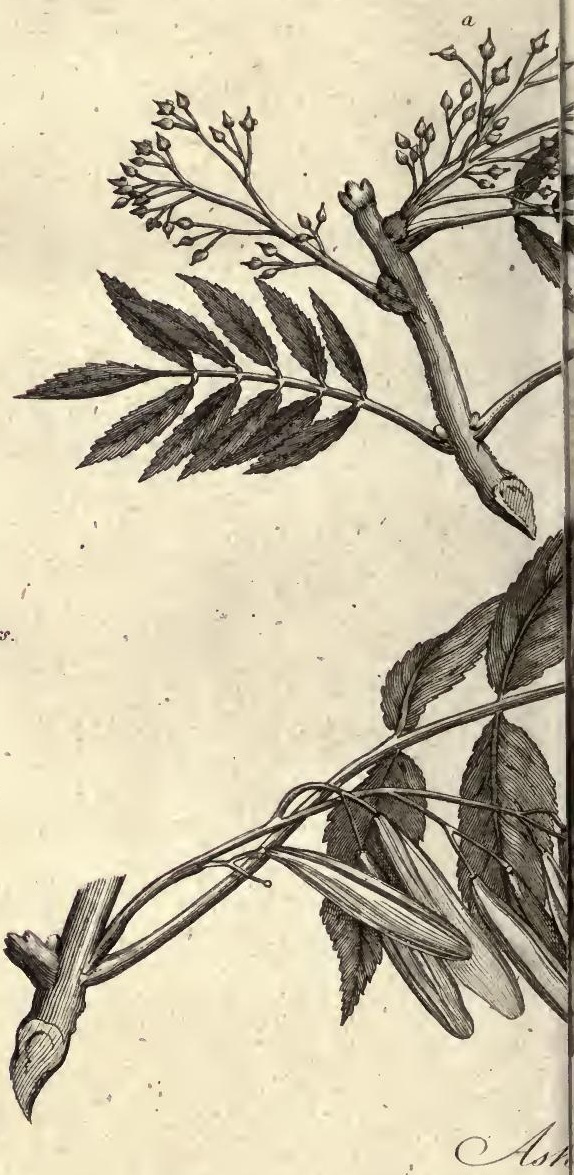

a. Bunch of flowers.

b. A winaed seed .

c. Sced naked. 

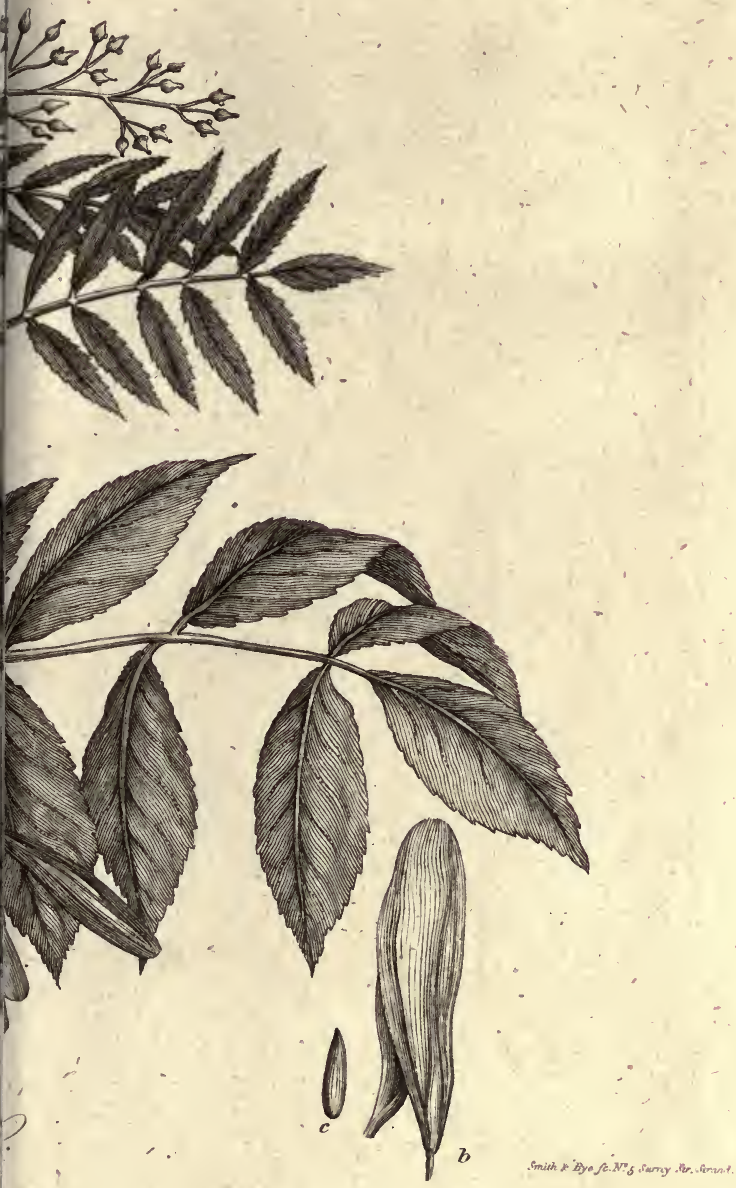


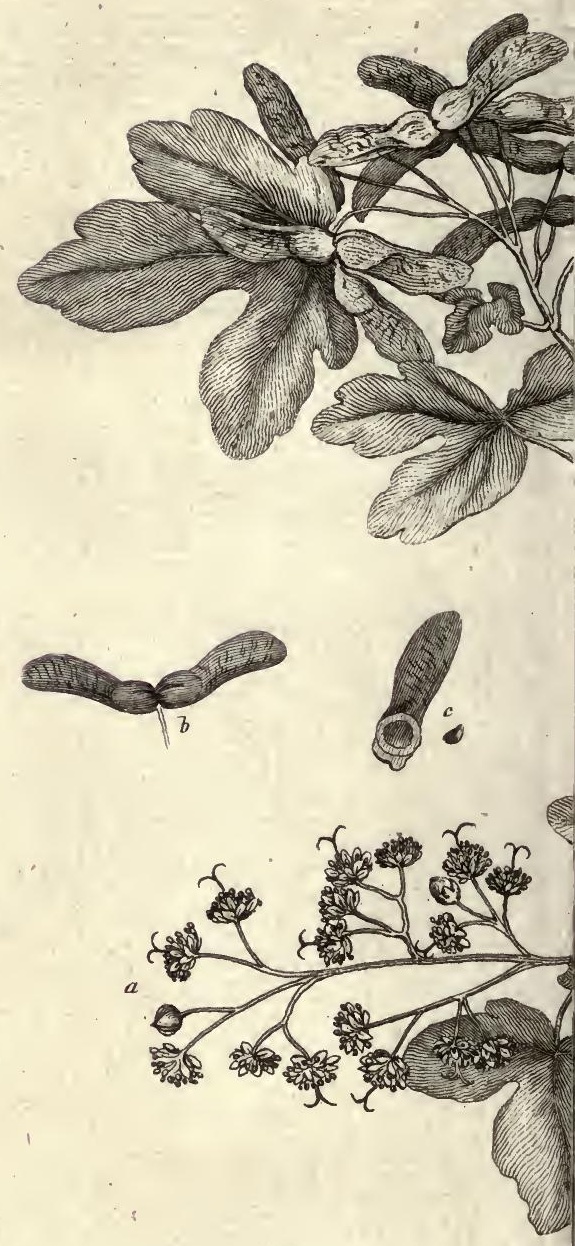


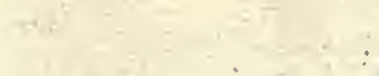

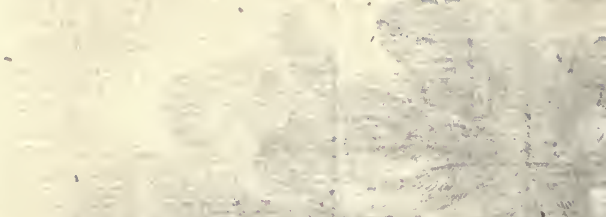

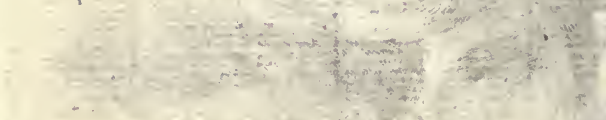
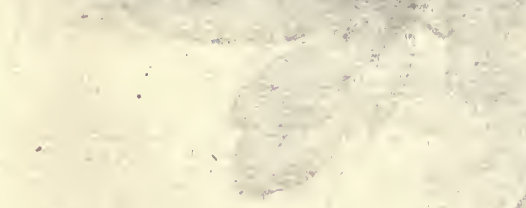

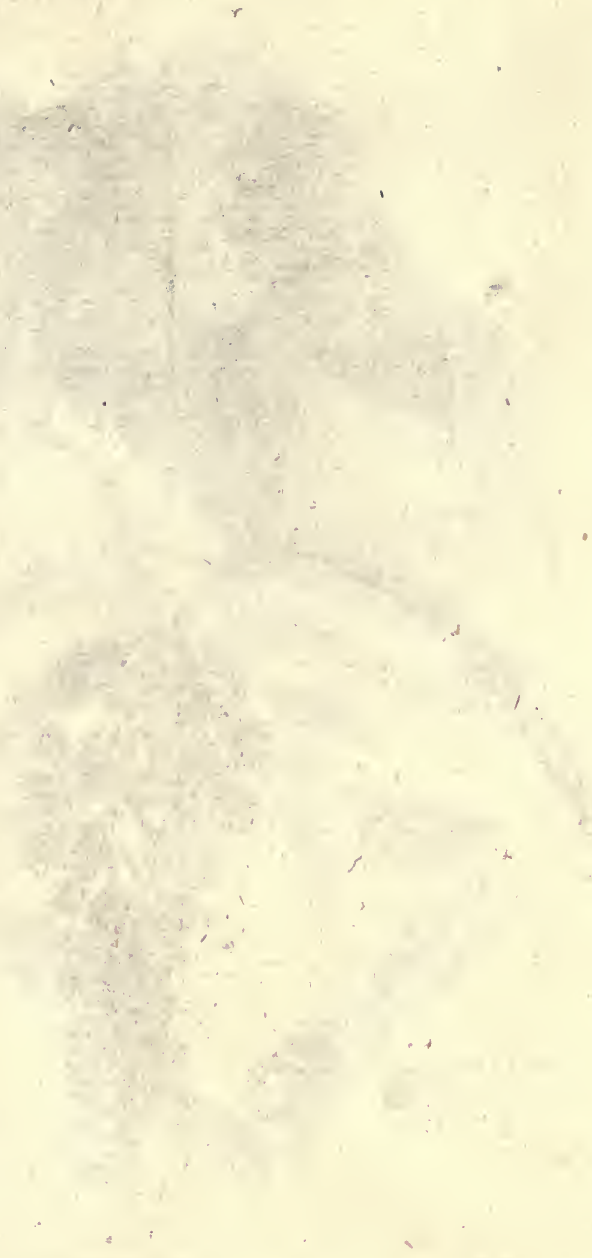


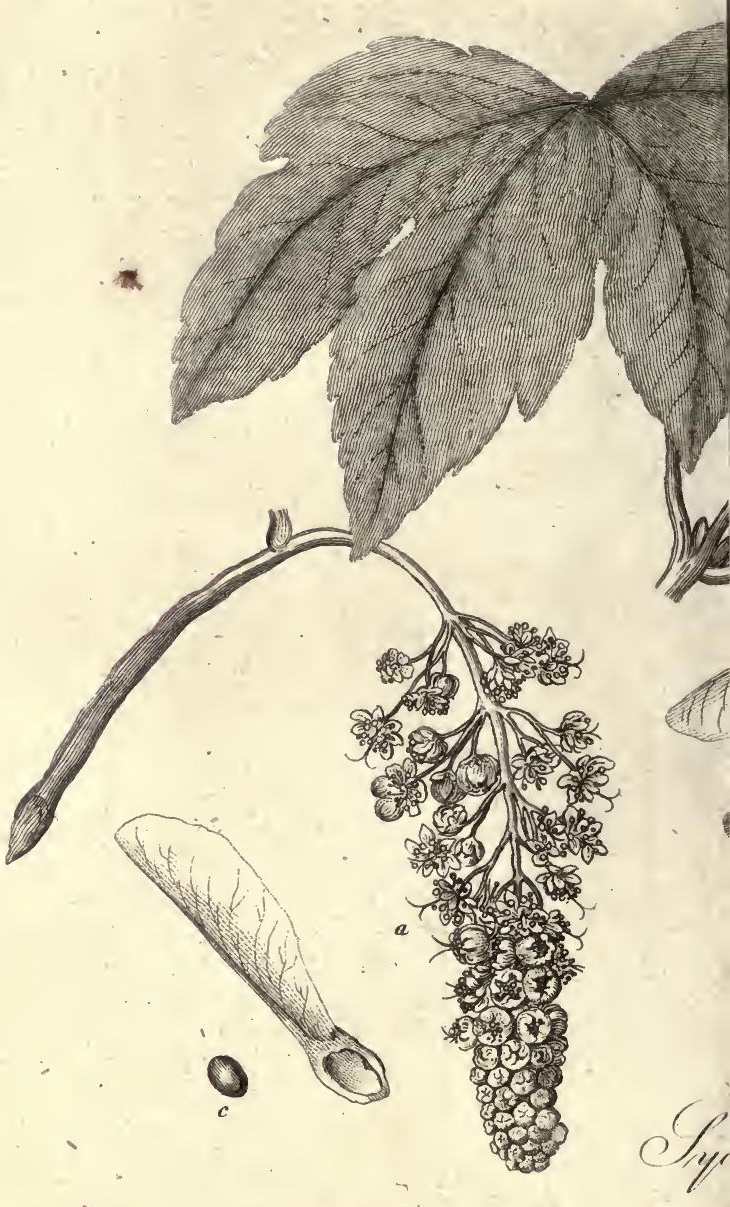



III
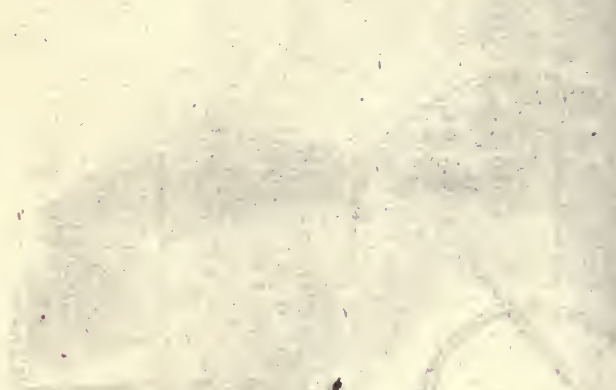


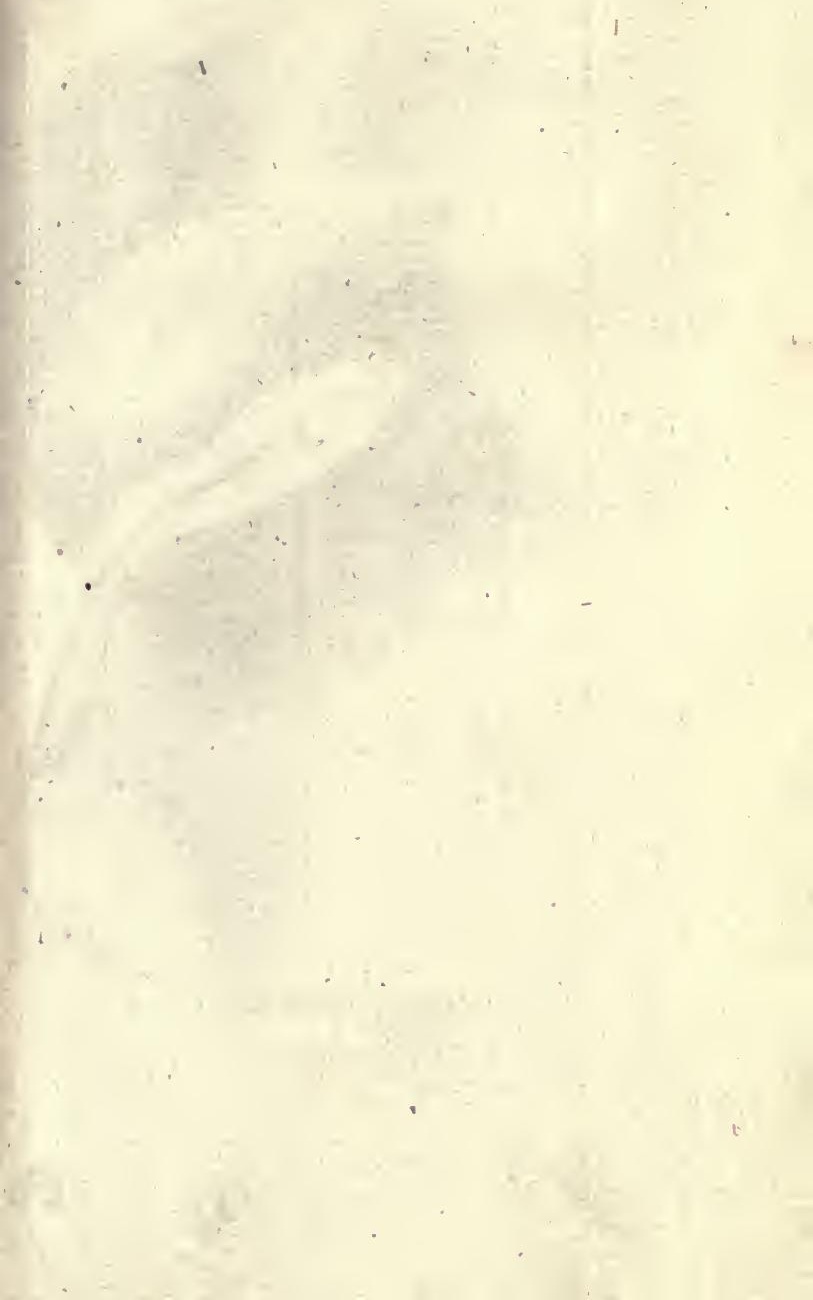




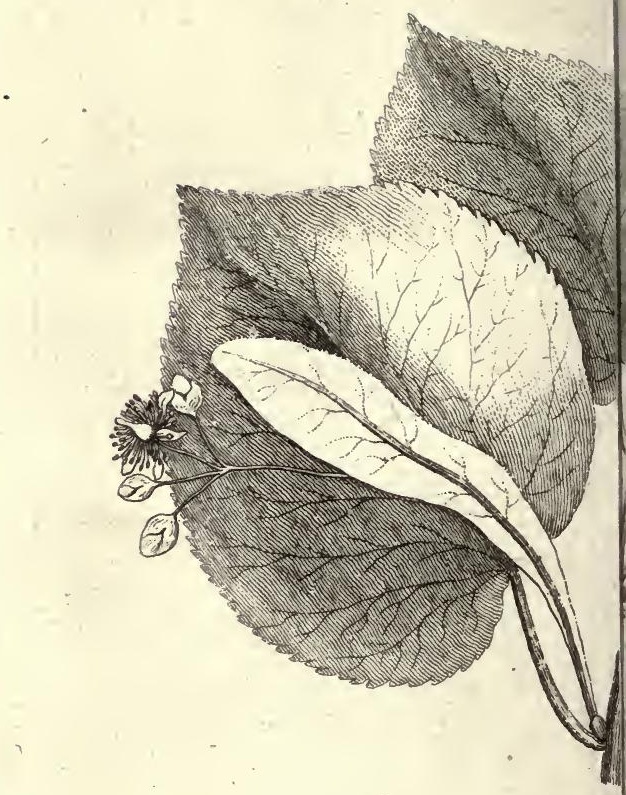

a. Flowers with floral leaf

b. Capsule. $\rightarrow$

c. Do. aut transwersly.

d. Sead. 

1

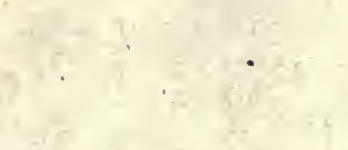

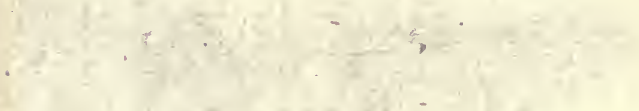

I. $1+x=$

2

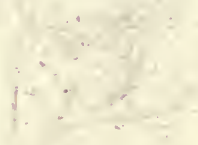




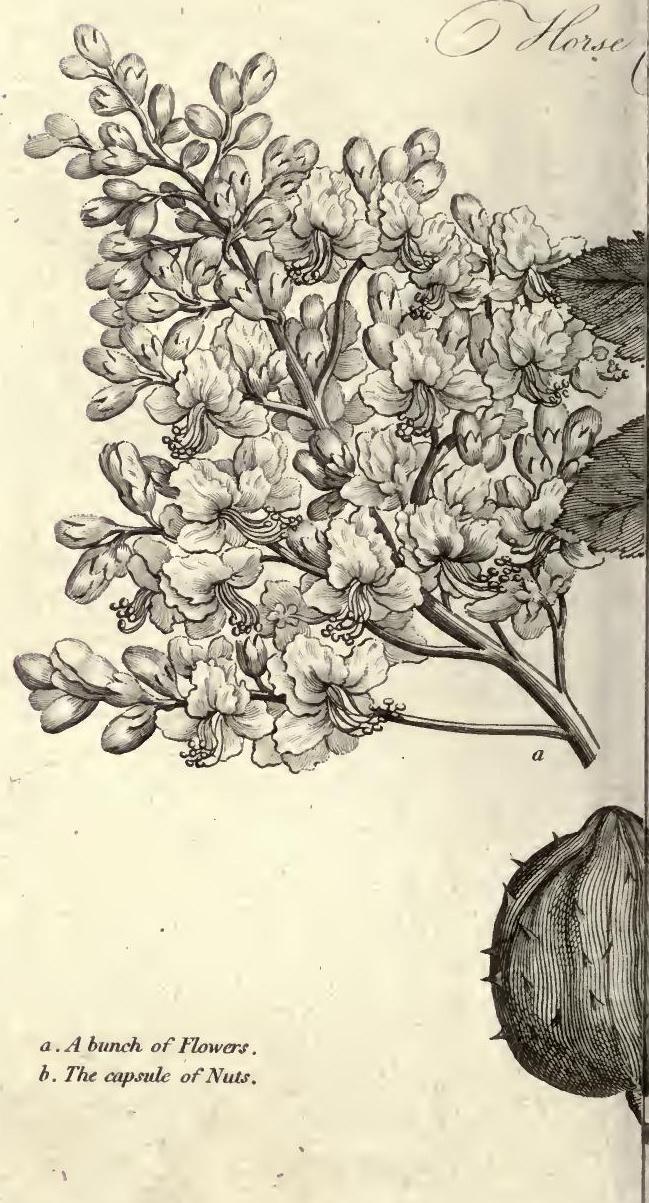






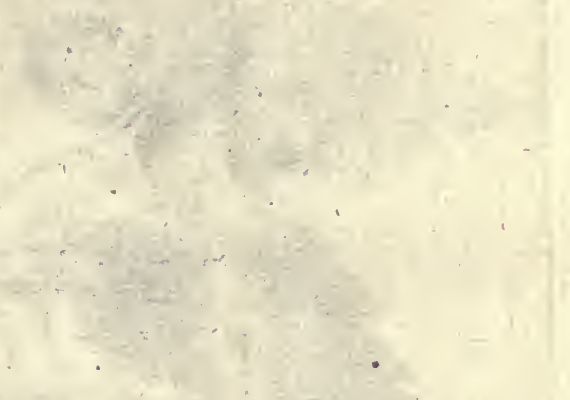

,

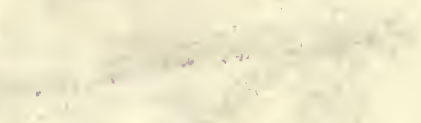

. 


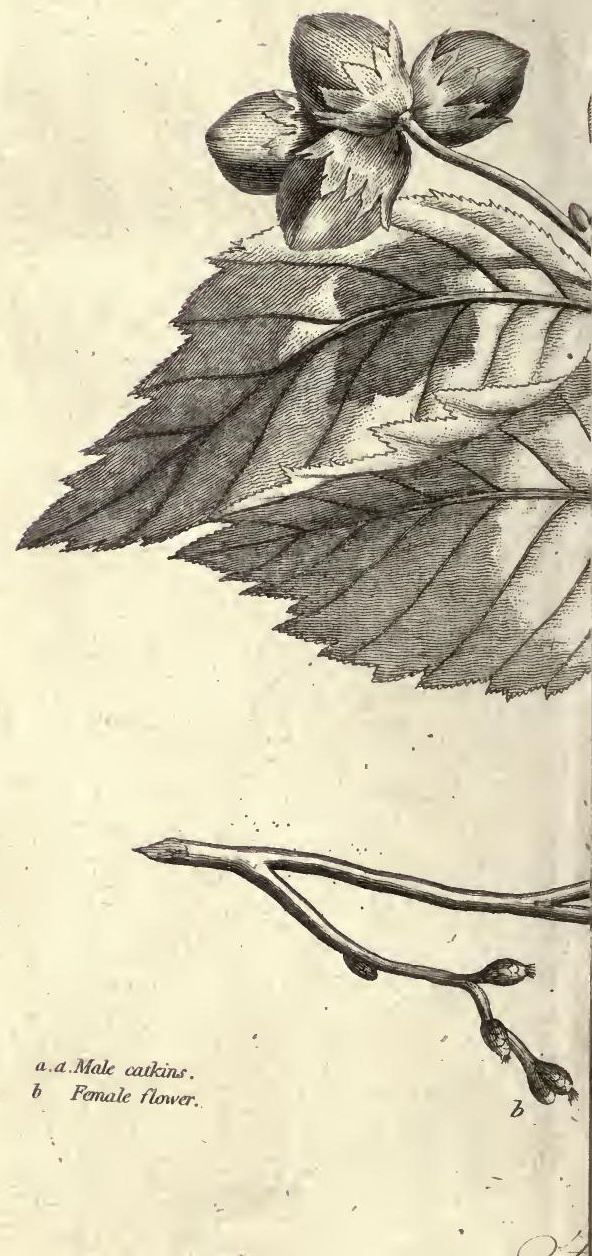




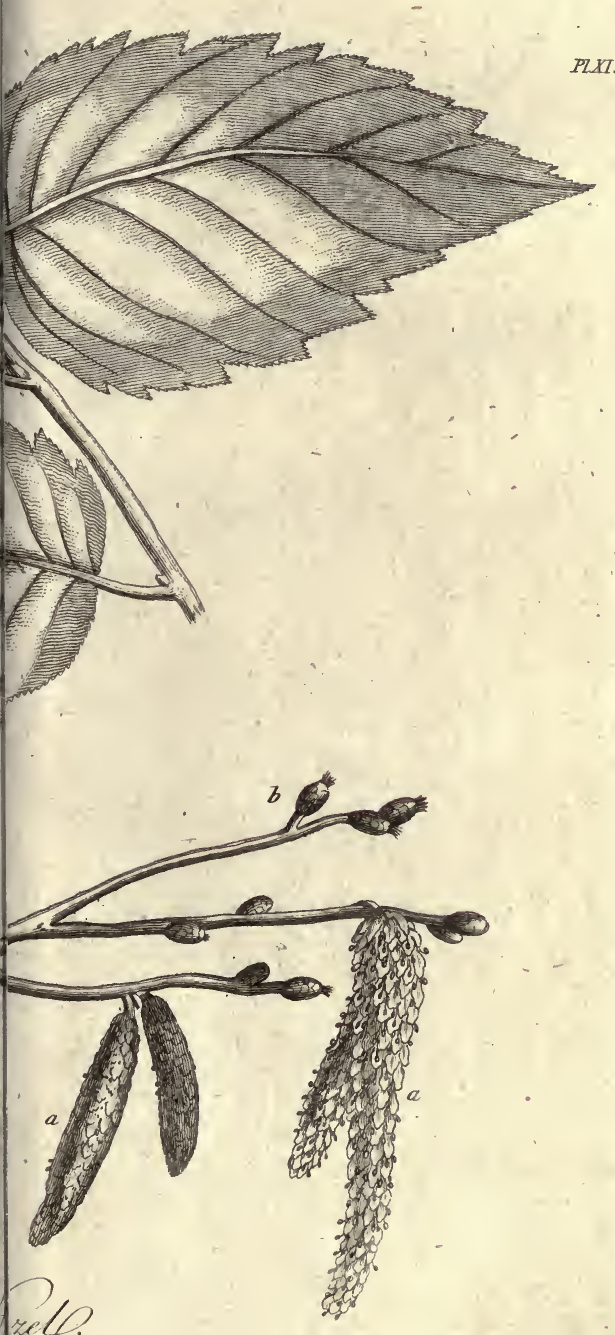





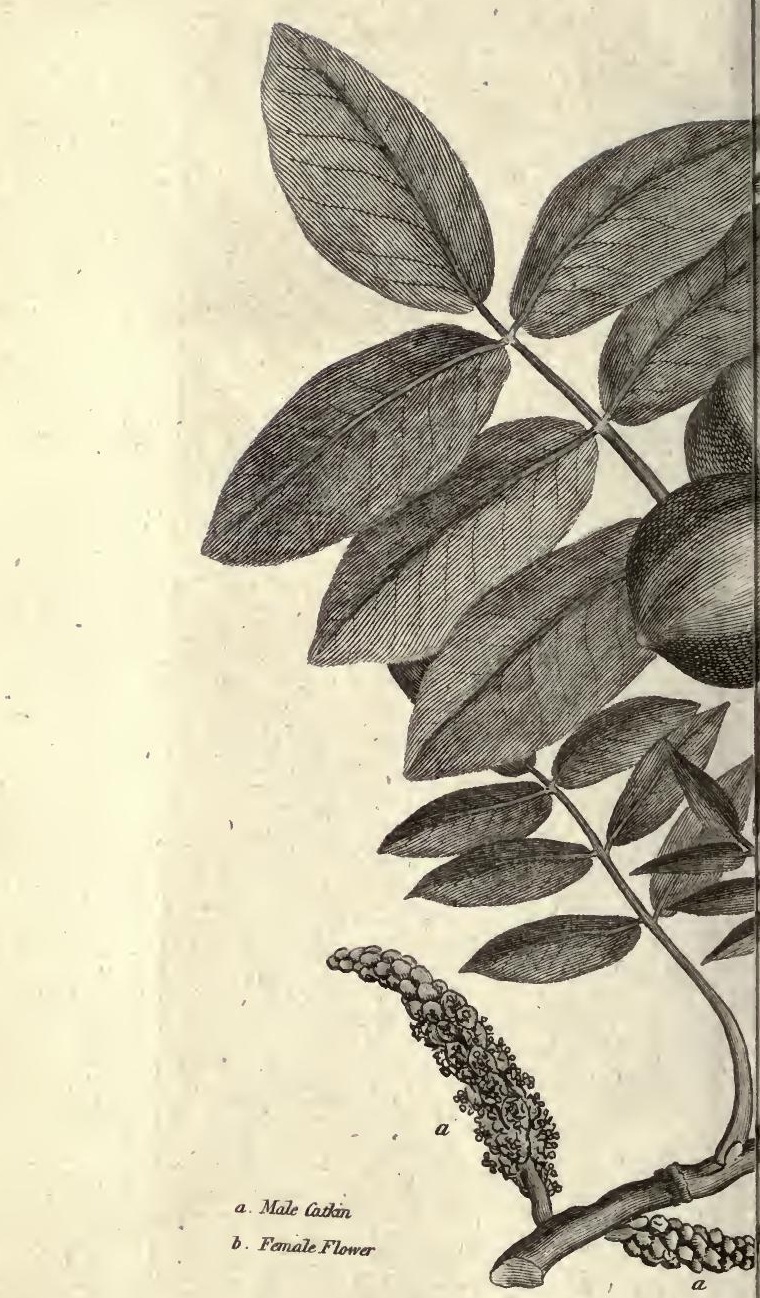




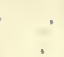

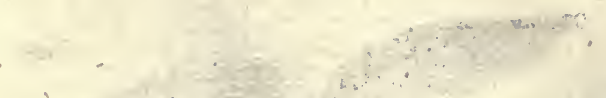

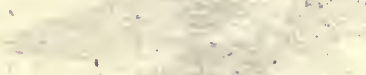
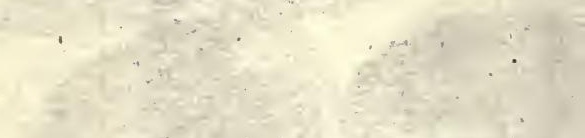

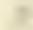
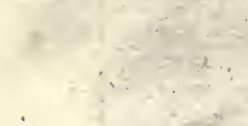


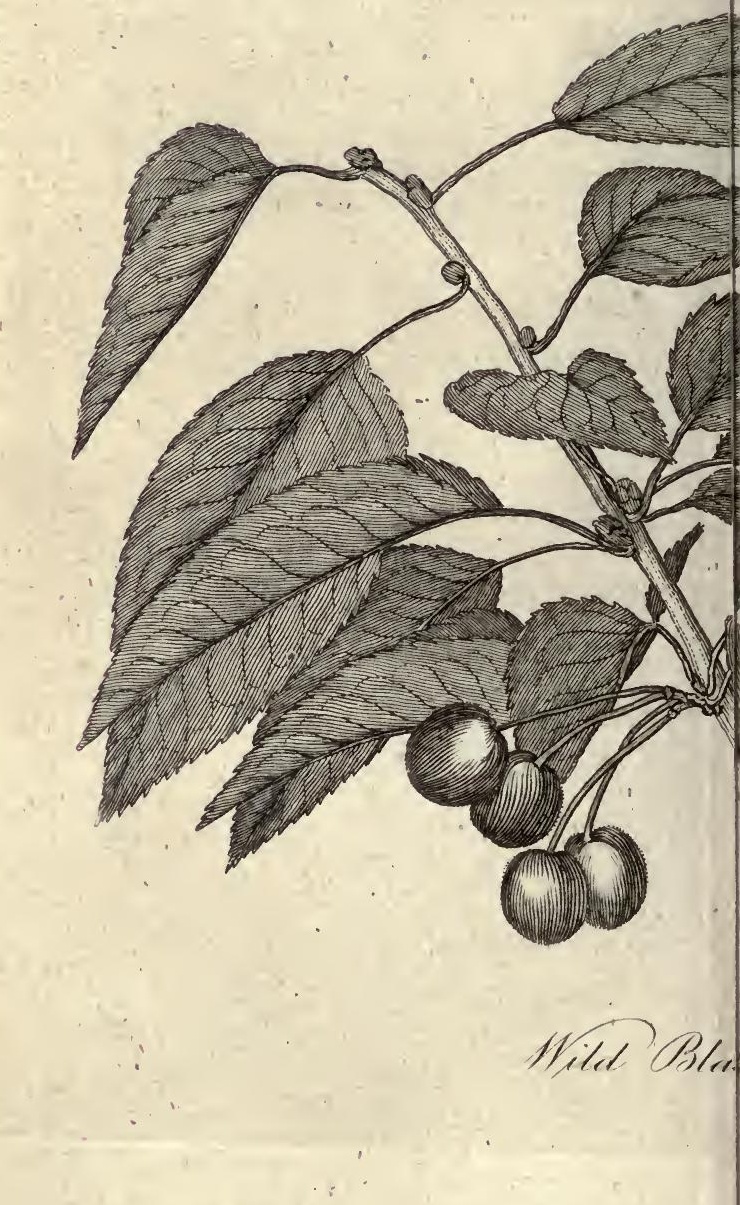



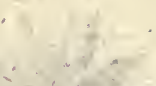

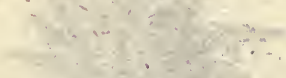

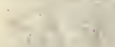
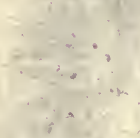

$\therefore$
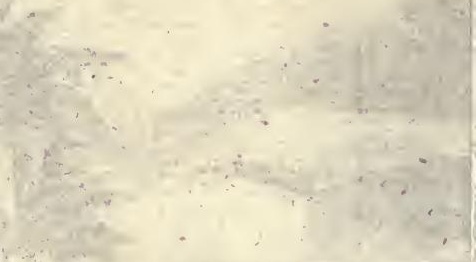

, \%
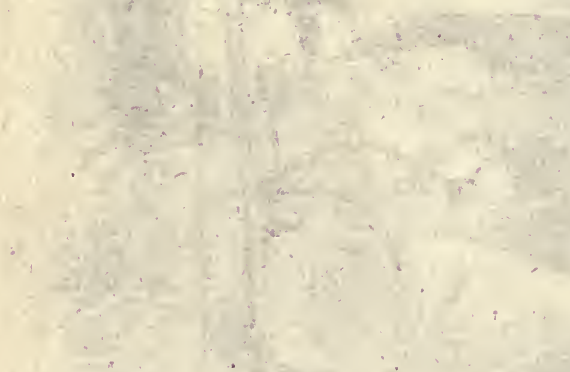


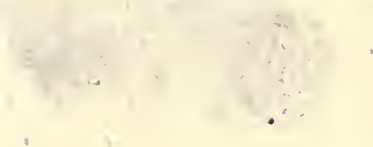




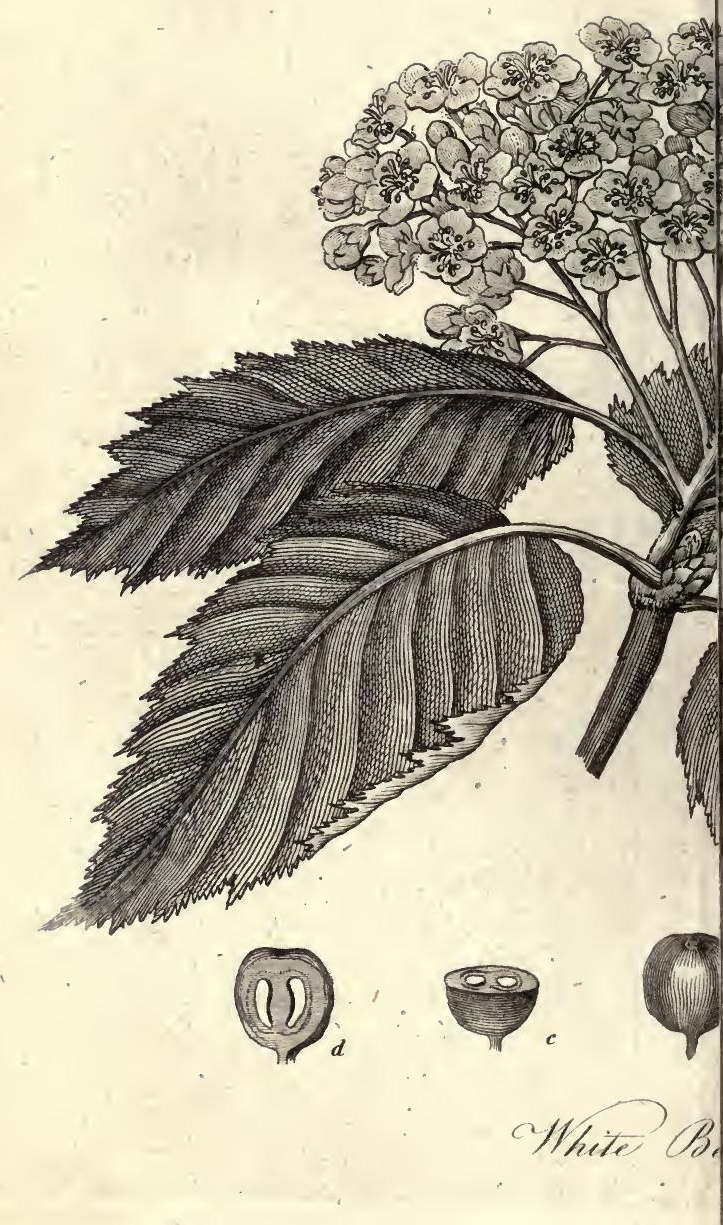



$-1$

i

$4=\therefore-a^{\prime}=$
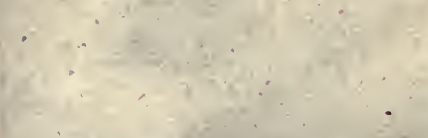

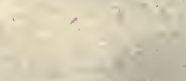

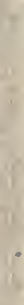

18

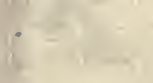

$\checkmark$
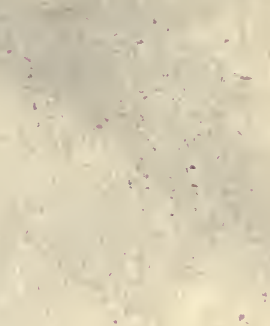


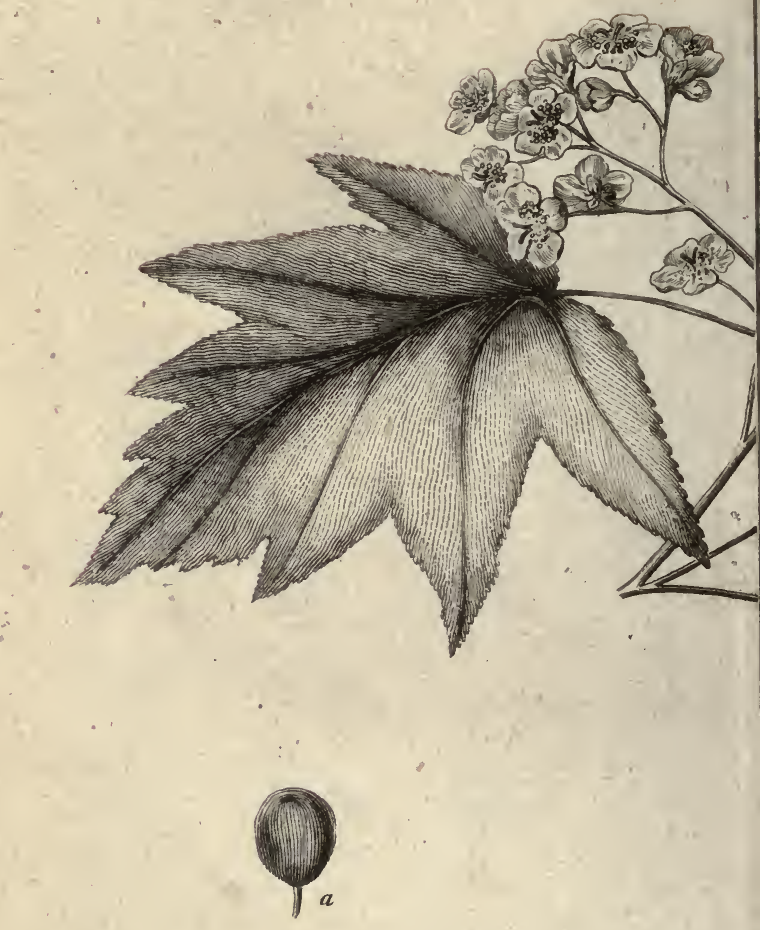

a A.Bary

$$
\text { Hild ofmene? }
$$



(1)

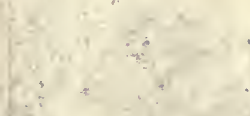

$+2 \div 2=$

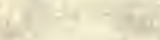

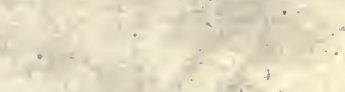

, i. .

?

(x+2)

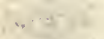
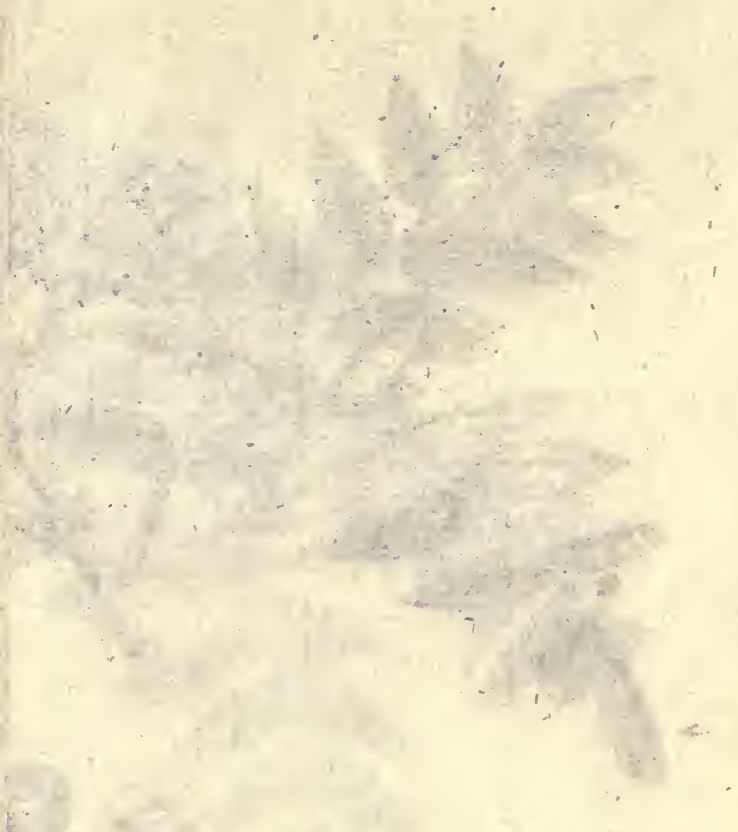

.

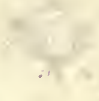




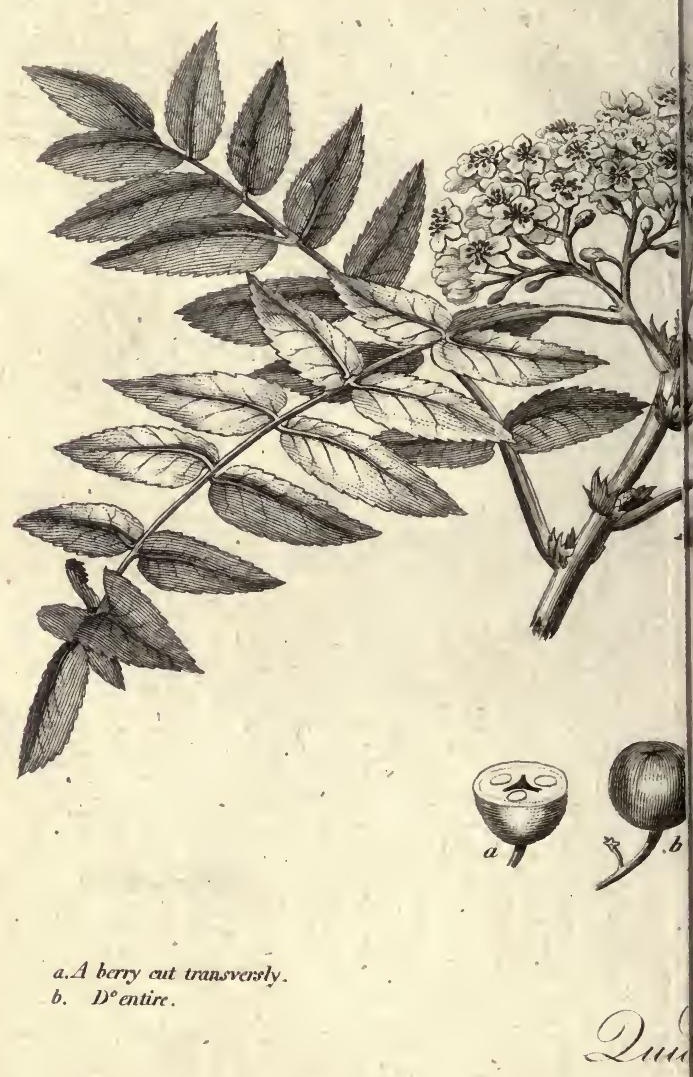



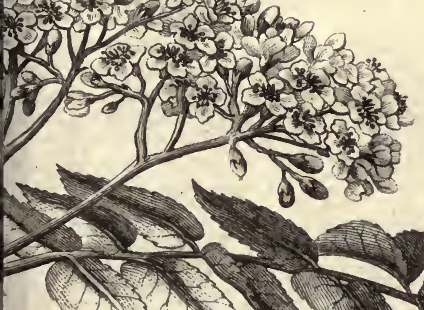

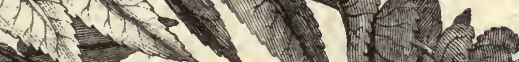

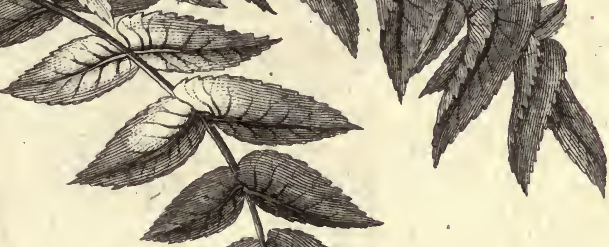

,

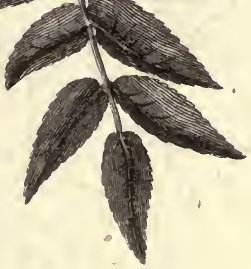




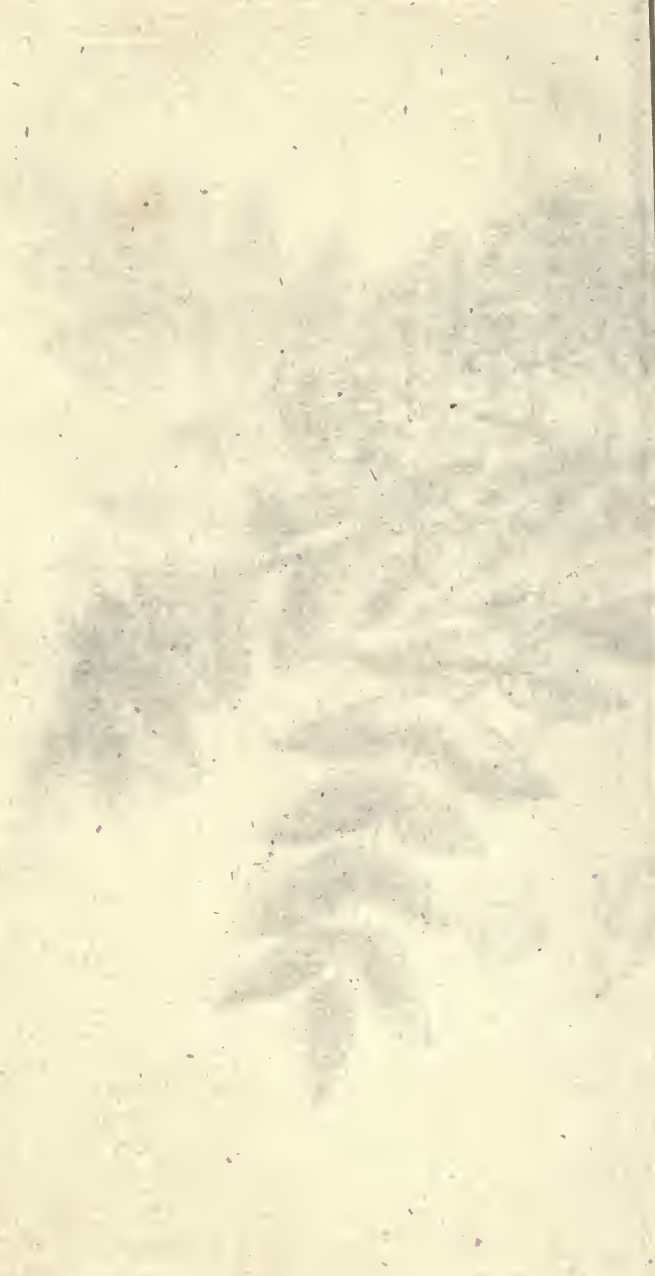




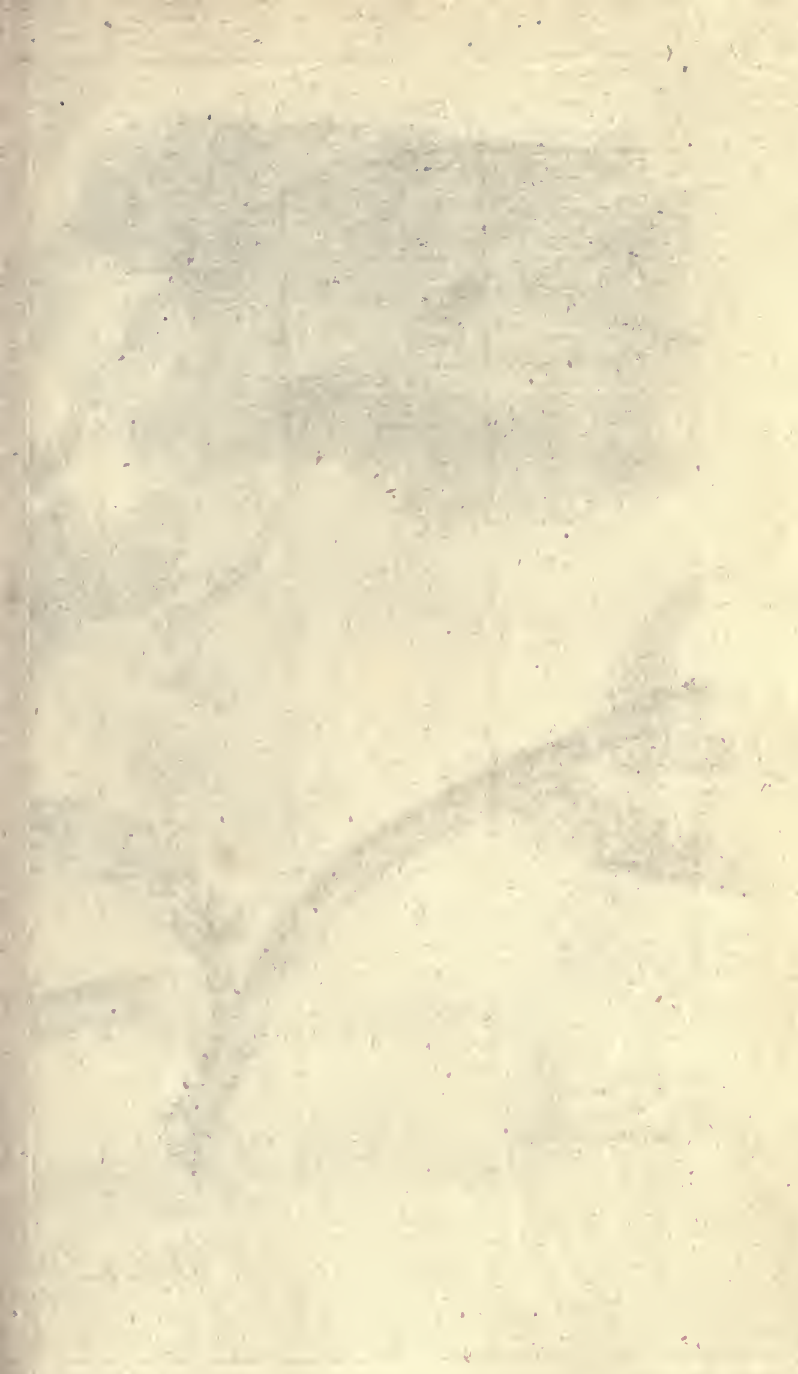




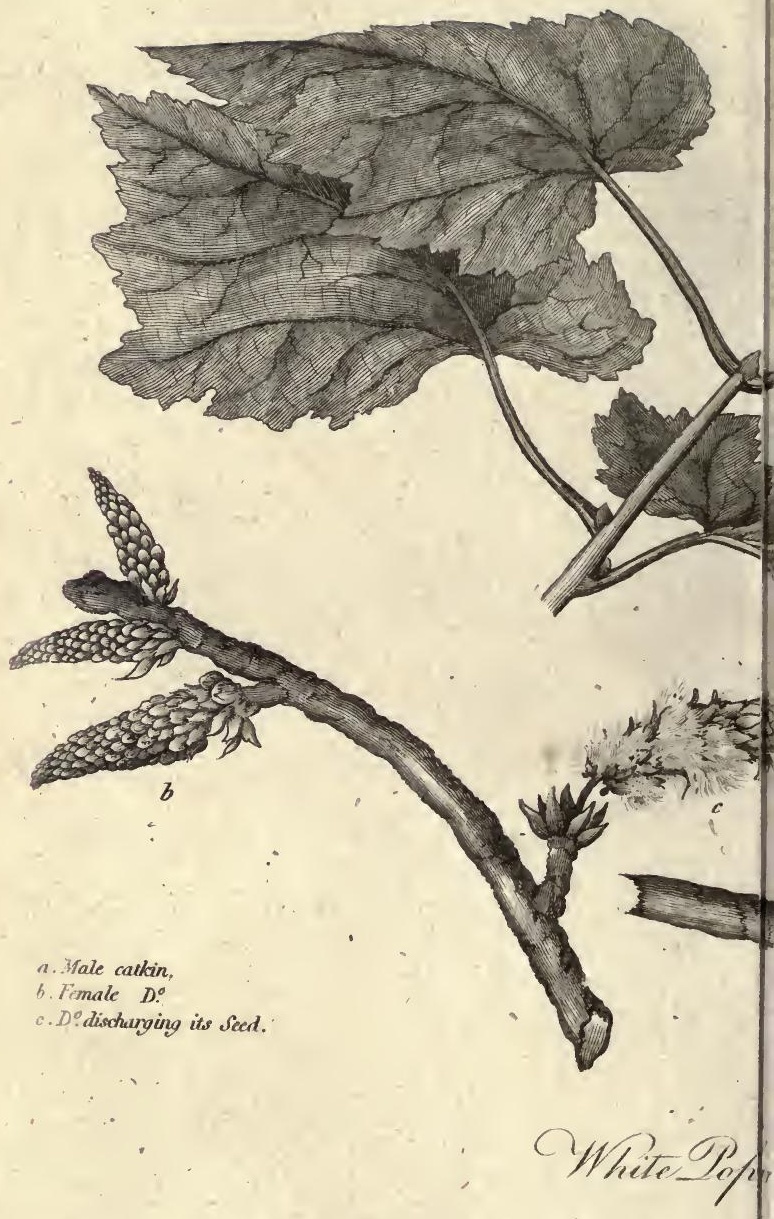




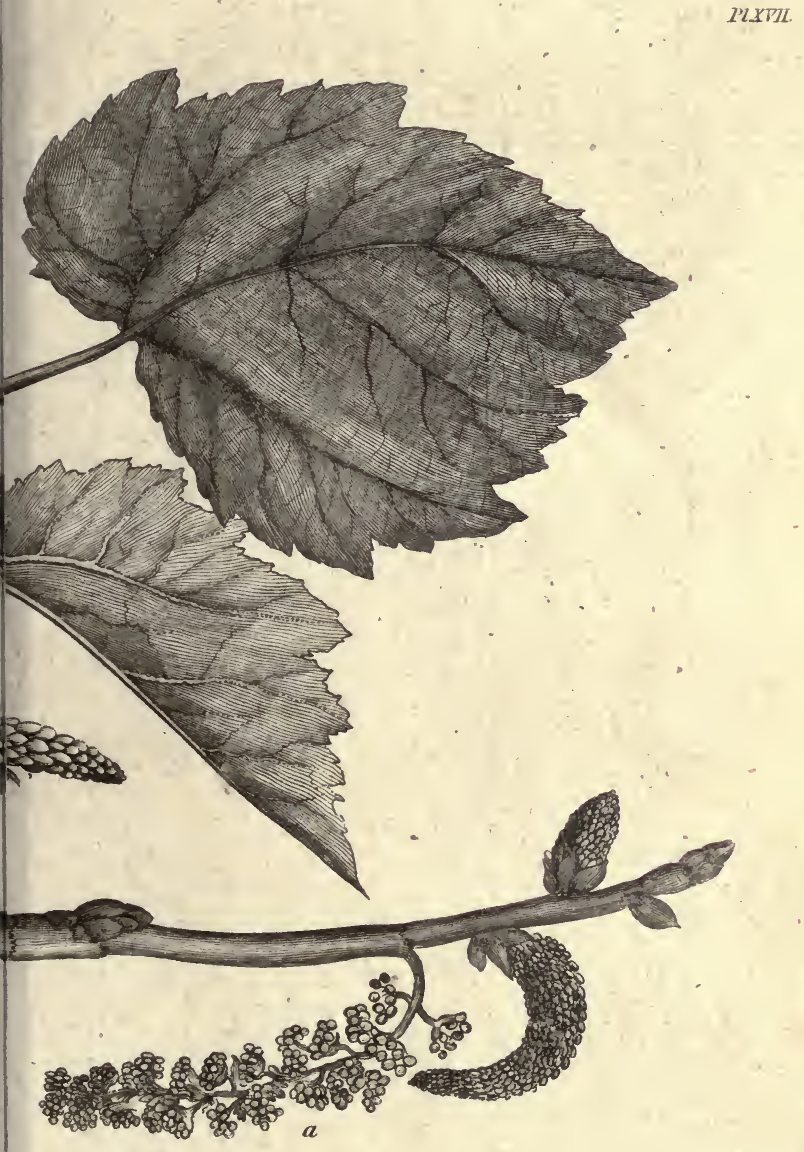




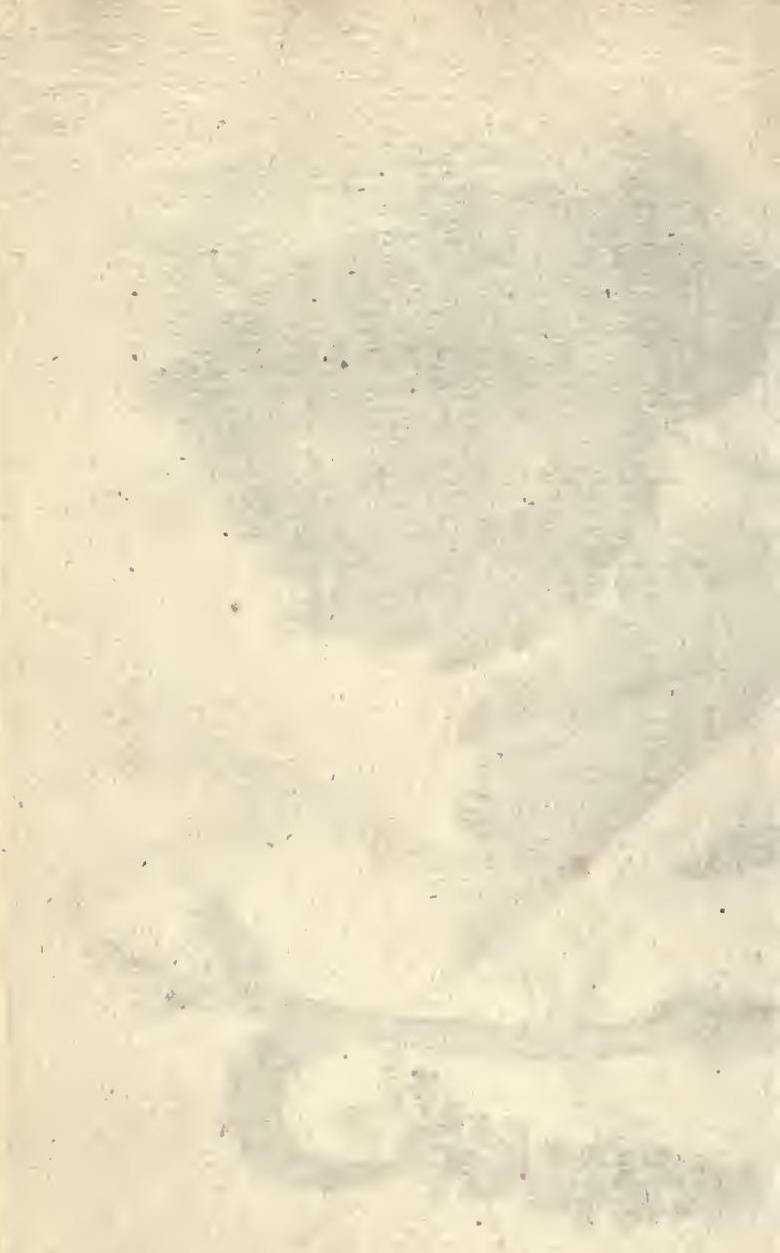




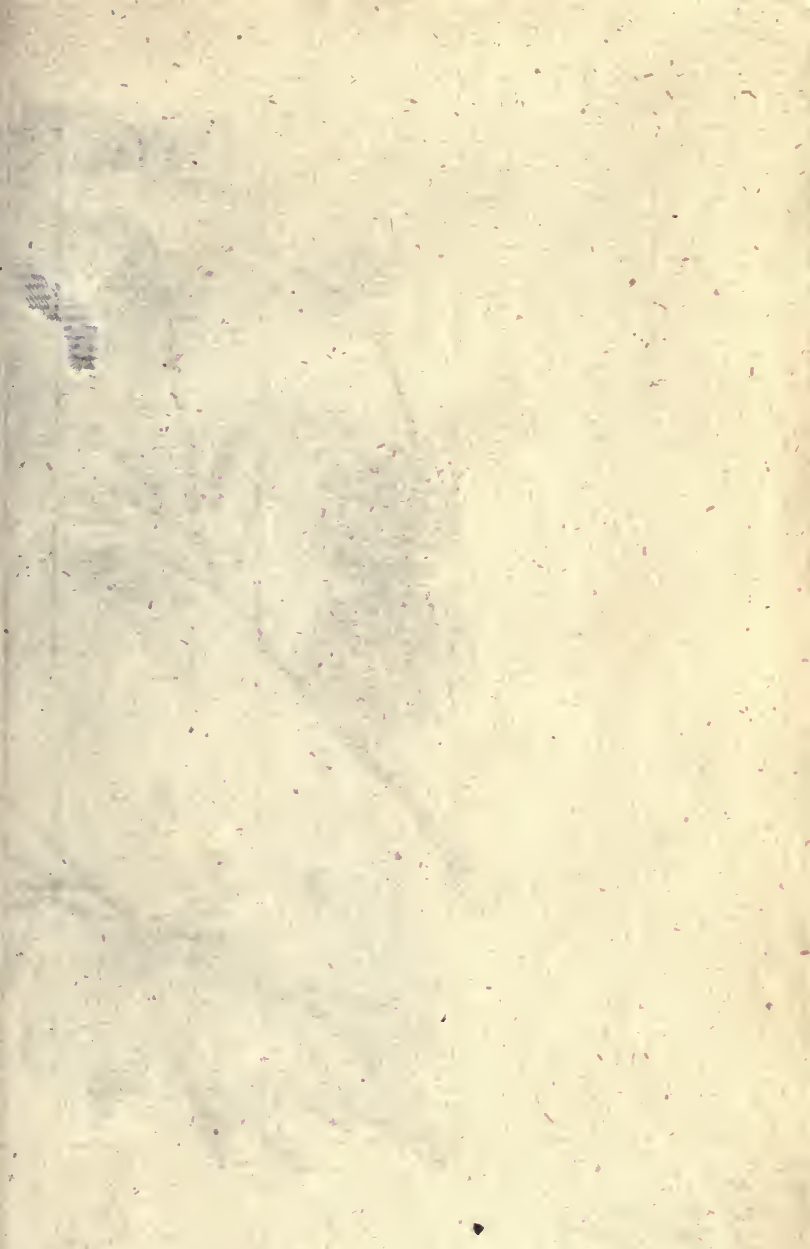




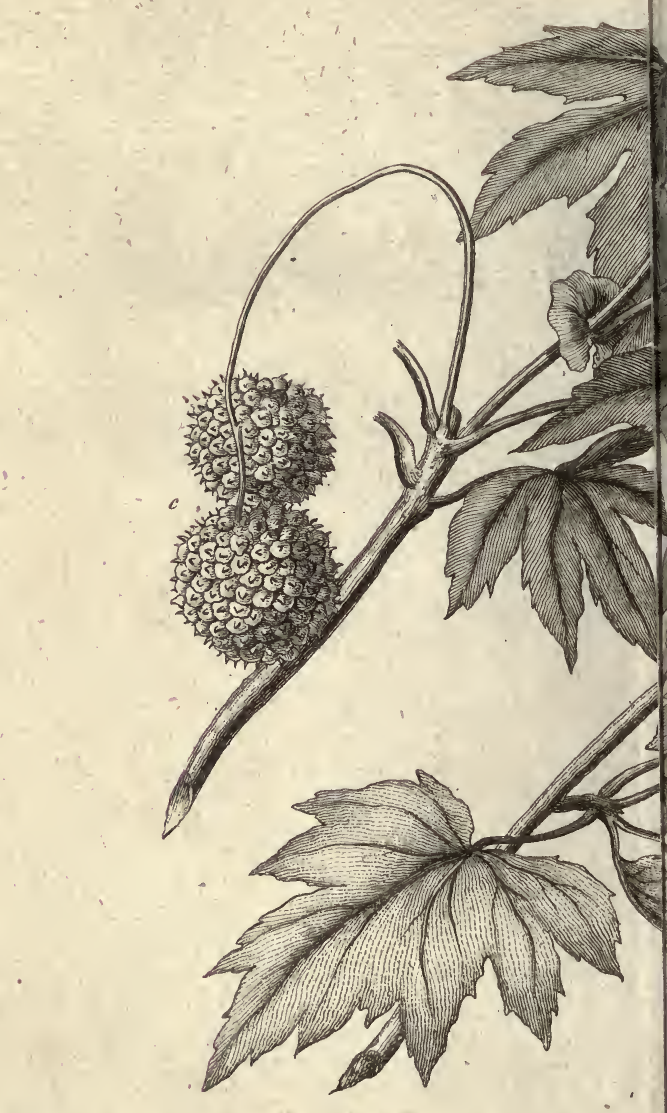

a. Male oatkin.

b. Female $D^{\circ}$

c. Globe or Sceds. 


\section{PLXVII}

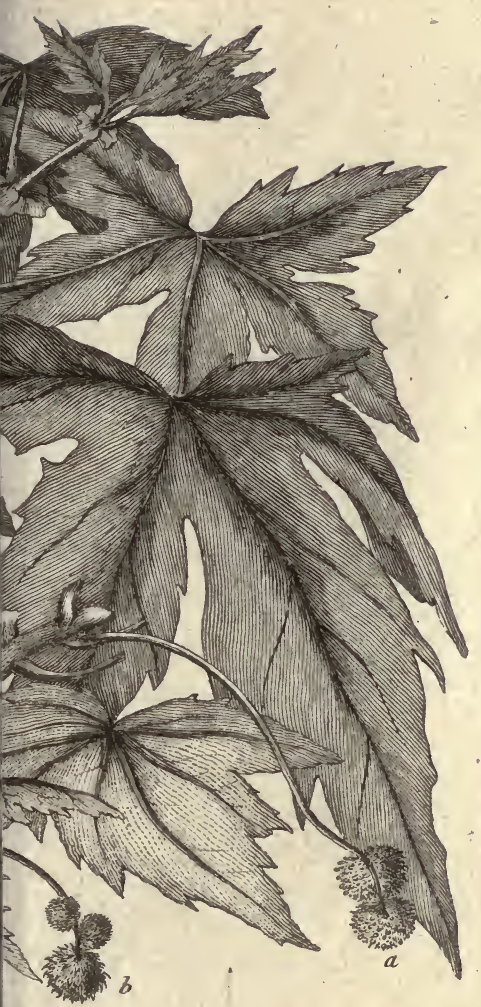





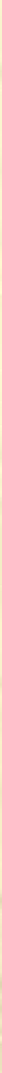




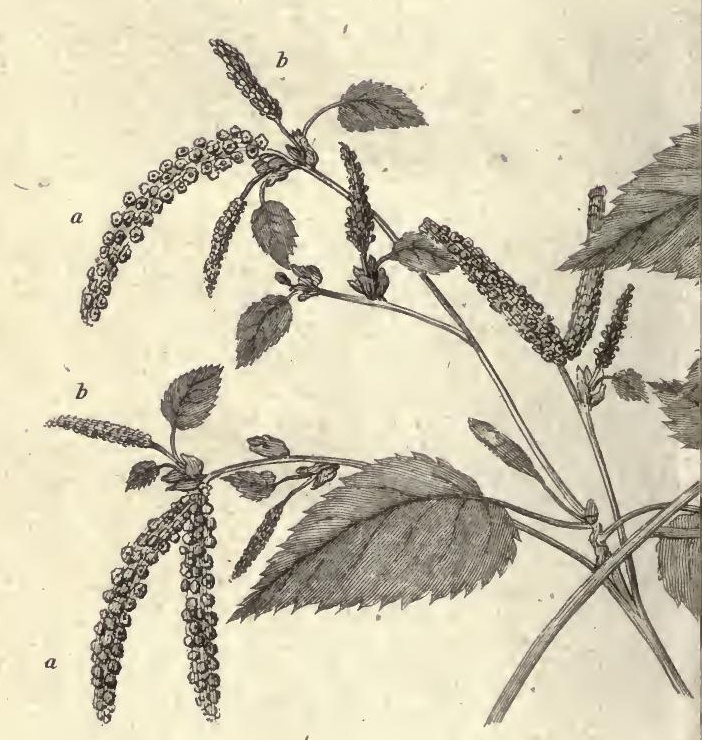




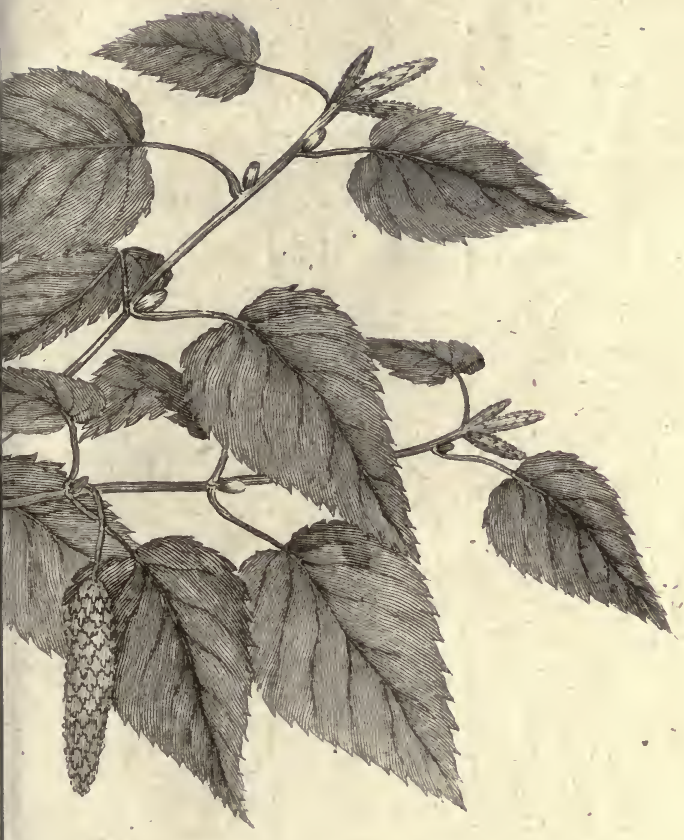

11

a. Male aukin

h. Fomale 1 ?

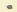

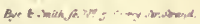




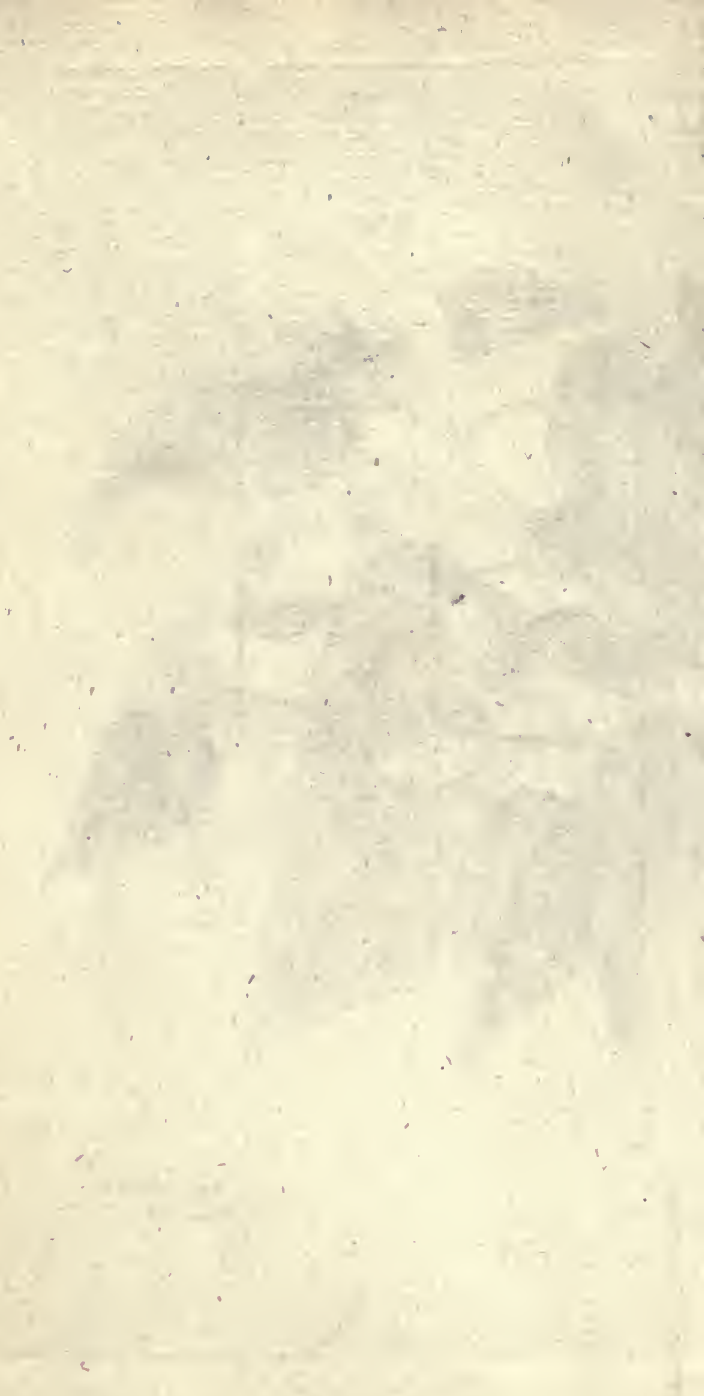





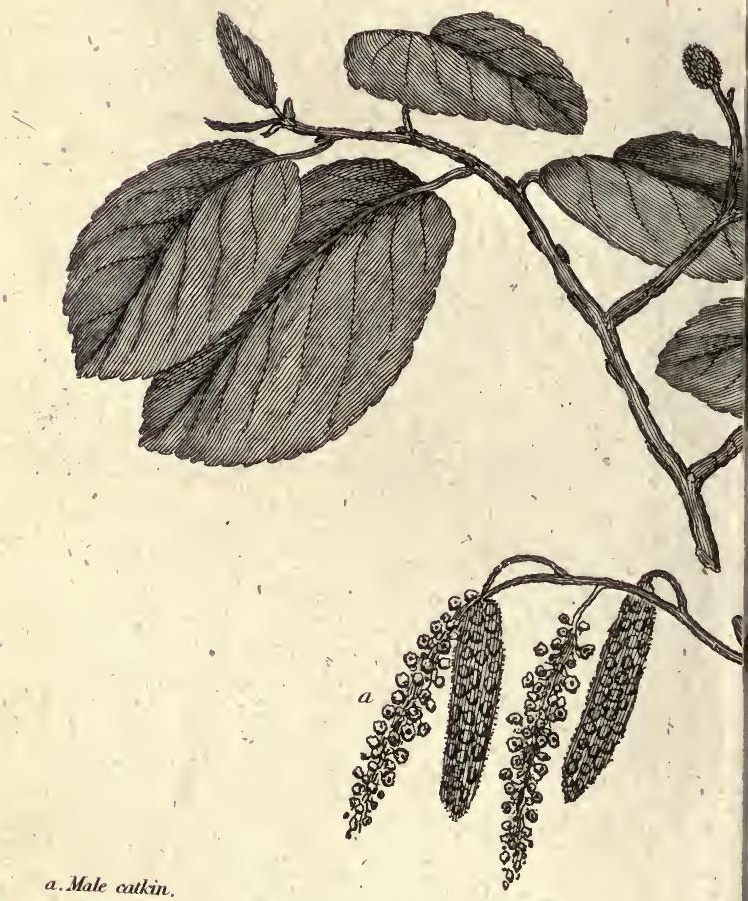

b. Female $D$.

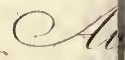




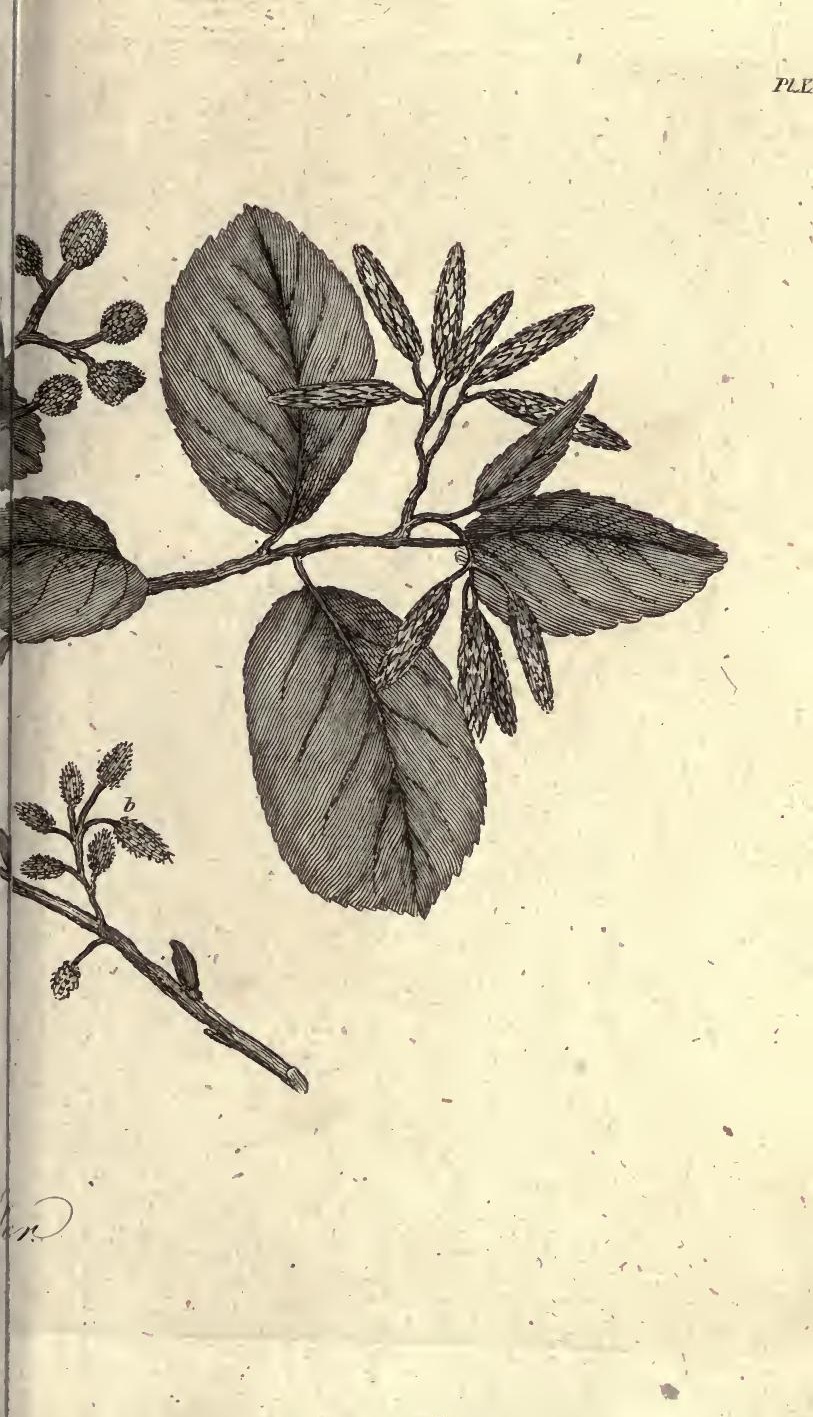





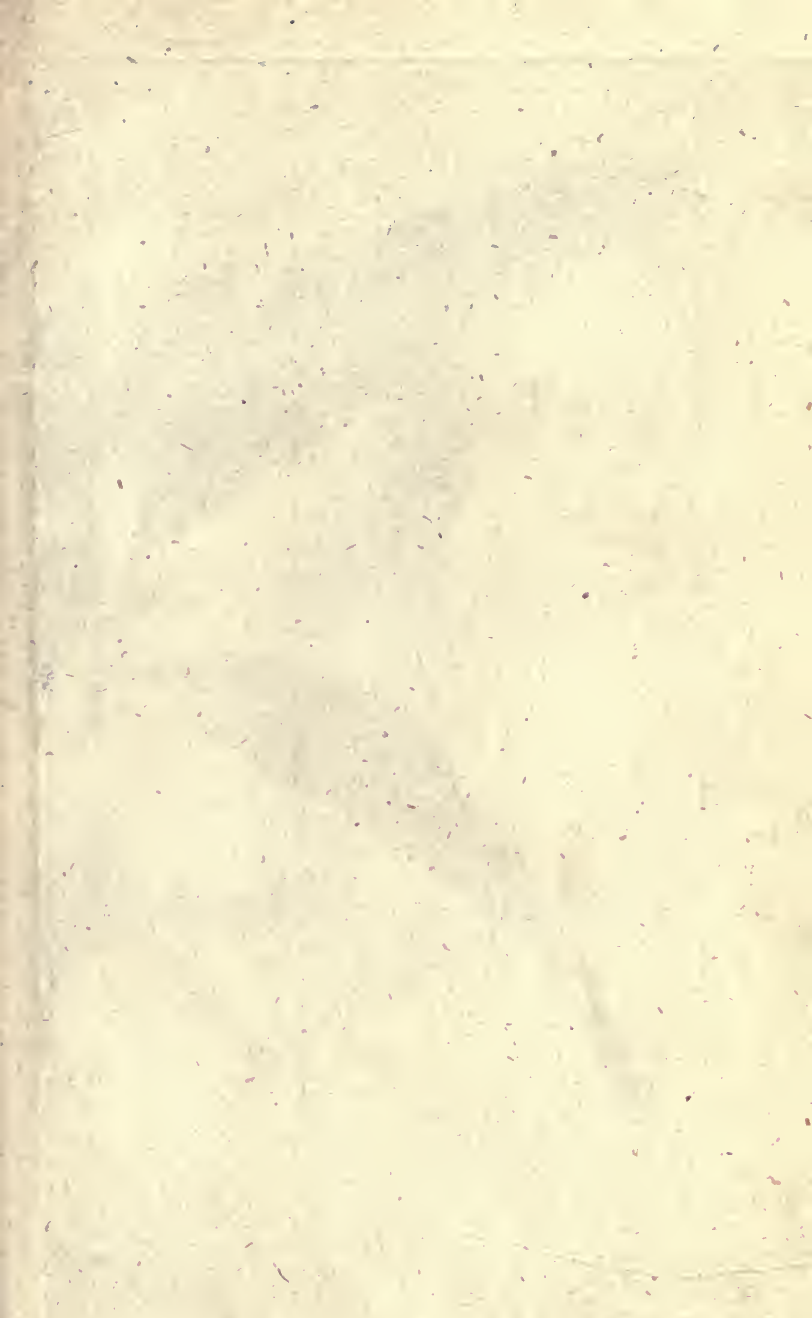





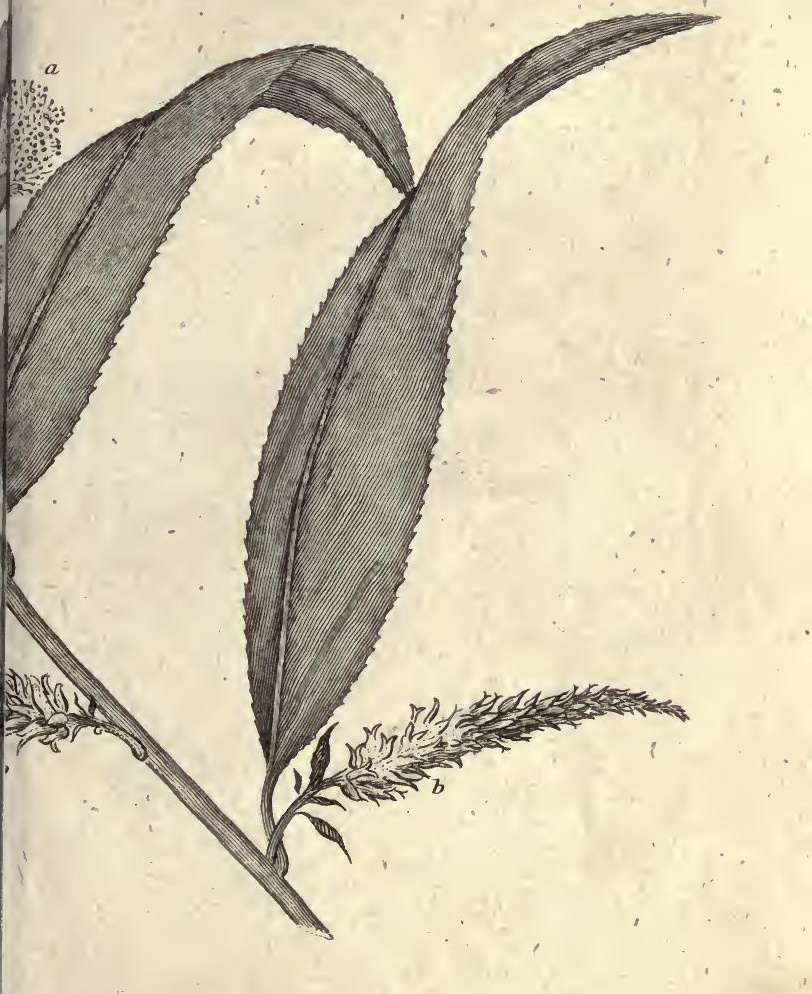

How

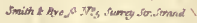



I

i.

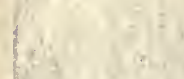

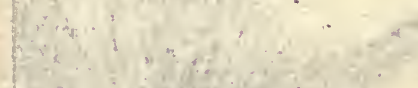

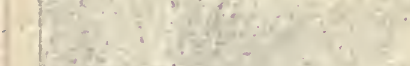

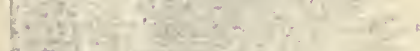

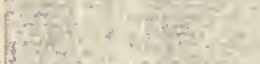

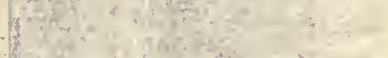

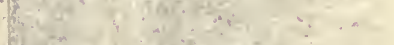

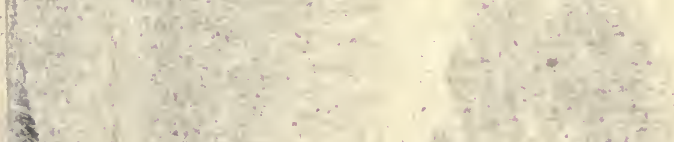

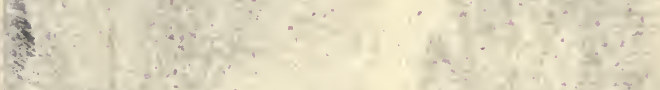

1,06

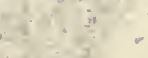

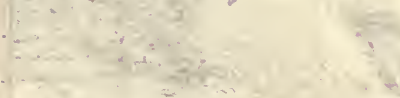
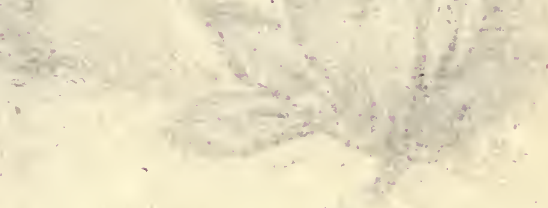

r 


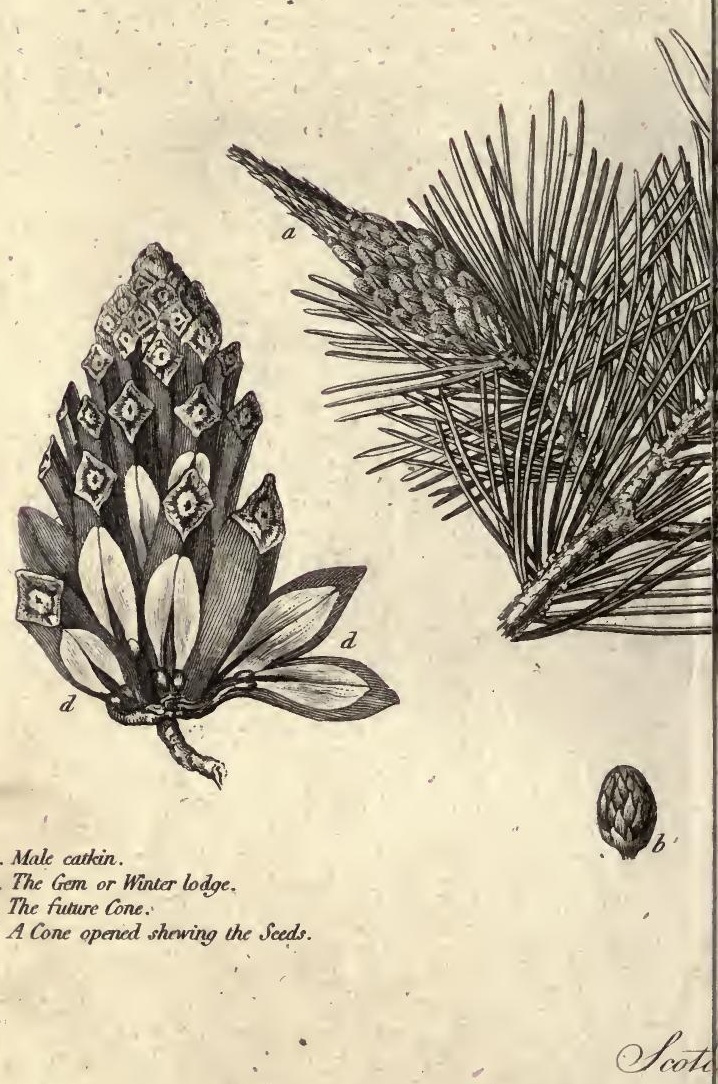




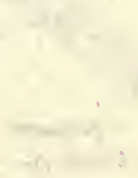


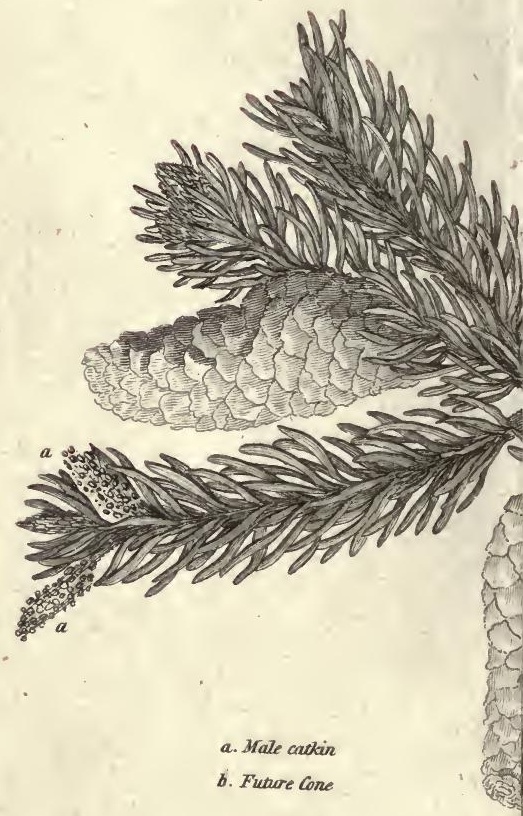



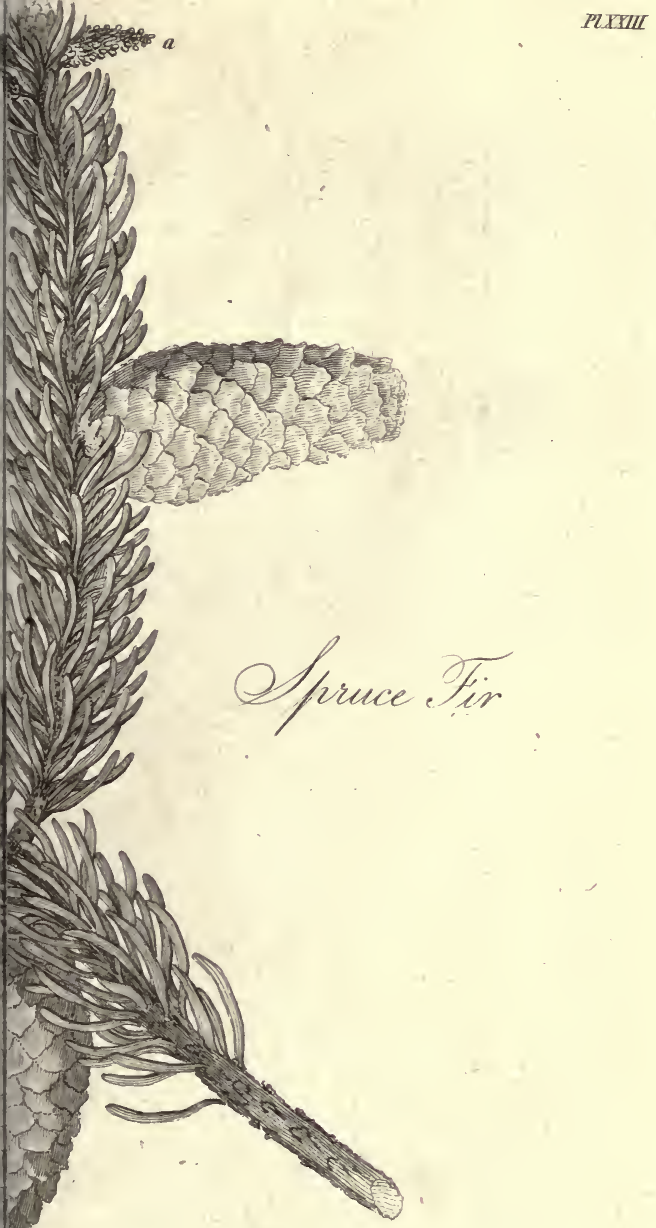

Bye \& smuth sc 



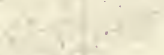




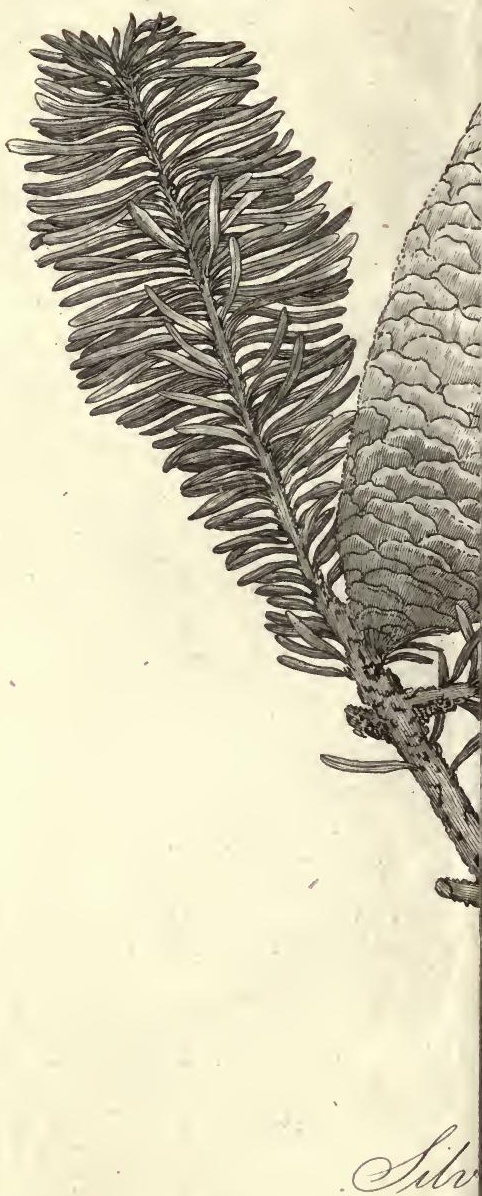




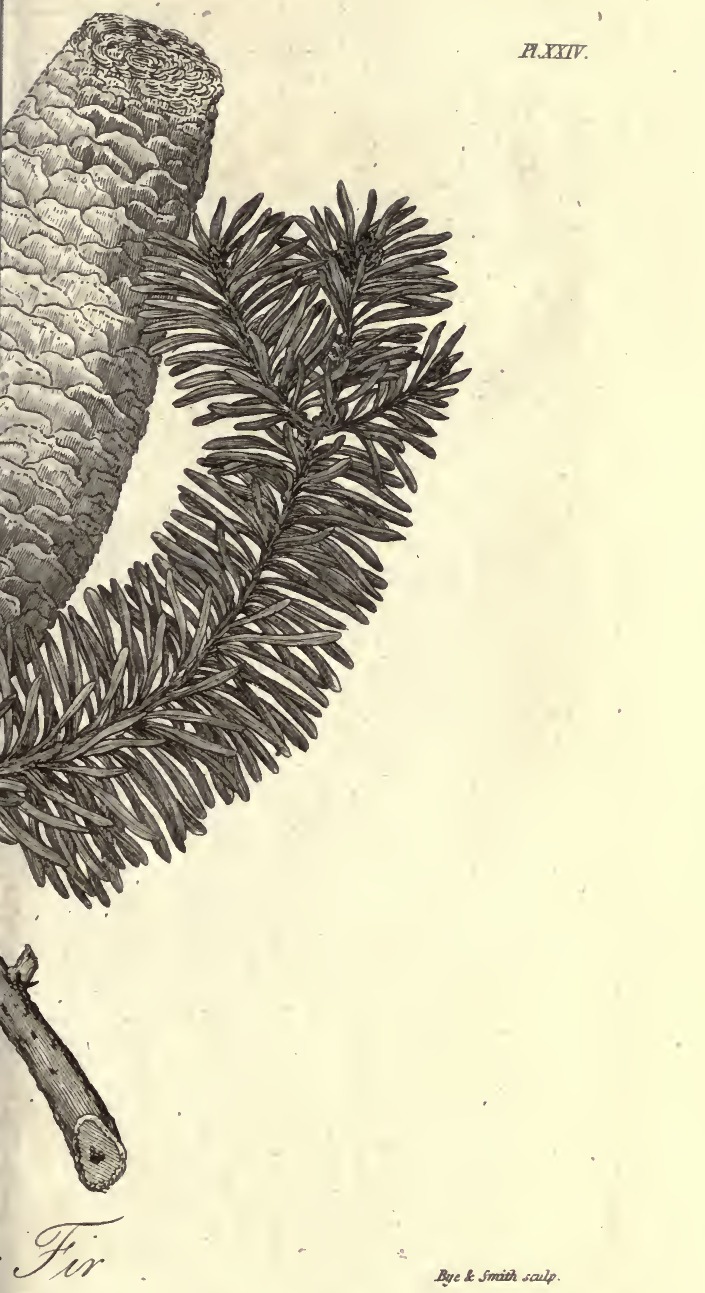



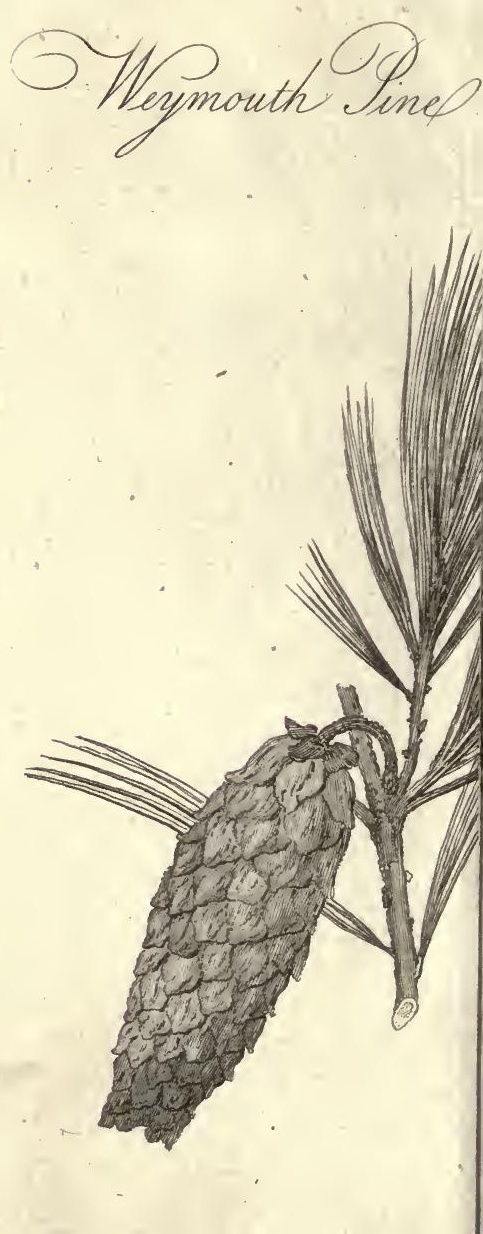


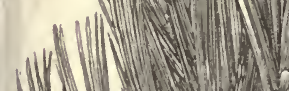

WW

man.

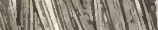

I fum is

N/A

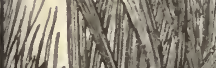

syd

(1)
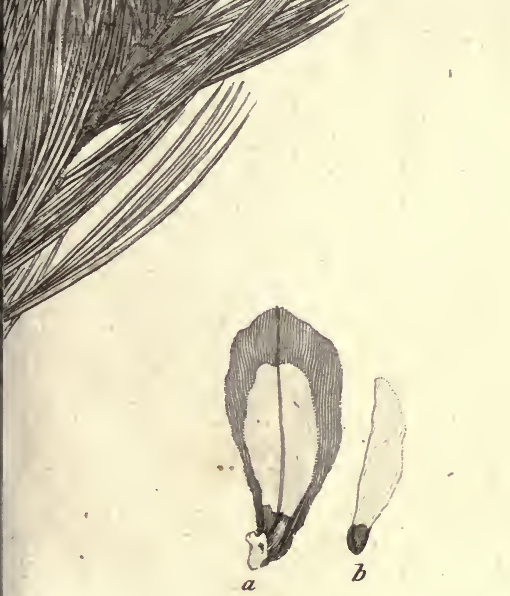

a. Scale with two winged Secds.

b. Simple seed. 


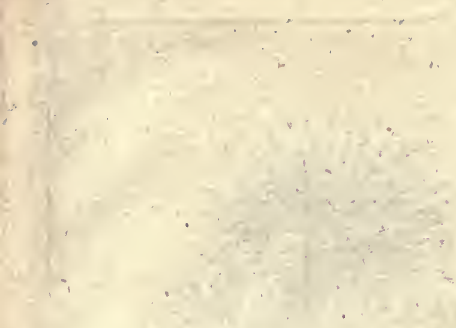

5

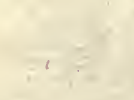

+ 1
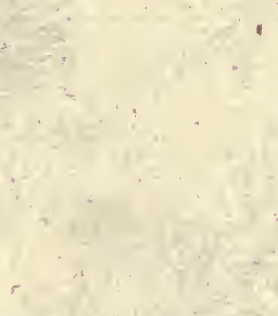


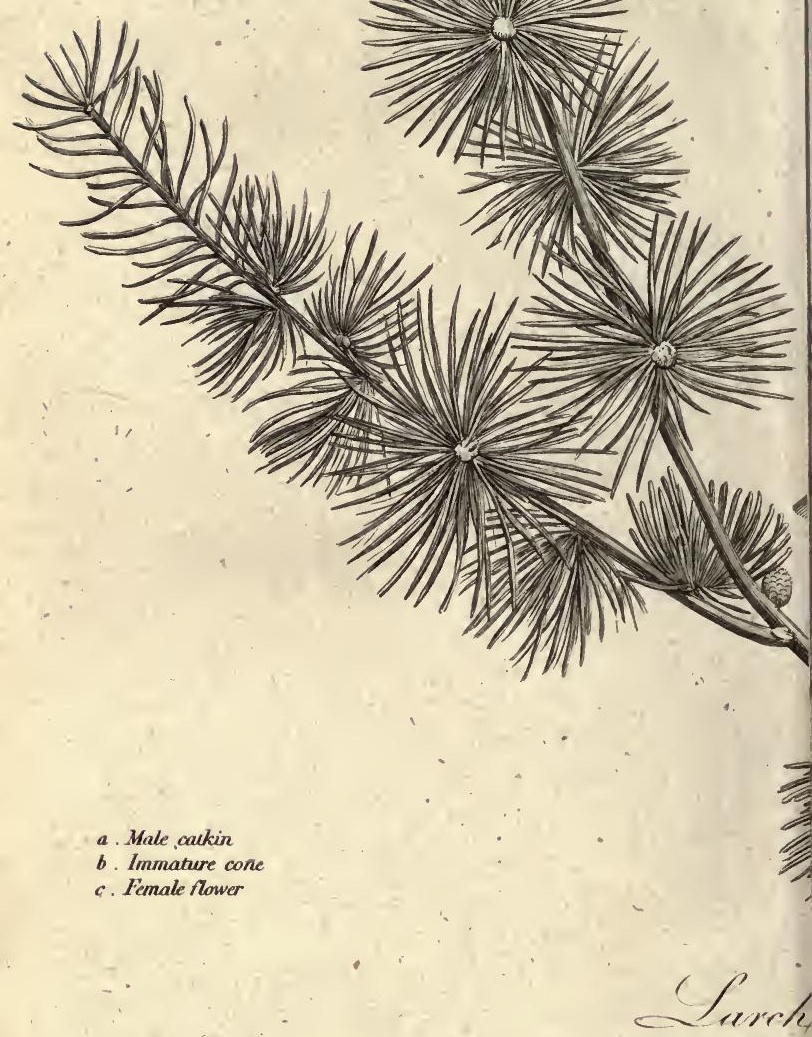






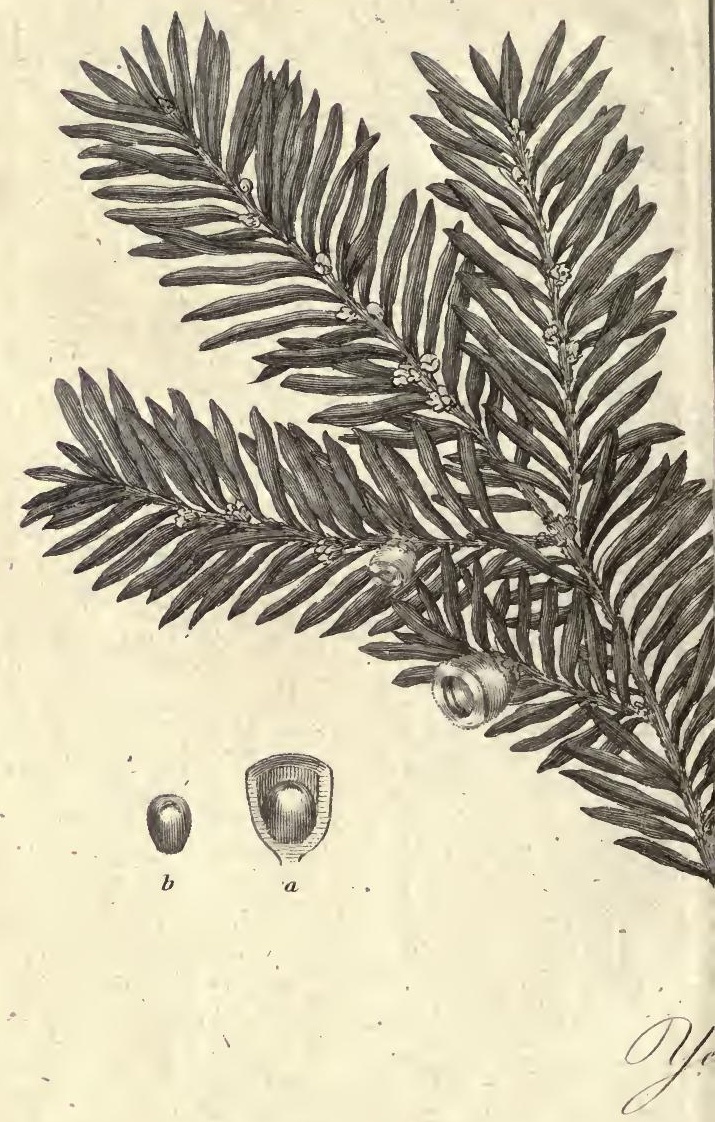


$2=1$

,

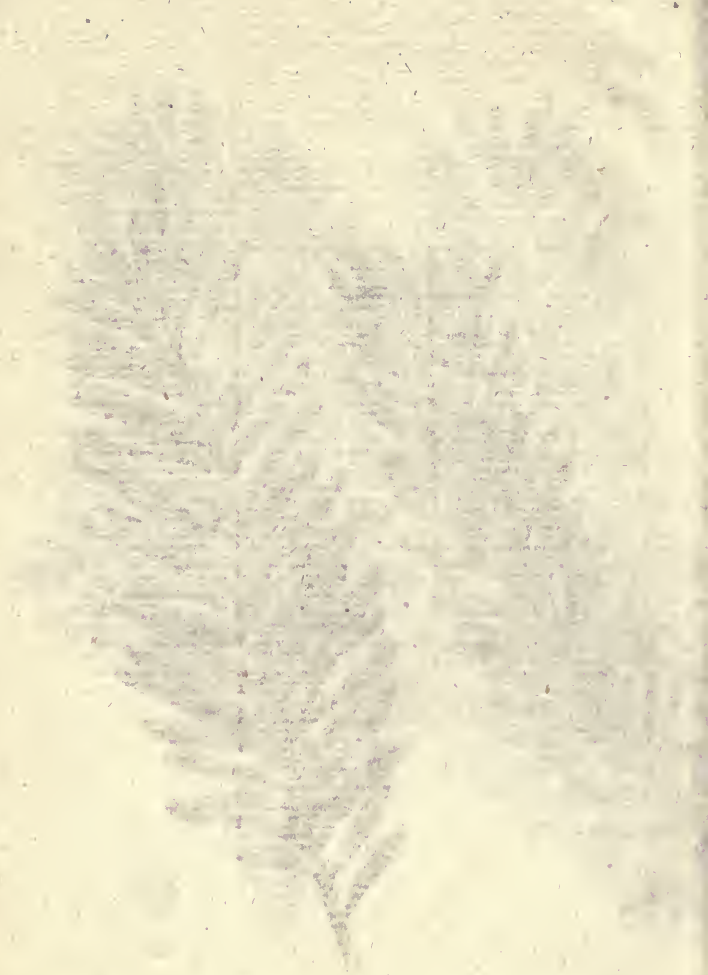


$104+5$

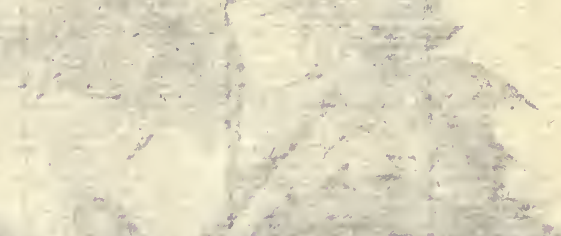

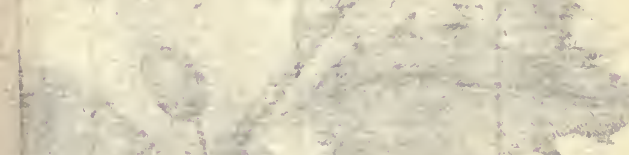

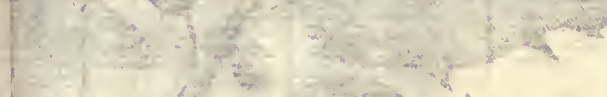

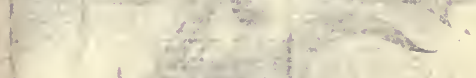

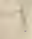

(nt)

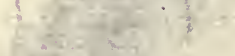

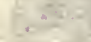

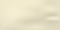

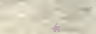

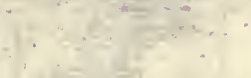

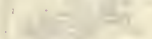

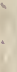

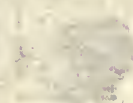

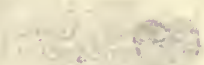

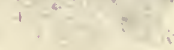

$\therefore \quad ;$

$7-5=$

$-4$

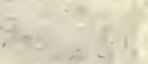

$n^{-}+2=0$
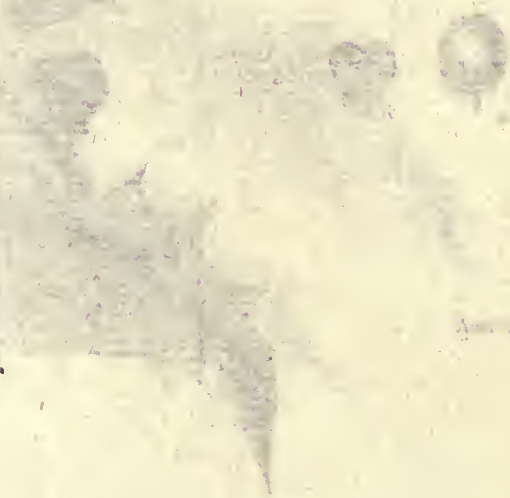


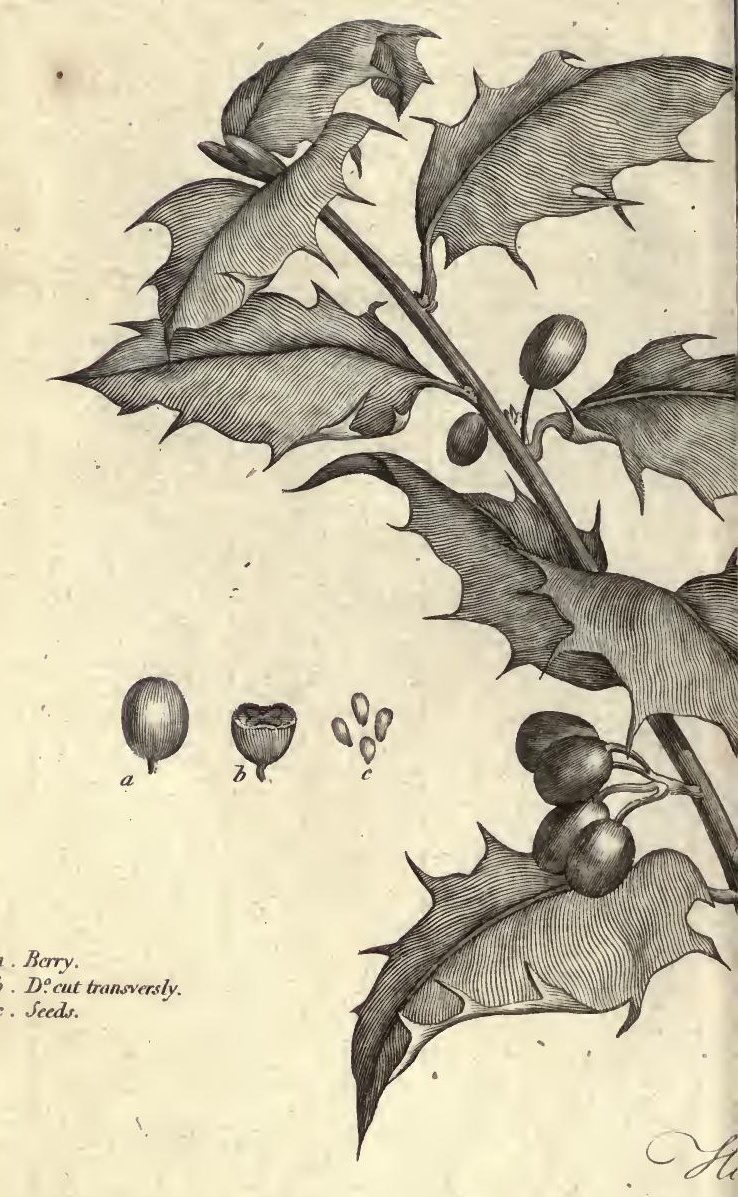




\section{University of California Library Los Angeles}

This book is DUE on the last date stamped below.

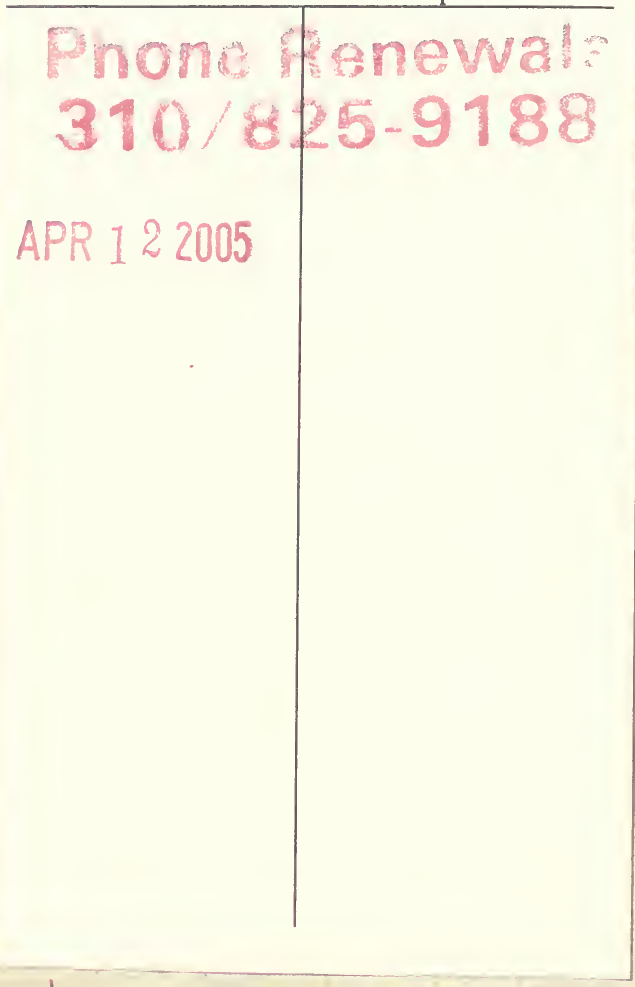




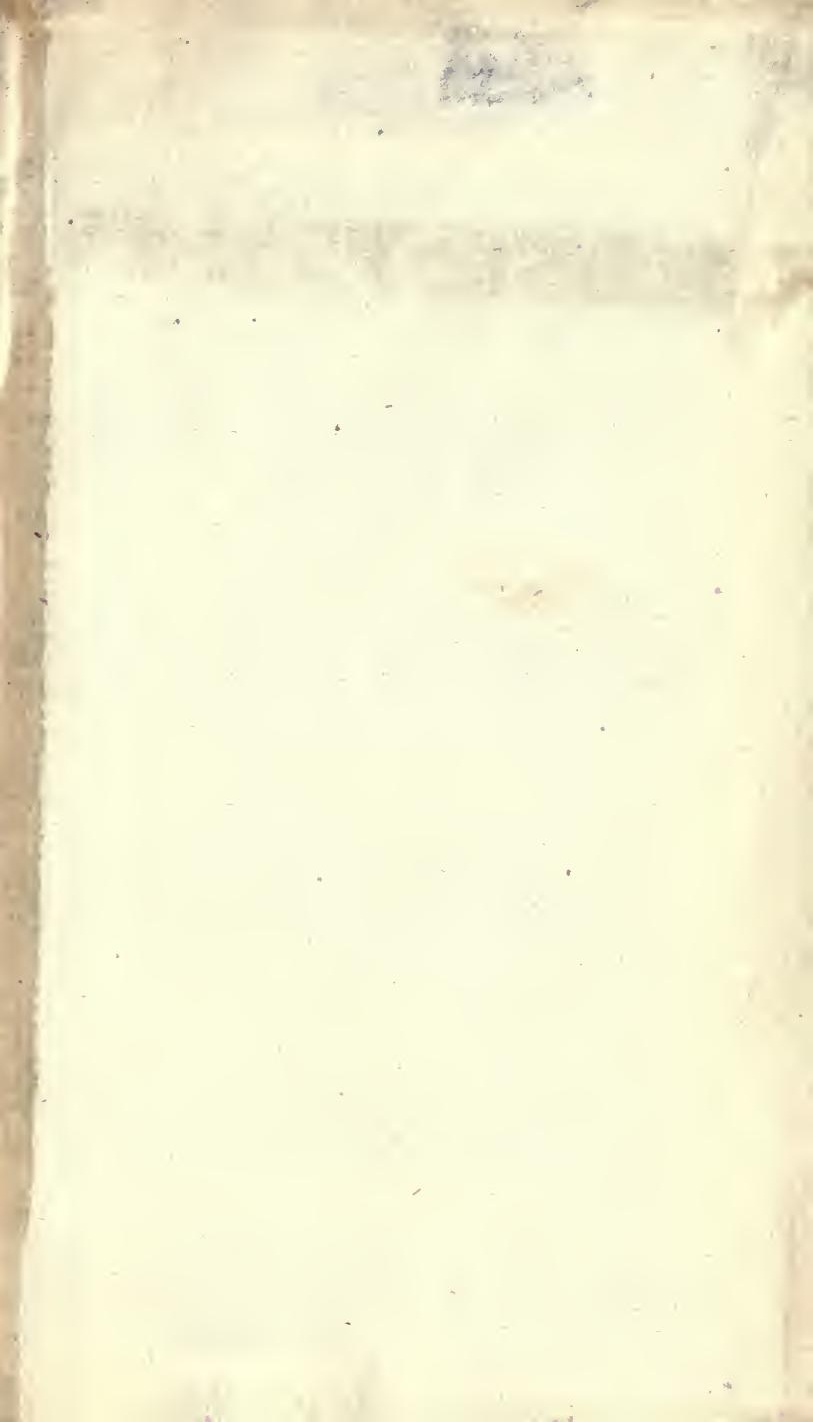


University of California SOUTHERN REGIONAL LIBRARY FACILITY SOUTHERN REGIONAL LIBRARY FACILe 951388
305 De Nave Drive - Parking Lot 17 - Box
LOS ANGELES, CALIFORNIA 90095-1388 Return this material to the library from which it was borrowed. 



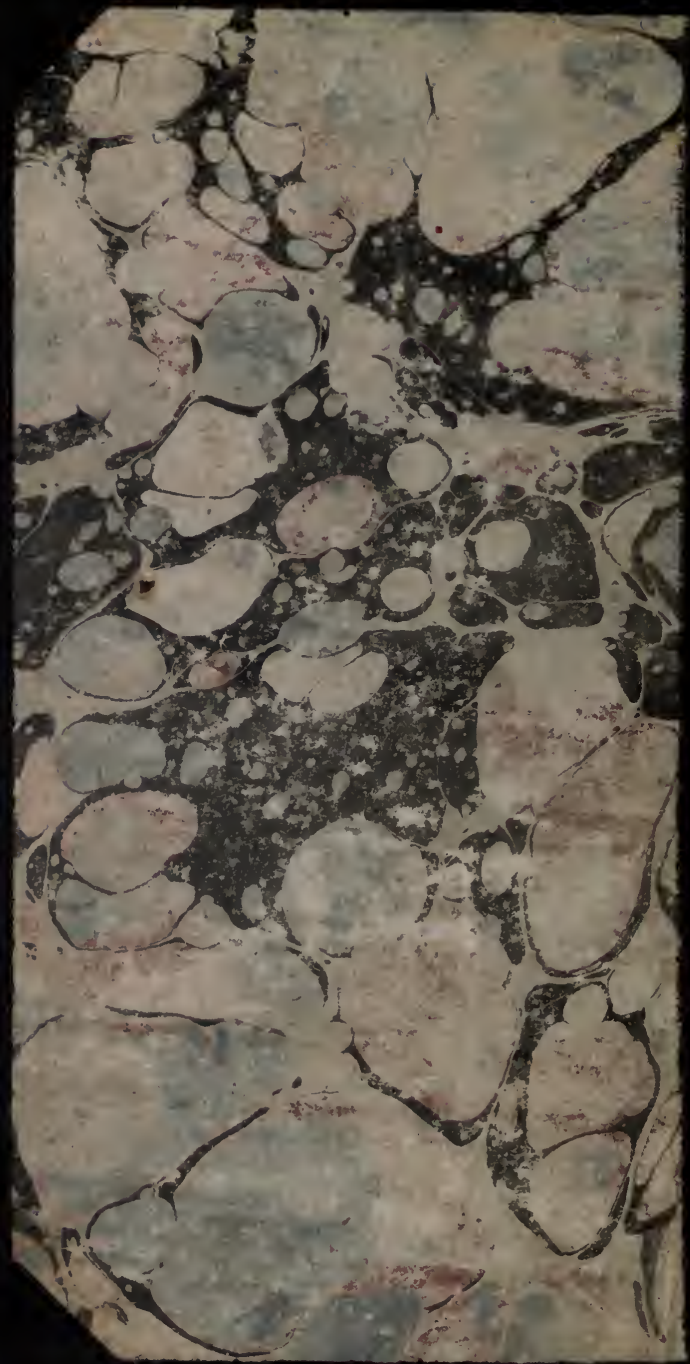

Univer

Sout

Lib 